Fabíola Miotto Maeda

\title{
PRESTAÇÃO DE SERVIÇO POR MEIO DE PESSOA JURÍDICA: DIGNIDADE E FRAUDE NAS RELAÇÕES DE TRABALHO.
}

\author{
Dissertação de Mestrado \\ Departamento de Direito do Trabalho e da Seguridade Social.
}

Orientador: Prof. Dr. Otavio Pinto e Silva

Faculdade de Direito da Universidade de São Paulo.

São Paulo

2014 
Fabíola Miotto Maeda

\section{PRESTAÇÃO DE SERVIÇO POR MEIO DE PESSOA JURÍDICA: DIGNIDADE E FRAUDE NAS RELAÇÕES DE TRABALHO.}

Dissertação apresentada à Banca Examinadora da Faculdade de Direito da Universidade de São Paulo, como exigência parcial para obtenção do título de Mestre em Direito do Trabalho e Seguridade Social.

Orientador: Professor Dr. Otavio Pinto e Silva.

Área de concentração: Direito do Trabalho e Seguridade Social.

Faculdade de Direito da Universidade de São Paulo.

São Paulo 
Banca Examinadora 
Este trabalho é dedicado ao meu pai e à minha mãe, que sempre, com muito amor e dedicação, estiveram ao meu lado em cada passo, me orientando e apoiando e aos quais devo todas as conquistas alcançadas. Também é dedicado ao meu marido pelo apoio, amizade, paciência e compreensão e à minha irmã, minha melhor amiga. 


\section{AGRADECIMENTOS.}

Ao Professor Otavio Pinto e Silva, meu orientador, por toda a ajuda ao longo do curso, pelas conversas e reuniões que se mostraram fundamentais para a condução do presente trabalho e para o meu crescimento profissional.

Aos Professores Nelson Mannrich e Ari Possidonio Beltran pelas críticas e sugestões deduzidas no exame de qualificação e pela ajuda em minha pesquisa bibliográfica.

Aos meus pais, pelo carinho de sempre, pelo incentivo e apoio em todos os momentos.

Ao meu marido, pela paciência, pela compreensão, pelo companheirismo nos momentos alegres e difíceis.

À minha irmã e meu cunhado Eduardo, amigos especiais, ainda que a distância não nos permita encontros frequentes.

À minha madrinha, Marlene, à minha tia Vera e tio Pedro, aos quais tenho grande carinho. 


\section{RESUMO}

As alterações nas formas de produção e e nas formas de organização do trabalho ensejaram uma diversificação das modalidades contratuais, fomentando o trabalho autônomo. Em alguns países europeus, reconheceu-se a figura do trabalhador situado em uma zona intermediária entre o trabalho subordinado e o autônomo, denominado trabalhador parassubordinado (Itália), trabalhador economicamente dependente (Espanha).

No Brasil, a omissão da legislação associada às exigências de um sistema produtivo cada vez mais dinâmico e competitivo incentivam uma releitura do Direito do Trabalho para que este amplie seu âmbito de incidência e garanta a um maior número de trabalhadores um trabalho decente e o respeito à sua dignidade.

O mercado de trabalho exige que o trabalhador se qualifique, o que lhe confere maior autonomia no desenvolvimento de suas atividades. Trabalhadores intelectuais altamente especializados acabam prestando serviços de maneira autônoma ou parassubordinada, excluídos, atualmente, de qualquer proteção trabalhista. Muitas vezes, pressionados pelos encargos tributários, constituem pessoa jurídica para a prestação de serviços, o que veio a ser regulado pelo art. 129, da Lei 11.196/2005. O presente trabalho estuda esta prática que afeta diretamente o Direito do Trabalho e, não raramente, é utilizada para burlar a aplicação desta legislação. Nestas situações, a fraude trabalhista se revela como um perverso instrumento a desconsiderar o trabalhador como ser humano. Através da análise das disposições legais e da jurisprudência, procurar-se-á demonstrar as situações em que a constituição de pessoa jurídica para a prestação de serviços intelectuais é lícita e em quais momentos assume objetivos escusos.

Palavras chave: parassubordinação, trabalho decente, Lei 11.196/2005, fraude. 


\section{ABSTRACT}

Recent changes in the way of production and in the labor organization led to diverse forms of contractual arrangements, encouraging self-employment. In some European countries, was recognized the worker located in a gray area between subordinate employment and self-employment, named para-subordinate work (Italy) or economically dependent work (Spain).

In Brazil, the absence of legal texts connected with the needs of a dynamic and competitive production process encourage a new interpretation of Labor Law for an expansion of its ambit of application ensuring a decent work and respect to dignity for more workers

The needs of labor market demands skilled worker, that have more autonomy to do their tasks. Intellectual workers act in a self-employment or in a parasubordinate way, nowadays, without legal protection. Often, because of the tax responsibilities, create legal entity regulated by Law 11.196/2005 (article 129). This work studies this reality that affects the Labor Law and, nor rarely, is used how an intentional dissimulation of employment relationship. In these cases, the fraud is perverse because do not regard the worker as a human being. This work will try to show when the creation of legal entity is lawful or not, through the study of the legislation and the decisions of Courts.

Key words: para-subordinate work, decent work, Law 11.196/2005, fraud. 


\section{LISTA DE SIGLAS E ABREVIATURAS}

ART.: artigo

CC: Código Civil

CF: Constituição Federal.

CLT: Consolidação das Leis do Trabalho.

COSIT: Coordenação Geral de Tributação, da Secretaria da Receita Federal.

CPC: Código de Processo Civil

CTN: Código Tributário Nacional

EIRELI: Empresa Individual de Responsabilidade Limitada

ESMAT 13: Escola Superior da Magistratura Trabalhista da Paraíba.

FGTS: Fundo de Garantia por Tempo de Serviço.

MEIs: microempreendedores individuais.

OIT: Organização Internacional do Trabalho.

TRT: Tribunal Regional do Trabalho.

TST: Tribunal Superior do Trabalho. 


\section{Sumário}

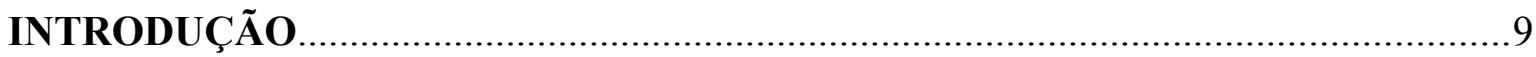

CAPÍTULO 1 - AS TRANSFORMAÇÕES NO MUNDO DO TRABALHO. 13

1.1. Breves considerações sobre as alterações na forma de produção e seus impactos nas relações de trabalho.

1.2. Da flexissegurança.

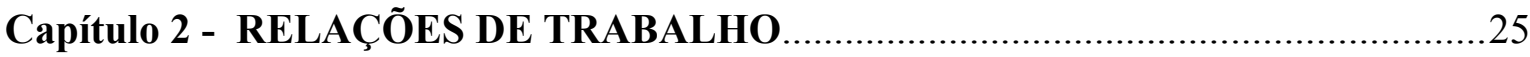

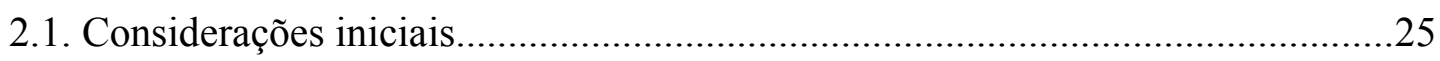

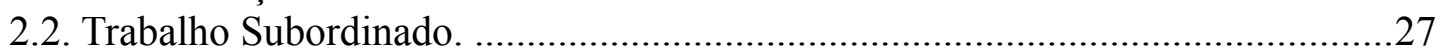

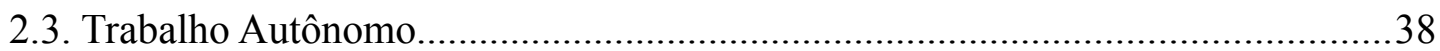

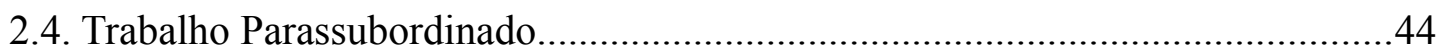

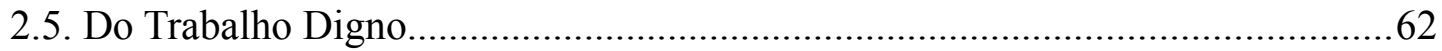

CAPÍTULO 3 - TRABALHO PRESTADO POR PESSOAS JURÍDICAS..................75

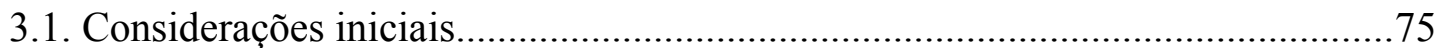

3.2. O artigo 129, da Lei 11.196/2005 ................................................................. 77

3.2.1. Da existência de um contrato de prestação de serviços de natureza intelectual

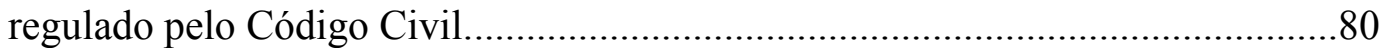

3.2.2. Considerações sobre a forma societária, antes do advento da Lei 12.441/2011.

3.2.3. Considerações sobre a forma societária, após o advento da Lei.

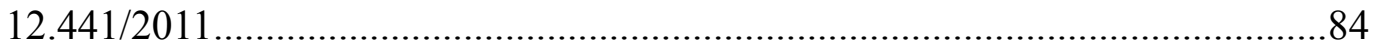

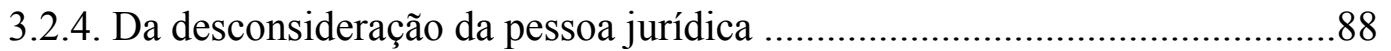

3.3. O art. 129, da Lei 11.196/2005 e o Direito do Trabalho......................................92

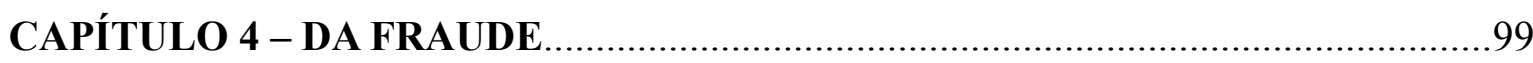

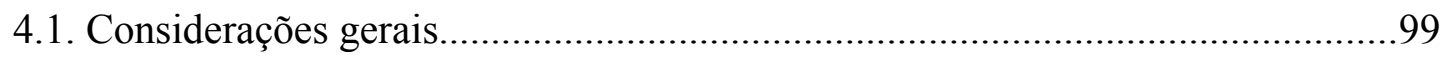

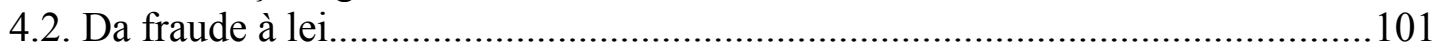

4.3. Distinções entre fraude e demais vícios do negócio jurídico.............................108

4.4. Fraude no Direito do Trabalho.........................................................................112

4.5. Da fraude mediante contratação do trabalhador por meio de constituição de pessoa jurídica.

CONCLUSÃO

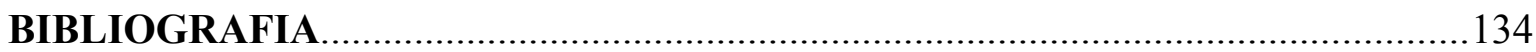




\section{INTRODUÇÃO}

A realidade fática que fundamentou o surgimento do Direito do Trabalho se alterou profundamente em razão do avanço tecnológico, da globalização e das mudanças no modo de produção capitalista. As empresas diminuíram de tamanho e descentralizaram sua produção. A mecanização e a robotização substituíram o homem em várias etapas do processo de fabricação. Por outro lado, vivenciou-se o desenvolvimento do setor terciário e o aparecimento de novas profissões.

O mercado passou a valorizar o trabalhador qualificado, especializado, ao mesmo tempo em que começou a adotar outras formas de contratação, mais flexíveis e dinâmicas. Embora o trabalho subordinado ainda constitua meio importante de contratação, verifica-se o crescimento do trabalho autônomo e parassubordinado, incentivando uma adaptação do Direito do Trabalho brasileiro ao novo contexto social e econômico.

Muitos trabalhos intelectuais especializados são prestados de maneira autônoma ou parassubordinada, excluídos, atualmente, de qualquer tutela trabalhista. Seja em razão do sucesso da atividade desenvolvida, seja por razões de ordem tributária, opta-se pela criação de pessoa jurídica para a prestação de serviços intelectuais. A Lei 11.196/2005, em seu artigo 129, assumindo um caráter notadamente fiscal, regulou esta situação visando proporcionar maior segurança àqueles que decidem criar uma pessoa jurídica.

Ao mesmo tempo em que a constituição de pessoa jurídica para a prestação de serviços intelectuais se mostra amparada pelo princípio constitucional da livre iniciativa (art. 170, caput, da CF) eis que melhor adequada às necessidades de um mercado mais dinâmico, pode, também, ser utilizada como forma de burlar a aplicação da legislação trabalhista ao camuflar uma verdadeira relação de emprego. O presente trabalho tem como escopo analisar estas duas situações além de refletir sobre a possibilidade de o Direito do Trabalho brasileiro abranger este novo contingente de trabalhadores, pessoas físicas que, sem organização empresarial, desempenham suas atividades com autonomia ou mesmo apresentando certa relação de coordenação com os fins almejados pelo tomador de serviços, mas que estão desamparados pela legislação trabalhista.

A importância do tema se revela por sua atualidade, pelo fato de a 
constituição de pessoa jurídica para a prestação de serviços intelectuais ser uma prática difundida na sociedade, utilizada adequadamente ou não. Há um número expressivo de ações propostas perante a Justiça do Trabalho visando o reconhecimento do vínculo trabalhista sendo que nem sempre a fraude resta demonstrada. No entanto, uma vez apurada, a fraude trabalhista se mostra reprovável e deve ser duramente combatida, já que faz do trabalhador uma coisa, violando sua dignidade.

Por outro lado, o momento vivenciado exige uma releitura do Direito do Trabalho para que este traga ao seu âmbito de proteção um maior número de trabalhadores, ainda que conferindo a estes um grau diferenciado de tutela.

Inicialmente, será feita uma análise de questões mais amplas para, depois, serem abordadas as particularidades do tema.

No Capítulo 1, serão consideradas as transformações no mundo do trabalho. Em linhas gerais, estuda-se a crise econômica dos anos 70 que promoveu uma reorganização do capital. O modo de produção passou a se mostrar plural, não mais se limitando a uma forma de relação de trabalho. Todas as mudanças ensejaram o debate pela flexibilização das normas trabalhistas, que deve ser entendida como a compatibilização do Direito do Trabalho à nova realidade, sem que isto signifique um retrocesso das conquistas já consolidadas. Importante não identificar flexibilização com desregulamentação ou precarização das relações de trabalho. Diante de alguns efeitos desfavoráveis desencadeados por medidas de flexibilização que se realizaram apenas às custas dos trabalhadores, surgiu, na Europa, uma tentativa de se conciliar flexibilidade e segurança denominada flexissegurança. Através dela, busca-se uma segurança na empregabilidade, mediante o incentivo à aprendizagem e qualificação durante a vida do trabalhador.

O Capítulo 2 volta-se à análise das relações de trabalho de uma maneira geral e, especificamente, do trabalho subordinado e autônomo, com a descrição de seus elementos qualificadores. Entre estes dois gêneros ganha destaque o trabalho parassubordinado, que também será objeto de investigação, na medida em que seu surgimento está ligado às transformações no mundo do trabalho descritas no capítulo inicial. Diante da ausência de previsão legal no ordenamento jurídico brasileiro, o estudo será baseado no direito estrangeiro, notadamente italiano.

No desenvolvimento deste segundo capítulo, procurar-se-á demonstrar 
que a regulação do trabalho parassubordinado pelo Direito do Trabalho é não só uma maneira ampliar seu âmbito de incidência, como também representa uma notável medida de acesso a estes trabalhadores a um trabalho decente. Trata-se de um posicionamento corroborado por doutrinadores nacionais e estrangeiros que pregam uma releitura do Direito do Trabalho, defendendo, alguns, inclusive, a extensão de normas trabalhistas, ainda que de uma forma graduada, a todas as manifestações de trabalho autônomo.

Em geral, os trabalhos autônomo e parassubordinado iniciam-se por uma pessoa física que, com o sucesso da atividade ou visando diminuir os encargos fiscais, acaba, posteriormente, constituindo uma pessoa jurídica. No Capítulo 3, será analisada a prestação de serviços por meio de pessoa jurídica, quando envolvido um trabalho intelectual. O foco será o artigo 129, da Lei 11.196/2005 cujo objetivo foi proporcionar segurança aos profissionais que optam por esta forma de realização de suas atividades. Trata-se de trabalhadores altamente qualificados, especializados, que se caracterizam como autônomos ou parassubordinados. A constituição de pessoa jurídica para a prestação de serviços intelectuais é, em princípio, lícita, eis que amparada pelo princípio da livre iniciativa (art. 170, da Constituição Federal). Além disso, sua adoção representa uma adaptação das relações jurídicas às novas necessidades decorrentes das alterações na forma de produção capitalista e na organização do trabalho.

No entanto, não se desconhece que a criação destas pessoas jurídicas pode ser utilizada como meio de burlar a legislação trabalhista. A fraude será o tema central do Capítulo 4, que se iniciará com algumas considerações gerais sobre este engodo, seu tratamento pela legislação civil e sua distinção em relação a outros vícios do negócio jurídico. A fraude no Direito do Trabalho será estudada em um subitem próprio. A fraude nas relações de trabalho assume diversas configurações e é um mecanismo de mercantilização do trabalho. Suas consequências ultrapassam o campo individual, repercutindo nos âmbitos social e econômico.

No caso específico da criação de pessoas jurídicas para a prestação de serviços, verificou-se que este expediente tornou-se exigência de alguns empregadores para a descaracterização da relação de emprego. Geralmente, envolve trabalhadores mais qualificados, que percebem salários mais altos. Com isto, pretende-se mascarar a relação de emprego através de um contrato de natureza civil/comercial. Esta prática, que passou a 
ser denominada pejotização (neologismo derivado da palavra pessoa jurídica), ganhou destaque nos últimos tempos em diferentes setores econômicos (como áreas hospitalares, informática, indústria de entretenimento etc). É uma forma de precarização das relações de trabalho que pode constituir ilícito penal (art. 203, do Código Penal).

Uma vez demonstrados os requisitos legais para a caracterização da relação de emprego, esta é reconhecida pela Justiça do Trabalho com fundamento no princípio da primazia da realidade, no princípio da imperatividade das normas trabalhistas e no princípio da irrenunciabilidade dos direitos trabalhistas. A fraude, portanto, deve ser comprovada, não podendo ser presumida.

O método utilizado no desenvolvimento do presente trabalho foi o dedutivo, considerando os variados posicionamentos doutrinários e jurisprudenciais a respeito. Elementos da doutrina estrangeira e de diplomas normativos de outros países também foram pesquisados a fim de possibilitar uma visão mais completa sobre o assunto abordado. As citações seguiram as normas da Associação Brasileira de Normas Técnicas ABNT. 


\section{CAPÍTULO 1 - AS TRANSFORMAÇÕES NO MUNDO DO TRABALHO}

\subsection{Breves considerações sobre as alterações na forma de produção e seus impactos nas relações de trabalho.}

Após a $2^{\text {a }}$ Guerra Mundial, houve um grande desenvolvimento do Direito do Trabalho, principalmente nas décadas de 50 e 60, até o início dos anos 70, época marcada pela grande expansão econômica, especialmente nos países da Europa pela presença do Estado de Bem Estar Social (Welfare State), que investia em benefícios sociais. Neste período, a aceleração do processo de acumulação do capital e o ininterrupto crescimento econômico promoveram a consolidação de uma relação salarial estável e homogênea, bem como o funcionamento do mercado de emprego segundo regras uniformes e previsíveis. Essa relação salarial dominante, denominada fordista, se caracterizava pela integração dos trabalhadores na economia capitalista por via do consumo de massa alcançado mediante um crescimento do salário nominal equivalente ao aumento de produtividade. A grande empresa industrial desempenhava papel fundamental neste modelo, colocando-se como a sede da relação de trabalho subordinado. Foi neste contexto que o Direito do Trabalho começou a institucionalizar algumas de suas principais tendências, em um corpo sistemático e coerente ${ }^{1}$.

A década de 70 seria marcada pela crise econômica provocada pelos choques do petróleo (nos anos de 1973 a 1974 e de 1979 a 1980) que levou à desorganização dos mercados, ao agravamento de processo inflacionário em alguns países, ao desemprego e ao aumento do déficit público ${ }^{2}$.

Assim, a partir dos anos 70, o sistema capitalista passou a apresentar os

\footnotetext{
BelTRAN, Ari Possidonio. Direito do Trabalho: crise econômica, flexibilização e desenvolvimento tecnológico. In Empresa e trabalho - estudos em homenagem a Amador Paes de Almeida. Saraiva, 2010, p. 153; REDINHA, Maria Regina Gomes. A relação laboral fragmentada - estudo sobre o trabalho temporário. Boletim da Faculdade de Direito da Universidade de Coimbra, Coimbra editora, 1995, p. 3339 .

2 BELTRAN, Ari Possidonio. Op. cit., p. 153.
} 
sinais de uma crise estrutural, depois de um longo período áureo de acumulação de capitais verificado com o apogeu do fordismo e da fase keynesiana. Os elementos caracterizadores desta crise são delimitados por Ricardo Antunes como sendo: a) queda da taxa de lucro promovida, entre outros elementos, pelo aumento do preço da força de trabalho, conquistado no período pós-45 e pela intensificação das lutas sociais nos anos 60 , que visavam o controle social da produção; b) esgotamento do padrão de acumulação taylorista/fordista de produção, dado pela retração do consumo que se acentuava em razão do desemprego estrutural; c) hipertrofia da esfera financeira, que ganhava relativa autonomia frente aos capitais produtivos; d) maior concentração de capitais graças às fusões entre as empresas monopolistas e oligopolistas; e) crise do Welfare State e a necessidade de diminuição dos gastos públicos e sua transferência para o capital privado; f) incremento acentuado das privatizações, tendência generalizada às desregulamentações e à flexibilização do processo produtivo, dos mercados e da força de trabalho ${ }^{3}$.

A crise deu ensejo a um processo de reorganização do capital identificado pelo advento do neoliberalismo, pela privatização do Estado, pela desregulamentação dos direitos do trabalho, pela desmontagem do setor produtivo estatal e pelo intenso processo de reestruturação da produção e do trabalho. A resposta dada à crise, que pode ser considerada superficial, já que não alterou os pilares essenciais do modo de produção capitalista, promoveu a transição do padrão taylorista e fordista anterior para novas formas de acumulação flexibilizada. Nessa nova fase do capital, o desemprego em dimensão estrutural, a precarização do trabalho de modo ampliado, a destruição da natureza e a não inclusão dos países que não se encontravam no centro da economia capitalista são seus traços característicos ${ }^{4}$.

Foi neste contexto, que o toyotismo e a era da acumulação flexível tiveram início. O toyotismo apresenta, como um de seus elementos caraterísticos, o fato de preservar dentro das empresas matrizes um número reduzido de trabalhadores mais qualificados, multifuncionais e envolvidos com o seu ideário. A contratação flexível de tralhadores é identificada, por exemplo, pelo aumento de horas extras, pela terceirização dentro e fora das empresas e pela contratação de trabalhadores temporários. Quanto mais o

3 Os sentidos do trabalho, ensaio sobre a afirmação e negação do trabalho. $2^{\mathrm{a}}$ ed. São Paulo: Boitempo, 2009, p. 31-33.

4 ANTUNES, Ricardo. Op. cit., p. 33-38. 
trabalho se afasta das empresas principais, mais tende a se precarizar 5 .

Em síntese, o toyotismo caracteriza-se pelo trabalho em equipe, pela rotação de postos, pelo aprendizado por experiência, pela produção flexível e pelos complexos integrados de produção. Destacam-se dois elementos: "kanban", que se refere à senha que indica a necessidade de reposição de peças ou produtos após a venda e o "just in time", relacionado à manutenção de estoques mínimos, de modo que a produção seja determinada segundo o ritmo da demanda ${ }^{6}$.

A crise dos anos 70 promoveu uma mudança qualitativa na visão das relações de trabalho e do vínculo existente entre regulação normativa e exigências econômicas. Essas mudanças foram influenciadas pelas transformações que desde então se verificaram na economia mundial e no sistema produtivo: surgimento de novos centros econômicos, de novas tecnologias (revolução tecnológica, especialmente a robotização e a informática), a generalização de novos modos de organização e distribuição do trabalho, a globalização da comunicação e dos fluxos econômicos. Os impactos nas relações de trabalho puderam ser sentidos pelo grande número de desempregados, pelo desenvolvimento do trabalho informal e do subemprego, pelo incremento de inúmeras formas precárias de contratação, pelo arrocho salarial. Por outro lado, as alterações nas relações de trabalho foram observadas pela necessidade de novas formas de contratação, pelo uso em grande escala do trabalho autônomo, da terceirização, das cooperativas, pela previsão de novas formas de contrato por prazo determinado, pela jornada a tempo parcial, pelo banco de horas ${ }^{7}$.

Surge, neste contexto, os debates em torno da flexibilização da legislação trabalhista como resposta à crise dos anos 70 nos países centrais ${ }^{8}$ e nos anos 90 no Brasil.

Flexibilidade ou adaptabilidade são expressões emprestadas da teoria da administração e da engenharia que passaram a ser utilizadas no Direito do Trabalho a partir

5 ANTUNES, Ricardo. Op. cit, p. 49-59.

$6 \quad$ SILVA, Walküre Lopes Ribeiro da. Crise de representatividade e participação dos sindicatos em políticas ativas de emprego. Tese apresentada para concurso de Professor Titular de Direito do Trabalho da Faculdade de Direito da Universidade de São Paulo. São Paulo, 2001, p. 31.

BELTRAN, Ari Possidonio. Op. cit., p. 154-157 e 176-177.

8 A exigência de flexibilização das leis e das relações laborais surge, nos anos 80 , entre as organizações empresariais e alguns governos europeus com o objetivo de fomentar e estimular a criação de novas indústrias e de novos empregos, permitir a introdução de novas tecnologias automatizadas e incrementar a competitividade dos mercados internacionais (MARTINEZ, Arturo. Flexibilização de normas e os novos rumos do direito do trabalho. In ZAINAGHI, Domingos Sávio; FREDIANI, Yone (coordenadores). Novos rumos de direito do trabalho na América Latina. São Paulo: Ltr, 2003, p. 132). 
da consciência da globalização econômica. Flexibilidade significa plasticidade ou maleabilidade e adaptabilidade traz consigo a ideia de ajustamento ou amoldamento 9 .

A flexibilização das normas trabalhistas consiste em um processo relacionado à adaptação dos preceitos que regulamentam as relações laborais às grandes alterações que afetam o mundo do trabalho, como as crises econômicas, a globalização e o desenvolvimento tecnológico. Trata-se de uma adaptação do Direito do Trabalho às novas realidades da sociedade, com atenuação dos níveis de proteção laboral ${ }^{10}$.

$\mathrm{Na}$ verdade, deve-se considerar que "flexibilização" não se confunde com "desregulamentação". Nesta, retira-se a proteção do Estado ao trabalhador, permitindo-se que a autonomia privada, individual ou coletiva, regule as condições de trabalho e os direitos e obrigações advindos da relação de emprego. Já na flexibilização, há a intervenção do Estado, ainda que de forma básica, instituindo normas básicas abaixo das quais não se pode conceber a vida do trabalhador com dignidade ${ }^{11}$.

Neste sentido, Sergio Pinto Martins define a flexibilização das condições do trabalho como "o conjunto de regras que tem por objetivo instituir mecanismo tendente a compatibilizar as mudanças de ordem econômica, tecnológica, política ou social existentes nas relações entre o capital e o trabalho". Não corresponde, portanto, à revogação ou exclusão de direitos trabalhistas, mas à modificação de certos direitos mediante negociação coletiva. Trata-se de uma forma de atenuar o princípio da proteção à relação laboral. A flexibilização, por sua vez, diferencia-se da precarização do trabalho, já que, nesta, o trabalho é incerto, indefinido, com uma regulamentação insuficiente ou inexistente, que leva à marginalização do trabalhador. ${ }^{12}$

9 PROSCURCIN, Pedro. O trabalho na reestruturação produtiva - análise jurídica dos impactos no posto de trabalho. São Paulo: Ltr, 2001, p. 98.

10 BELTRAN, Ari Possidonio. Op. cit., p. 158-162. Maria do Rosário Palma Ramalho coloca que o processo de flexibilização do Direito do Trabalho afeta a relação de trabalho típica em duas vertentes: a) diante da diversidade das situações laborais, os sistemas se mostram mais receptivos a formas alternativas de prestação de trabalho subordinado e se voltam à zona cinzenta entre o trabalho subordinado e autônomo, incentivando este último; b) verifica-se um apelo à reestruturação interna da relação de trabalho, notadamente, relacionada ao tempo de trabalho, mobilidade geográfica e funcional de trabalhadores, cessação do contrato de trabalho visando melhor adaptação às novas exigências econômicas e de organização empresarial (Da autonomia dogmática do Direito do Trabalho. Coimbra: Almedina, 2001, p. 590-591).

11 BELTRAN, Ari Possidonio. Op. cit., p. 158-162. O tema da flexibilização, segundo o autor, é polêmico na doutrina, que se divide entre aqueles que a vêem como uma modernização das relações de trabalho ditada pelas conjunturas da atualidade, enquanto outros a consideram como uma desregulamentação do aparato protetor, em razão da onda neoliberal, a promover a precarização do Direito do Trabalho.

12 MARTINS, Sergio Pinto. Flexibilização das condições de trabalho. 4a .ed. São Paulo: Atlas, 2009, p. 915. 
A doutrina analisa a relação entre Direito do Trabalho e flexibilização de duas maneiras: a) polarização: estuda a situação de atrito entre a sua função tutelar e a desproteção que resultaria da flexibilização dos direitos dos trabalhadores e b) integração: verifica a possibilidade de adequada combinação entre os dois objetivos, com o afastamento do paternalismo e sua substituição pela tutela razoável e pela coordenação entre os interesses do capital e do trabalho (implicando a transferência da tutela do Estado e das leis para o sindicatos e os contratos coletivos de trabalho $)^{13}$.

A legislação trabalhista teve seus pilares estabelecidos à luz do trabalho realizado, em todas as suas etapas, nas indústrias ${ }^{14}$, mediante o modelo de produção em massa, baseado em uma estreita especialização das tarefas e das competências e em uma organização hierárquica e coletiva do trabalho ${ }^{15}$. Esta relação de trabalho industrial se caracterizava por um vínculo por tempo indeterminado, a tempo inteiro e com exclusividade, em que o trabalhador se integrava intensamente na organização da empresa, submetido a modelos rígidos de hierarquia e de determinação da função a ser exercida. O trabalhador subordinado típico era tendencialmente homem, provedor financeiro da família, economicamente dependente do salário e sem grandes habilitações ${ }^{16}$.

O surgimento de novas profissões e a expansão do setor terciário, promovidos pelo avanço tecnológico, trouxeram a necessidade de atualização da legislação trabalhista às novas realidades. Esta necessidade de adaptação é inexorável, pois a economia e a sociedade são as circunstâncias que influenciam diretamente o Direito do Trabalho e estão submetidas a um processo de mudanças permanentes. Em outras palavras, o conteúdo institucional deste ramo do Direito se submete, naturalmente, às contingências históricas e políticas. Assim, se o plano que serviu de base ao Direito do Trabalho muda

13 SILVA, Otavio Pinto e. A função do Direito do Trabalho no mundo atual. In CORREIA, Marcus Orione Gonçalves (organizador). Curso de Direito do Trabalho - Teoria Geral do Direito do Trabalho. Volume I. Ltr, 2007-2008, p. 141.

14 A CLT reproduz a fábrica vertical e concentrada, o trabalho parcelado, homogêneo e em série característico do fordismo. Porém, a fábrica moderna se desconcentrou, organizando-se em rede e articulando-se com outras e recorre a empregados informais e a trabalhadores autônomos, não apenas os falsos, mas também os verdadeiros autônomos. Verifica-se a proliferação de formas não empregatícias de relações de trabalho (MERÇON, Paulo Gustavo de Amarante. Direito do Trabalho Novo. In Revista Ltr, vol. 75, $\mathrm{n}^{\mathrm{o}}$ 01, janeiro de 2011, p. 87).

15 PALOMEQUE LÓPEZ, Manuel Carlos. Trabajo subordinado y trabajo autónomo en el ordenamiento laboral español. In Revista Gaceta Laboral, vol. 10, n. 01, ene/abr 2004, p. 64-65.

16 RAMALHO, Maria do Rosario Palma. Modernizar o Direito do Trabalho para o século XXI. Notas breves sobre o Livro Verde da Comissão Europeia, de 22 de novembro de 2006, e sobre os desafios da flexisegurança. In NAHAS, Thereza Christina (coordenadora). Princípios de direito e processo do trabalho: questões atuais. Rio de Janeiro, Campus: Elsevier, 2009, p. 34-35. 
fundamentalmente, não pode mais esse direito ter influência sobre o mundo diferente. Neste contexto, a adaptação dos modelos clássicos por outros modelos de ocupação (exemplificativamente, trabalho de duração limitada, a tempo parcial) é inevitável sob o aspecto da criação de novos empregos. As relações entre economia e o direito do trabalho são múltiplas e a influência das regras de direito do direito do trabalho sobre o mercado é considerável $^{17}$.

Em uma concepção mais moderna, o direito do trabalho mostra-se como um instrumento de síntese dos interesses comuns ao capital e ao trabalho. Assim, não se destina apenas a compensar a inferioridade econômica do trabalhador, mas também se abre para a organização da produção ${ }^{18}$. A adequação tão almejada da legislação trabalhista aos novos rumos da modernidade deve ser empreendida sem se descurar do princípio da justiça social, já que o trabalho não é artigo de comércio, eis que representa um direito e um dever social. Atitude diversa implicará em um retrocesso das conquistas obtidas pelas lutas socais e um perigo à paz ${ }^{19}$.

Referida adaptação, portanto, não significa uma fuga ao Direito do Trabalho e a seus custos, mas representa estratégia de inovação em setores de alto nível de qualificação ${ }^{20}$.

Deve-se evitar que as propostas passem de uma flexibilidade de adaptação para uma flexibilidade de desregulamentação. Isto significa dizer que é preciso reconhecer uma certa limitação na aspiração de flexibilidade, separando o que se justifica e

17 BARROS, Cassio Mesquita de. O futuro do direito do trabalho. In ZAINAGHI, Domingos Sávio, FREDIANI, Yone (coords). Novos rumos do direito do trabalho na América Latina. São Paulo: Ltr, 2003, p. 11-18. PALOMEQUE LÓPEZ, Manuel Carlos. Op. cit., p. 67.

18 ROBORTELlA, Luis Carlos Amorim, PERES, Antonio Galvão. Novas tendências do mercado de trabalho: Crise do trabalho subordinado, crescimento do trabalho autônomo e de pessoas jurídicas. In ANAN JR., Pedro e PEIXOTO, Marcelo Magalhães (coordenadores). Prestação de serviços intelectuais por pessoas jurídicas: aspectos legais, econômicos e tributários. São Paulo: MP Ed, 2008, p. 124.

19 MARTINEZ, Arturo. Op. cit., p. 134-136. Neste mesmo sentido, Ives Gandra da Silva Martins Filho entende que o grande desafio do moderno direito laboral é a de encontrar o justo equilíbrio na questão da flexibilização de suas normas de modo a não inviabilizar a atividade produtiva em uma economia globalizada (Exigências de um novo direito do trabalho. In MARTINS, Ives Gandra e CAMPOS, Diogo Leite de (coordenadores). O direito contemporâneo em Portugal e no Brasil. São Paulo: Saraiva, 2004, p. 341-342).

20 MANNRICH, Nelson. Relações de trabalho autônomo e subordinado: proposta para instituir critérios para sua distinção. In BRAMANTE, Ivani Contini, CALVO, Adriana (organizadores). Aspectos polêmicos e atuais do direito do trabalho. São Paulo: Ltr, 2007, p. 152-154. Referido autor pondera que a falta de atualização da legislação trabalhista brasileira diante das transformações econômicas e sociais faz com que algumas empresas passem a promover sua reforma de maneira unilateral, ensejando um cenário de promiscuidade nas relações trabalhistas. Mas nem sempre tais expedientes são utilizados com um intuito fraudulento. 
o que não se justifica, pois a completa supressão de rigores e imposições legais promove a destruição do Direito do Trabalho. Os princípios deste ramo do Direito possuem uma capacidade de adaptação a diversas realidades que lhes retira a rigidez e os torna capazes de conduzir e acompanhar as tentativas de flexibilização. Possuem, em síntese, suficiente maleabilidade para serem aplicados em diversas situações. O Direito do Trabalho tem um estreito contato com a vida social, o que o torna particularmente sensível às exigências do mundo dos fatos. Deve manter-se fiel aos seus princípios aplicando-os adequadamente às realidades que se colocam ${ }^{21}$.

Portanto, flexibilizar não significa desregular, mas regular novamente, diferente do que se acha regulado ${ }^{22}$. Como observa Pedro Proscurcin, não é de interesse dos sistemas econômico, político e jurídico a fuga desenfreada da regulação ou a tentativa de remercantilização das relações laborais imposta pelo empresariado sob o argumento de que o Direito do Trabalho impede o desenvolvimento da empresa, aumenta os custos e dificulta a competitividade. A desregulamentação significa anomia e uma causa perene de instabilidade e conflito, que pode comprometer a continuidade do próprio sistema ${ }^{23}$.

O grande desafio que se coloca ao jurista, atualmente, é a redefinição da regulamentação das relações de trabalho, de modo que o Direito do Trabalho possa manter a sua histórica vocação de proteção dos hipossuficientes, mas sem que isto signifique um obstáculo ao desenvolvimento da economia. A revisão do modelo brasileiro de relações de trabalho deve ter como objetivos principais o combate à economia informal e à exclusão social, dentro de uma perspectiva de valorização do trabalho como uma maneira de assegurar aos cidadãos o acesso aos direitos humanos fundamentais ${ }^{24}$.

\subsection{Da flexissegurança.}

$\mathrm{Na}$ Europa, as medidas de flexibilização foram adotadas de uma forma mais precoce e intensa por alguns países e de maneira mais tímida e tardia por outros. As

${ }^{21}$ PLÁ RODRIGUES, Américo. Princípios de direito do trabalho. Tradução de Wagner D. Giglio. $3^{\mathrm{a}}$ ed., atual. São Paulo: Ltr, 2000, p. 76-82.

22 SILVA, Otavio Pinto e. Op. cit., p. 141-142.

23 Do contrato de trabalho ao contrato de atividade: nova forma de regulação das atividades do mercado de trabalho. São Paulo: Ltr, 2003, p. 335-336.

24 SILVA, Otavio Pinto e. Op. cit., p. 141-142. 
estratégias utilizadas para sua implementação oscilaram desde mecanismos de desregulamentação pura - com a devolução de algumas matérias antes reguladas pela lei às partes em sede do próprio contrato de trabalho - até mecanismos de re - regulamentação regimes legais que podem ser afastados por convenções coletivas de trabalho, mas não em sede do contrato de trabalho ${ }^{25}$.

Como consequências, aponta-se que a flexibilização foi efetivada à custa da proteção do trabalhador ante a diminuição da segurança tradicionalmente garantida pelos regimes laborais. Além disso, criou uma segmentação do mercado de trabalho entre os trabalhadores típicos, também denominados insiders, que correspondem àqueles que ainda se beneficiam da tutela decorrente do trabalho subordinado por tempo indeterminado e os trabalhadores atípicos, denominados outsiders, que possuem um outro modelo de contrato de trabalho ou se encontram em uma zona cinzenta entre o trabalho subordinado e a prestação de serviços ${ }^{26}$.

A observação destes efeitos desfavoráveis da flexibilização consistente na proliferação de categorias de trabalhadores com níveis diferenciados de tutela desencadeou a abordagem do tema da flexissegurança, que sugere a combinação da flexibilidade com a segurança ${ }^{27}$.

Este novo modelo foi denominado na França, desde 1990, como flexsécurité e, nos países de língua inglesa, como flexsecurity ${ }^{28}$. Seu objetivo é alcançar uma nova abordagem da flexibilidade através dos seguintes preceitos: capacitação do trabalhador durante sua vida; políticas que incentivem desempregados a buscar nova recolocação no mercado e regras mais flexíveis no âmbito da segurança social para atender às necessidades daqueles que mudam de emprego ou o perdem provisoriamente ${ }^{29}$.

O tema foi o objeto de análise do "Livro Verde - Modernizar o direito do

25 RAMALHO, Maria do Rosario Palma. Modernizar o Direito do Trabalho para o século XXI. Notas breves sobre o Livro Verde da Comissão Europeia, de 22 de novembro de 2006, e sobre os desafios da flexisegurança. In NAHAS, Thereza Christina (coordenadora). Princípios de direito e processo do trabalho: questões atuais. Rio de Janeiro, Campus: Elsevier, 2009, p.36

26 Ibidem, p. 37.

27 Ibidem, p. 37-38.

28 PEDREIRA, Pinho. Um novo modelo social: a flexissegurança. In Revista Ltr, vol 69, $\mathrm{n}^{\circ} 06$, junho de 2005, p. 645.

29 LEMOS, Luciane Souza Soares de. Flexissegurança - aspectos gerais. In Revista trabalhista - Direito e processo, São Paulo, a . 9, n. 33, janeiro/março 2010, p. 146. A autora pondera tratar-se de uma terminologia nova que se apresenta escrita, também, das seguintes maneiras: flexissegurança, flexisegurança, flexisegurança, flexigurança. 
trabalho para enfrentar os desafios do século XXI", publicado em novembro de 2006 pela Comissão Europeia ${ }^{30}$, que visou fomentar um debate público na União Europeia acerca da evolução do direito do trabalho à luz dos objetivos da Comunidade relacionados ao pleno emprego, produtividade laboral e coesão social. Destacam-se a mobilização de recursos para a promoção de uma mão de obra competente, formada e adaptável e um mercado de trabalho que dê respostas aos impactos advindos da globalização e de envelhecimento da população da Europa $^{31}$.

De acordo com referido documento, os mercados de trabalho europeus devem compatibilizar uma maior flexibilidade com a necessidade de proporcionar mais segurança a todos. Diante do surgimento de novas formas contratuais, que divergem do modelo clássico, verificou-se a necessidade de adaptação da legislação do trabalho para promover a flexibilidade com a segurança do emprego a fim de reduzir a segmentação do mercado de trabalho antes já descrita pela existência de trabalhadores com empregos permanentes ("insiders") e pela existência de desempregados ou trabalhadores em situação de emprego precárias ou informais (“outsiders") 32 .

A flexissegurança, em sua dimensão política, envolve aprendizagem ao longo da vida, políticas ativas de mercado de trabalho voltadas a incentivar os inativos a procurar novas oportunidades de emprego e regras mais maleáveis no campo da segurança social para atender às necessidades daqueles que mudam de emprego ou abandonam temporariamente o mercado de trabalho. O Livro pretende debater como o Direito do Trabalho pode promover a flexissegurança visando a construção de um mercado mais justo, inclusivo e reativo. Para tanto, são analisados os seguintes aspectos: a) identificação dos principais desafios decorrentes do desequilíbrio entre os quadros jurídicos e contratuais vigentes e as realidades do mundo do trabalho; b) promover a participação dos governos, parceiros sociais e outras partes interessadas no debate; c) discutir a possibilidade de existência de diferentes tipos de relações contratuais, bem como de direitos na esfera laboral aplicáveis a todos os trabalhadores; d) contribuir para o projeto "Legislar melhor",

30 RAMALHO, Maria do Rosario Palma. Op. cit., p. 31-32

31 Comissão das Comunidades Europeias, Livro verde - modernizar o direito do trabalho para enfrentar os desafios do século XXI, Bruxelas, 22.11.2006, p. 03. Disponível no site http://eurlex.europa.eu/LexUriServ/site/pt/com/2006/com2006 0708pt01.pdf, acesso 05.03.2013.

32 Comissão das Comunidades Europeias, Livro verde - modernizar o direito do trabalho para enfrentar os desafios do século XXI, Bruxelas, 22.11.2006, p. 03-04. Disponível no site http://eurlex.europa.eu/LexUriServ/site/pt/com/2006/com2006 0708pt01.pdf, acesso 05.03.2013. 
incentivando a modernização do direito do trabalho considerando os benefícios e os custos globais em causa ${ }^{33}$.

Portanto, verifica-se que a flexibilidade dos mercados de trabalho deve ser concebida conjuntamente com a ideia de segurança para o trabalhador como contraponto à maior mobilidade que lhe é imposta em consequência dos modelos de emprego que impõem maior flexibilidade. $O$ debate da flexibilidade passa a abordar questões relacionadas à qualidade das seguranças sociais que são ou devem ser atribuídas ao trabalhador, como apoios que permitam o sustento durante o período de desemprego (seguro-desemprego) e melhorem sua potencial empregabilidade (capacitação) facilitando o regresso ao emprego. O debate deve ser travado entre governos, sindicatos de trabalhadores e o patronato dentro de um contexto de respeito às leis laborais e de fomento à negociação coletiva. $\mathrm{O}$ objetivo é não só garantir maior competitividade aos empreendimentos econômicos (flexibilidade), mas também garantir uma forma de inclusão social dos trabalhadores (segurança) ${ }^{34}$.

Abandona-se a ideia de segurança do emprego e adota-se a segurança da empregabilidade, incentivando-se a aprendizagem e a formação durante toda a vida. A proteção do emprego pode não se mostrar suficiente, pois para planejar sua vida e sua carreira os trabalhadores necessitam de um outro tipo de segurança que lhes permita permanecer no mercado de trabalho, que lhes permita fazer a transição de um emprego a outro $^{35}$. Nas palavras de Maria do Rosário Palma Ramalho, "flexisegurança não é a segurança no emprego, mas, essencialmente, a segurança no desemprego dos trabalhadores" ${ }^{36}$.

A autora aponta duas conclusões que podem ser extraídas do debate travado no âmbito europeu: a primeira indica que a flexissegurança não visa promover qualquer retrocesso no processo de flexibilização dos sistemas laborais, pelo contrário,

33 Comissão das Comunidades Europeias, Livro verde - modernizar o direito do trabalho para enfrentar os desafios do século XXI, Bruxelas, 22.11.2006, p. 04-05. Disponível no site http://eurlex.europa.eu/LexUriServ/site/pt/com/2006/com2006 0708pt01.pdf, acesso 05.03.2013.

34 SCHWARZ, Rodrigo Garcia. A política europeia de emprego e a ideia de "flexissegurança": um novo paradigma para a "modernização" do direito do trabalho. In Revista do Tribunal Regional do Trabalho da $3^{a}$ Região, Belo Horizonte, v. 48, n. 78, jul/dez. 2008, p. 66-67.

35 ROMITA, Arion Sayão. Flexigurança: a reforma do mercado de trabalho. São Paulo: Ltr, 2008, p. 80-81.

36 Modernizar o Direito do Trabalho para o século XXI. Notas breves sobre o Livro Verde da Comissão Europeia, de 22 de novembro de 2006, e sobre os desafios da flexisegurança. In NAHAS, Thereza Christina (coordenadora). Princípios de direito e processo do trabalho: questões atuais. Rio de Janeiro, Campus: Elsevier, 2009, p. 40. 
verifica, inclusive, a possibilidade de aumentar o grau de flexibilidade em alguns regimes. A flexibilização do Direito do Trabalho é vista como algo consolidado, estrutural (não conjuntural) e irreversível. A segunda conclusão é a de que a flexissegurança é vista como um conjunto de estratégias destinadas a contornar alguns efeitos maléficos promovidos pela flexibilização. Pretende-se, com isto, aumentar a segurança dos trabalhadores sem comprometer, globalmente, a flexibilização dos sistemas laborais ${ }^{37}$.

Foi na Dinamarca que a flexissegurança alcançou maior importância e passou a servir de exemplo aos demais países europeus. O modelo assenta-se no chamado "triângulo de ouro" composto por disposições contratuais flexíveis, amplos sistemas de indenização e políticas ativas. O mercado de trabalho deste país, diante da ausência de regras rigorosas sobre demissões e diante da existência de um elevado número de pequenas e médias empresas, é marcado por um alto nível de mobilidade dos trabalhadores. Há, ainda, um sistema público de educação dirigido de acordo com as necessidades de qualificação das empresas e uma tradicional forma de contratação coletiva centralizada, marcada pela colaboração entre as entidades de classe laborais e patronais com o governo. Os trabalhadores desempregados são compelidos a procurar uma nova ocupação e a prosseguir nos programas gerais de ativação integral, que os qualifica e ajuda a motivá-los 38.

Os resultados da implantação de um modelo de flexissegurança dependem das características próprias de cada país, como cultura e mercados de trabalho. Assim, nos países nórdicos como Dinamarca, Áustria e Suécia, os frutos positivos decorreram das peculiaridades destes países que favoreceram este novo sistema. No entanto, na Alemanha, por exemplo, a flexissegurança representa uma flexibilização de direitos apenas em relação aos trabalhadores, com uma redução do nível da proteção social e a ausência de preocupação com a qualificação profissiona $\mathrm{l}^{39}$. $\mathrm{O}$ modelo alemão reduz a proteção social em caso de desemprego, compelindo os desempregados a gastar suas poupanças e os seguros que previram para a velhice ${ }^{40}$.

Analisando a situação brasileira, Tabajara Medeiros de Rezende Filho

37 Op. cit., p. 38-39.

38 LEMOS, Luciane Souza Soares de. Op. Cit., p. 150-151.

39 SOUSA, Taysa Queiroz Mota de. Flexissegurança e sua influência no Brasil. In Revista da ESMAT 13, ano $4, n^{\circ} 4$, outubro de 2011, p. 251-257.

40 LEMOS, Luciane Souza Soares de. Op. cit., p. 155. 
coloca que não há um modelo de flexicurity no país, embora o principal elemento de flexibilização consistente na facilidade da dispensa do empregado já exista. É possível criar medidas de fomento à contratação, através do reconhecimento de tipologias contratuais flexíveis. Aponta que o Brasil é um dos poucos países da América Latina que prevê a concessão de seguro-desemprego. Para o autor, o desenvolvimento atual do país permite a introdução de medidas de flexissegurança, que podem contribuir para a mitigação dos efeitos da crise econômica ${ }^{41}$.

Considerando-se a existência de ampla dose de flexibilidade em grande parte das legislações trabalhistas, inclusive a brasileira, impõe-se a melhoria das políticas de mercado de trabalho para assegurar flexibilidade do emprego com a segurança individual ${ }^{42}$. Deve-se impedir que a flexissegurança seja utilizada apenas como forma de flexibilizar direitos trabalhistas com o único intuito de favorecer apenas à classe econômica da relação, sem se preocupar com a proteção ao trabalhador ${ }^{43}$.

41 Do protecionismo do empregado à proteção do trabalhador: desafios da flexicurity. Tese de Doutorado em Direito do Trabalho apresentada à Faculdade de Direito da Universidade de São Paulo. Professor orientador: Nelson Mannrich. São Paulo, 2013, p. 71 e 87.

42 ROMITA, Arion Sayão. Op. cit., p. 84

43 SOUSA, Taysa Queiroz Mota de. Op. cit., p. 253 


\section{Capítulo 2 - RELAÇÕES DE TRABALHO}

\subsection{Considerações iniciais.}

O trabalho humano pode ser prestado de diversas maneiras, cabendo ao Direito regulá-las, diferenciá-las e classificá-las, atribuindo efeitos jurídicos a cada relação contratual $^{44}$.

O conceito de relação de trabalho é amplo, abrange todo contrato de atividade e o elemento de sua conceituação é a pessoa do trabalhador, qualquer que seja a modalidade de serviço prestado. Pode, assim, ser definido como o vínculo jurídico estipulado, expressa ou tacitamente, entre um trabalhador (pessoa física) e uma pessoa física ou jurídica, que o remunera pelos serviços prestados ${ }^{45}$. Em termos teóricos, fala-se que há um contrato de prestação de serviços em sentido amplo, que engloba a prestação de serviços subordinada e a prestação de serviço autônoma, que corresponde ao contrato de prestação de serviço propriamente dita ${ }^{46}$.

A construção institucional do Direito do Trabalho, bem como o seu âmbito de aplicação, repousa, tradicionalmente, sobre uma diferenciação técnica entre trabalho subordinado e trabalho autônomo ${ }^{47}$.

Assim, são considerados trabalhadores todos aqueles que prestam algum tipo de serviço ou atividade humana e são considerados empregados apenas os trabalhadores que preenchem alguns requisitos, dentre os quais o mais importante é o da subordinação. O Direito do Trabalho concentra seu estudo e sua proteção a um grupo não majoritário de trabalhadores que são os empregados. Trata-se da relação de trabalho típica, usualmente identificada com a relação de trabalho empresarial e industrial, duradoura ou por tempo indeterminado, com uma integração plena do trabalhador na empresa e a qual se confere certo nível de tutela ao trabalhador ${ }^{48}$.

44 SILVA, Otavio Pinto e. Subordinação, autonomia e parassubordinação nas relações de trabalho. São Paulo: LTr, 2004, p. 13.

45 SUSSEKIND, Arnaldo. Da relação de trabalho. In Revista Ltr, vol. 74, n. 03, março de 2010, p. 263.

46 MARTINEZ, Pedro Romano. Direito do trabalho. 4ª ed. Coimbra: Almedina, 2007, p. 300.

47 PALOMEQUE LÓPEZ, Manuel Carlos. Trabajo subordinado y trabajo autónomo en el ordinamiento laboral español. In Revista Gaceta Laboral, Maracaibo, Venezuela, vol 10., nº 01, ene./abr. 2004, p. 62.

48 SILVA, Homero Batista Mateus da. Curso de direito do trabalho aplicado. Volume 1: Parte geral. Rio de 
Neste sentido, dedica pouca atenção às demais formas de atividade humana que correspondem a grande segmento da sociedade como os autônomos, representantes comerciais, eventuais, voluntários e estagiários ${ }^{49}$. Assim, a maior parte das relações de trabalho lato sensu ainda é regulada pelo direito comum e por legislações especiais $^{50}$ (como exemplo, temos o disposto nos artigos 593 a 609, do Código Civil que dispõe sobre a prestação de serviço).

\section{A contraposição entre trabalho subordinado e trabalho autônomo} sempre esteve presente nos debates da doutrina e da jurisprudência, mas entre estes dois pólos, vem ganhando destaque uma terceira entidade, a parassubordinação ${ }^{51}$, cujo surgimento guarda relação com as transformações do mundo do trabalho já mencionadas, visando atender certas particularidades.

Fala-se, portanto, em uma erosão da relação de trabalho típica, em uma crise do direito laboral ao nível da relação de trabalho, processo este que se desenvolve tanto a partir de dentro como a partir de fora do vínculo laboral. Assim, do ponto de vista externo, tem-se o aumento das relações laborais atípicas, o recrudescimento do trabalho autônomo e das situações intermediárias de parassubordinação, que parecem corresponder melhor à exigências específicas de certas atividades econômicas, ou parecem se adaptar mais facilmente aos objetivos de contenção de custos, de miniaturização e de especialização das empresas. Do ponto de vista interno, a erosão da relação de trabalho típica se mostra pelas dúvidas colocadas em relação a alguns dos aspectos garantísticos de seu regime, considerado demasiadamente rígido, e que se revelam incompatíveis com as novas exigências de competitividade ${ }^{52}$.

Janeiro: Elsevier, 2009, p. 11-12; RAMALHO, Maria do Rosário Palma. Ainda a crise do direito laboral: a erosão da relação de trabalho típica e o futuro do direito do trabalho. IN Estudos de Direito do Trabalho. Volume I. Coimbra: Almedina, 2003, p. 109-110.

49 SILVA, Homero Batista Mateus da. Op. cit., p. 11-12.

50 MERÇON, Paulo Gustavo de Amarante. Direito do trabalho novo. In Revista Ltr, vol. 75, $\mathrm{n}^{\circ}$ 01, janeiro de 2011, p. 86.

51 LEVI, Alberto. Distinzioni tra le relazioni di impiego e i contratti de prestazioni di servizi. Contratto atipici nel diritto italiano. In Revista de Direito do Trabalho, ano 33, n. 128, out-dez. 2007, p. 257-258.

52 RAMALHO, Maria do Rosário Palma. Ainda a crise do direito laboral: a erosão da relação de trabalho típica e o futuro do direito do trabalho. IN Estudos de Direito do Trabalho. Volume I. Coimbra: Almedina, 2003, p. 114-116. A autora pondera que, em relação às relações laborais atípicas, algumas já existiam e eram consideradas marginais, ao passo que outras são novas, decorrentes dos novos modelos de organização produtiva. Descreve que a atipicidade pode decorrer da precariedade do vínculo (contratos de trabalho a termo); do fato de o trabalhador não se integrar na estrutura de pessoal da empresa para a qual trabalha (trabalhadores temporários); do fato de o trabalhador não dedicar todo o seu dia de trabalho à empresa (trabalho a tempo parcial); ou pelo fato de o trabalhador desenvolver sua prestação laboral fora das instalações da empresa (trabalho em domicílio, teletrabalho). 
Maria do Rosário Palma Ramalho coloca que a opção por formas alternativas à relação laboral típica permite tanto uma multiplicação de formas de contratação laboral até então consideradas marginais (como o trabalho a termo, o trabalho a tempo parcial) como também permite a chamada "fuga ao direito do trabalho", seja de maneira lícita, com o desenvolvimento do trabalho autônomo para além das profissões liberais (tendência que já foi denominada como o "ressurgimento da prestação de serviços"), seja de maneira ilícita, mediante a proliferação dos falsos independentes e do trabalho clandestino (processo chamado pelos juristas como "erosão da relação laboral típica e pelos economistas como decomposição da relação salarial") $)^{53}$.

À luz destas considerações, neste Capítulo, serão analisados os trabalhos subordinado, autônomo e parassubordinado. Nos Capítulos seguintes, a abordagem se voltará à constituição de pessoa jurídica pelo trabalhador para a prestação de serviços, que poderá ser lícita ou poderá ser uma maneira de burlar a legislação trabalhista.

\subsection{Trabalho Subordinado.}

A questão da individualização da natureza da relação de trabalho é preliminar a qualquer outra e a subordinação constitui o elemento chave para a incidência das normas trabalhistas. A ela é confiada a função de distinguir a relação típica objeto de tutela deste ramo do Direito. A história do Direito do Trabalho se identifica largamente com a história da subordinação e, nesta trajetória, não cessam os esforços, especialmente doutrinários, de aperfeiçoamento desta noção, na tentativa de fazê-la adquirir uma idoneidade satisfatória de qualificação da relação objeto da disciplina típica ${ }^{54}$.

$\mathrm{Na}$ verdade, críticas à subordinação como critério fundamental de definição da relação de emprego e, por consequência, de aplicação do Direito do Trabalho sempre existiram. Todavia, as críticas atuais se inserem em um contexto muito mais amplo de crítica ao Direito do Trabalho como um todo. Para além de questionamentos pontuais a uma ferramenta técnica, a crise atual da subordinação forma parte essencial da crise do

53 Da autonomia dogmática do Direito do Trabalho. Coimbra: Almedina, 2001, p. 555-556.

${ }^{54}$ CARINCI, Franco, TAMAJO, Raffaele de Luca, TOSI, Paolo, TREU, Tiziano. Diritto del lavoro, il rapporto di lavoro subordinato. Sesta edizioni. UTET giuridica, p. 17-19. 
Direito do Trabalho ${ }^{55}$.

A nossa realidade social promoveu a aproximação de fato entre empregados e trabalhadores ditos autônomos, sendo esta diferença cada vez mais tênue em determinados segmentos da economia, principalmente naqueles em que se utilizam serviços em rede de pequenas e microempresas, profissionais especializados, terceirização de serviços, trabalho a domicílio (teletrabalho, confecção, fabricação de componentes para a grande contratante, consultoria, etc), pequenas empreitadas e subempreitadas, firmas de distribuição e franchising ${ }^{56}$.

Em 2006, a OIT adotou a Recomendação 198, denominada Recomendação do Relacionamento Empregatício, tendo em vista as dificuldades de definição da existência ou não de uma relação de emprego quando não resultam claros os direitos e obrigações das partes interessadas, quando se busca encobrir uma relação de emprego, quando há insuficiências ou limitações da legislação nacional, em sua interpretação ou em sua aplicação. Assim, os Membros deveriam formular e aplicar uma política nacional destinada a examinar, esclarecer e adaptar, em certa periodicidade, o âmbito de aplicação da legislação pertinente visando garantir uma proteção efetiva aos trabalhadores que exercem sua atividade no âmbito de uma relação de emprego ${ }^{57}$.

Para os fins desta política nacional, a existência de uma relação de emprego deve ser determinada de acordo com a forma de execução do trabalho e de acordo com a remuneração do empregado. Em relação ao primeiro critério, qual seja, a forma de execução do trabalho, a Recomendação sugere a consideração de alguns indícios como: se o trabalho é realizado conforme as instruções e sob o controle de outra pessoa; se há a integração do trabalhador na organização da empresa; se a atividade é efetuada única ou principalmente em benefício de outrem; se é realizada pessoalmente, dentro de um horário determinado ou em lugar indicado ou aceito por quem solicita o trabalho; se o trabalho é de certa duração ou possui certa continuidade, ou requer a disponibilidade do empregado, que implica no fornecimento de ferramentas, materiais e máquinas por parte da pessoa que

55 URIARTE, Oscar Ermida, ALVAREZ, Oscar Hernández. Apuntes sobre los cuestionamientos al concepto de subordinación. In Revista de Direito do Trabalho, n. 103, ano 27, julho-setembro de 2001, Editora Revista dos Tribunais, p. 202-203.

56 MENEZES, Cláudio Armando C de. Os novos contornos das relações de trabalho e de emprego - Direito do Trabalho e a nova competência trabalhista estabelecido pela Emenda 45/04. In Revista Ltr, vol.69, $\mathrm{n}^{\circ}$ 05, maio de 2005, p. 559.

57 Recomendação 198, da OIT, sobre a relação de trabalho, de 15 de junho de 2006. Disponível em http://www.ilo.org/ilolex/cgi-lex/convds.pl?R198\#Link, acesso 19.02.2012. 
requer o trabalho ${ }^{58}$.

Em relação ao segundo elemento, a forma de remuneração do trabalho, deve-se perquirir se é paga uma remuneração periódica ao trabalhador, se esta remuneração constitui a única ou principal fonte de renda do trabalhador; se há o pagamento em espécie como alimentação, moradia, transporte e outros; se são reconhecidos direitos como descanso semanal e férias anuais; se o contratante paga as viagens necessárias para a execução do trabalho e o fato de não existir riscos financeiros ao trabalhador ${ }^{59}$.

A jurisprudência italiana, ao analisar o trabalho subordinado, menciona o disposto no artigo 2094, do Código Civil italiano, de $1942^{60}$, entendendo que a subordinação comporta a inserção de modo continuativo e sistemático na organização da empresa para o alcance de seus fins produtivos, com a sujeição do trabalhador ao poder organizativo, diretivo e disciplinar do empregador. Portanto, não basta somente a inserção da atividade laborativa na organização da empresa, já que uma estável ligação entre uma e outra pode ocorrer no caso de colaboradores autônomos. Esta inserção deve implicar na consequente sujeição às diretrizes do empregador acerca das formas de execução do trabalho, ou seu desenvolvimento intrínseco, ou seja, a submissão ao poder hierárquico e disciplinar do empegador ${ }^{61}$.

Embora a definição do art. 2094 do Código Civil italiano seja clara,

58 Recomendação 198, da OIT, sobre a relação de trabalho, de 15 de junho de 2006. Disponível em http://www.ilo.org/ilolex/cgi-lex/convds.pl?R198\#Link , acesso 19.02.2012. MANNRICH, Nelson, Relações de trabalho autônomo e subordinado: proposta para instituir critérios para sua distinção. In BRAMANTE, Ivani Contini, CALVO, Adriana (organizadores). Aspectos polemicos e atuais do direito do trabalho. São Paulo: Ltr., 2007, p. 163-164.

59 Recomendação 198, da OIT, sobre a relação de trabalho, de 15 de junho de 2006. Disponível em http://www.ilo.org/ilolex/cgi-lex/convds.pl?R198\#Link , acesso 19.02.2012. MANNRICH, Nelson, Relações de trabalho autônomo e subordinado: proposta para instituir critérios para sua distinção. In BRAMANTE, Ivani Contini, CALVO, Adriana (organizadores). Aspectos polêmicos e atuais do direito do trabalho. São Paulo: Ltr., 2007, p. 163-164.

60 Art. 2094: È prestatore di lavoro subordinato chi si obbliga mediante retribuzione a collaborare nell ímpresa, prestando il próprio lavoro intellettuale o manuale alle dipendenze e sotto la direzione dell'impreditore. (disponível em http://www.diritto.it/static/codici? articolo $\mathrm{id}=36204 \&$ codice id=1\&titolo $\mathrm{id}=40$, acesso 10.02.2012).

61 GAlañTINO, Luisa. Diritto del lavoro. $14^{\mathrm{a}}$ ed. Torino: G. Giappichelli editore, 2006, p. 05. No mesmo sentido, Oscar Ermida Uriarte e Oscar Hernández Alvarez colocam que a inserção na organização empresária, embora seja um elemento próprio da relação de emprego, não é exclusiva desta já que o empresário incorpora no desenvolvimento da atividade empresarial não somente o trabalho de seus próprios empregados, mas também a atividade, contínua mas autônoma de colaboradores que, embora não sejam empregados, estão incorporados ao cumprimento desta atividade econômica organizada que é a empresa de tal maneira que esta não pode cumprir seus objetivos sem estas pessoas (Apuntes sobre los cuestionamientos al concepto de subordinación. In Revista de Direito do Trabalho, n. 103, ano 27, julhosetembro de 2001, Editora Revista dos Tribunais, p. 211). 
individualizando na colaboração e na sujeição do trabalhador aos poderes do empregador os elementos típicos do trabalho subordinado, nem sempre é possível, com facilidade, identificar tais características, seja porque há relações cujos elementos de subordinação se apresentam atenuados (como nos trabalhos atípicos) ou porque se apresentam relações cuja forma de desenvolvimento é muito próxima àquela do trabalho autônomo. Por esta razão, a jurisprudência italiana vem especificando os indícios de uma subordinação. Ou seja, construiu um modelo de trabalho subordinado considerando a maneira como é mais intensamente difundido na realidade, evidenciando os elementos que o caracterizam inequivocamente e os distinguem de outras formas de trabalho ${ }^{62}$.

Alguns critérios derivam diretamente da definição de trabalho subordinado previsto no art. 2094, do Código Civil italiano e, portanto, são considerados essenciais ou principais. São eles: heterodeterminação, entendida como a sujeição pessoal do trabalhador ao empregador e aos seus poderes; colaboração na empresa; continuidade da prestação e inserção na organização do trabalho. Outros indícios, entretanto, intervêm apenas em um segundo momento, caso não seja possível identificar a natureza da relação apenas pelos critérios principais. São os chamados critérios subsidiários ou secundários, que, na realidade, representam, de uma forma superficial, difusa, características tradicionais da subordinação, mas que só são determinantes se acompanhados de outros elementos. São eles: vínculo de horário, garantia e modalidade de retribuição, objeto da prestação, ausência de risco para o trabalhador, dependência do trabalhador a um só empregador, a ausência de organização dirigida pelo trabalhador. Cabe notar que, nos últimos anos, vem ganhando importância a vontade das partes ${ }^{63}$.

Portanto, os elementos secundários devem ser importantes, preciosos e concordes para que possam apontar a existência de um trabalho subordinado nos casos limítrofes ou duvidosos em que a sujeição do trabalhador não seja facilmente verificável ${ }^{64}$.

Em relação a alguns critérios secundários, mostram-se necessárias algumas observações. A dependência do trabalhador a um só empregador não é um critério muito utilizado pela jurisprudência e somente pode ser tido como indicador do trabalho

62 GARATTONI, Marina. Subordinazione, parassubordinazione e colaborazione coordinata e continuativa. Roma: Ediesse, 2003, p. 17.

63 Ibidem, p. 18-20 e 27.

64 GASPARI, Alessandra. La qualificazione di un rapporto di lavoro controverso - le risposte passate e recenti, della dialettica autonomia/subordinazione alla sua metamorfosi in corso. In Lavoro e Previdenza oggi, ano 30, n. 03, março 2003, Milano, p. 414-416. 
dependente quando acompanhado da inexistência de uma organização dirigida pelo trabalhador. A ausência desta organização, entendida como um conjunto de meios e de estrutura necessários ao exercício de um determinada atividade, corresponde à inserção do trabalhador na empresa ${ }^{65}$.

Quanto ao vínculo de horário, tem-se que a existência de um horário pré fixado para a execução da prestação de trabalho não é, por si só, relevante para a caracterização do trabalho subordinado, mas coordenado com outros elementos, pode ser tido como manifestação do poder diretivo do empregador ${ }^{66}$.

Por fim, embora no passado a referência à vontade das partes fosse desprovida de qualquer valor, nos últimos anos tem ganhado relevância. A mais recente jurisprudência da Corte de Cassação italiana é orientada a atribuir uma notável importância, não tanto ao nome jurídico escolhido pelas partes, mas à vontade destas. Ou seja, embora na interpretação do contrato se deva verificar como a relação é desenvolvida em concreto, independentemente do nomen iuris, não necessariamente será descartado o exame da vontade das partes para fins de determinação do conteúdo do contrato em si mesmo. Isto não significa que as partes podem se valer, conforme queiram, da subordinação ou da autonomia ${ }^{67}$.

A dificuldade de se chegar a uma definição jurídica da relação em causa, nas hipóteses em que subsistem elementos compatíveis ao trabalho autônomo e ao subordinado e nas situações que envolvem novas profissões que carecem de homogeneidade social e econômica, tem levado a jurisprudência italiana a perquirir a vontade das partes. Deve-se ter em conta a confiança recíproca das partes e da concreta disciplina jurídica desejada por elas no exercício da autonomia contratual. Assim, se as partes, ao regularem seus interesses recíprocos, declararam a vontade de excluir a subordinação, não é possível, principalmente nas situações em que se verificam a presença de elementos de autonomia e de subordinação, chegar a conclusão diversa. A declaração de vontade das partes apenas se torna irrelevante diante da verificação majoritária da subordinação nos elementos da relação. As modalidades concretas de desenvolvimento da relação devem ser compatíveis com o intento declarado já que uma eventual discordância

65 GARATTONI, Marina. Op. cit., p. 27.

66 Ibidem, p. 25.

67 Ibidem, p. 27-30. 
esboça uma hipótese de simulação ou fraude com suas consequências jurídicas. A vontade das partes não substitui a busca das características intrínsecas da subordinação ${ }^{68}$.

De todo o exposto, tem-se que a operação de qualificação mediante a interpretação de indícios pode somente consistir em um juízo de aproximação (e não em um juízo subsuntivo ou de correspondência biunívoca), já que é sabido ser impossível uma completa identidade entre a relação concreta e a disposição legal. Em outras palavras, o procedimento de qualificação consiste no enquadramento ao tipo legal das situações concretas que apresentam as maiores ou as mais significativas (e não necessariamente a totalidade) características encontráveis no modelo socialmente prevalente de trabalhado subordinado previsto pelo legislador ${ }^{69}$. Isto porque, cada um dos elementos, tomado de per si, reveste-se de patente relatividade. Assim, deve-se proceder a um juízo de globalidade, comparando-se o tipo legal do trabalho subordinado à relação concreta que se apresenta ${ }^{70}$.

Pedro Romano Martinez, ao discorrer sobre os critérios que podem ser utilizados para a caracterização de uma relação de emprego, coloca que a interpretação da vontade das partes é fundamental para a referida qualificação. Ressalta que a utilização do método tipológico (enquadramento da relação jurídica ao tipo legal) quando associado a uma tipificação social, facilmente acarreta um excessivo alargamento do campo de aplicação do direito do trabalho, quase inviabilizando a existência dos contratos de prestação de serviços. Assim, este método tipológico deve se ater ao elemento essencial do contrato de emprego, qual seja, a subordinação jurídica. Pode ser utilizado, também, o método indiciário, que exige uma apreciação em conjunto dos indícios negociais internos (horário de trabalho, local de prestação de serviços, tipo de remuneração, utilização de bem ou utensílios fornecidos pelo empregador etc) com os indícios negociais externos (desenvolvimento da mesma atividade para diferentes beneficiários, tipo de imposto pago

68 GALANTINO, Luisa. Op. cit, p. 10-11.

69 CARINCI, Franco, TAMAJO, Raffaele de Luca, TOSI, Paolo, TREU, Tiziano. Op. cit., p. 18-21. Referido autor coloca que são insistentes as tentativas de atrelar a subordinação aos vários contornos da condição socioeconômica do trabalhador, valorizando aspectos que são externos à estrutura típica como inerência da atividade laborativa ao ciclo produtivo, debilidade econômica, etc. Essas tentativas são falhas, pois se tratam de perfis variáveis historicamente, estranhos aos tipo legal e desprovidos de idoneidade qualificadora. Complementa, ainda que, subsidiariamente ao critério de qualificação utilizado pela jurisprudência, considera-se o nomem iuris atribuído pelas partes à relação em análise, pesquisando-se a vontade das partes. Mas não se trata de negociar a imperatividade da norma legal, que deve incidir quando verificados os elementos da subordinação.

70 FERNANDES, António Monteiro. Direito do Trabalho. Décima terceira edição. Coimbra: Almedina, 2006, p. 146. GALANTINO, Luisa. Op. cit., p. 08. 
pelo prestador da atividade etc) ${ }^{71}$.

Na Alemanha, a jurisprudência assume um papel relevante na medida em que falta uma definição legislativa explícita de trabalhador subordinado. Assim, o Tribunal Federal do Trabalho (Bundesarbeitsgericht $=$ BAG) define o trabalhador subordinado considerando os seguintes elementos: a) a existência de um contrato como base (jurídica); b) realização de um serviço a outro sujeito; c) existência de dependência pessoal. O grau desta dependência depende do modo de inserção do trabalhador na organização empresarial, entendida como dependência em relação às diretrizes do empregador acerca da modalidade, do tempo e do lugar da prestação. A jurisprudência identifica numerosos indícios para as diversas figuras profissionais cada qual podendo assumir, no caso concreto, um peso maior ou menor ${ }^{72}$.

Nossa doutrina nacional coloca que o trabalho subordinado típico corresponde à relação de emprego, sendo o empregado definido como a pessoa física ${ }^{73}$ que presta serviços de natureza não-eventual a empregador, sob a dependência deste e mediante salário (artigo $3^{\circ}$, caput, da $\mathrm{CLT}^{74}$ ). Os requisitos caracterizadores de uma relação de emprego são: pessoalidade (o contrato é intuito personae, realizado com certa e determinada pessoa que não pode se fazer substituir), alteridade (o empregado presta serviços por conta alheia, sem assunção de qualquer risco), não eventualidade, onerosidade e subordinação ${ }^{75}$.

A subordinação é nota que o caracteriza, mas também pode estar presente em outros tipos de trabalho como o eventual, o intermitente, o avulso e o temporário (trabalho subordinado atípico) ${ }^{76}$.

71 MARTINEZ, Pedro Romano. Direito do trabalho. 4a . ed. Coimbra: Almedina, 2007, p. 312-318.

72 KEMPEN, Otto Ernst, KRETZSCHMAR, Robert. Os problemas e as dificuldades de organizar sindicalmente os trabalhadores semiautônomos na Alemanha. In RENAULT, Luiz Otávio Linhares [et al]. Parassubordinação: em homenagem ao Professor Marcio Tulio Viana. São Paulo: Ltr, 2011, p. 263264.

73 O trabalho deverá ser prestado pela pessoa física, não se admitindo pessoa jurídica (PEREIRA, Leone. Pejotização: o trabalhador como pessoa jurídica. São Paulo: Saraiva, 2013, p. 51; DELGADO, Mauricio Godinho. Curso de direito do trabalho. $5^{\text {a }}$.ed. São Paulo: LTr, 2006, p. 291).

74 Art. $3^{\circ}$, CLT: Considera-se empregado toda pessoa física que prestar serviços de natureza não eventual a empregador, sob a dependência deste e mediante salário.

Parágrafo único: Não haverá distinções relativas à espécie de emprego e à condição de trabalhador, nem entre o trabalho intelectual, técnico e manual.

75 MARTINS, Sergio Pinto. Direito do Trabalho. $18^{\mathrm{a}}$ ed.. São Paulo: Atlas, 2003, p. 107-108; PEREIRA, Leone. Op. cit., p. 50; DELGADO, Mauricio Godinho. Curso de direito do trabalho. 5a.ed. São Paulo: LTr, 2006, p. 290.

76 NASCIMENTO, Amauri Mascaro. Curso de direito do trabalho: história e teoria geral do direito do 
Predomina, também, o entendimento de que a subordinação é um fenômeno jurídico derivado do contrato estabelecido entre trabalhador e tomador de serviços, pelo qual o primeiro acolhe o direcionamento objetivo do segundo sobre a forma de efetuação da prestação de trabalho. É um reflexo do poder de direção do empregador que atinge, portanto, a forma de realização do trabalho e não a pessoa do trabalhador (prisma objetivo) $)^{77}$.

Ficam afastadas, assim, posições anteriores que consideravam a subordinação ora como sendo dependência econômica, ora como sendo dependência técnica (ou tecnológica).

A subordinação como dependência econômica pressupunha que o empregado necessita do trabalho e do salário para sobreviver, considerando sua hipossuficiência no plano econômico. Recebeu críticas por se fundamentar em um elemento extrajurídico e por não considerar situações em que o empregado eventualmente possua capacidade econômico financeira e não necessite do trabalho para sua sobrevivência ${ }^{78}$.

Antonio Monteiro Fernandes coloca que a dependência econômica se revela por dois traços fundamentais que geralmente estão associados. São eles: o fato de que quem realiza o trabalho, exclusiva e continuamente para certo beneficiário, encontra na retribuição o seu único e principal meio de subsistência (dependência da economia do trabalhador perante a do mesmo beneficiário) e o fato de que a atividade exercida, ainda que em termos de autonomia técnica e jurídica, se insere em um processo produtivo dominado por outrem (dependência sob o ponto de vista da estrutura do processo).

Esclarece o autor que pode existir dependência econômica sem subordinação jurídica, como no caso de um trabalhador autônomo, que exerce sua atividade em estabelecimento próprio, mas o produto de sua atividade se insere em um processo produtivo mais amplo, promovido ou dominado por certa entidade. Por outro lado, pode não existir dependência econômica em um trabalho subordinado, como, por trabalho: relações individuais e coletivas do trabalho. $24^{\mathrm{a}}$ edição, revista, atualizada e ampliada. São Paulo: Saraiva. 2009, p. 462.

77 DELGADO, Mauricio Godinho. Op. cit., p. 300-303; SILVA, Homero Batista Mateus da. Op. cit., p. $27-$ 29, SÜSSEKIND, Arnaldo. Instituições de Direito do Trabalho. Volume I. $22^{\mathrm{a}}$ ed.. atual. São Paulo: Ltr, 2005, p. 244-246; ROBORTELLA, Luis Carlos Amorim, PERES, Antonio Galvão. Op. cit, p. 118-119.

78 PAROSKI, Mauro Vasni, FERREIRA, Cícero Pedro. Subordinação na relação de emprego e a necessidade de sua releitura nas sociedades contemporâneas. In Revista Ltr, vol. 76, $\mathrm{n}^{\circ} 05$, maio 2012, $\mathrm{p}$. 586. 
exemplo, um médico empregado no serviço de saúde de uma empresa, mas que tem seu rendimento auferido, essencialmente, de atividade desempenhada em seu consultório ${ }^{79}$.

Já a subordinação como dependência técnica decorre da concepção de que o empregador monopoliza, naturalmente, o conhecimento necessário ao processo de produção em que se encontra inserido o empregado. No entanto, na empresa moderna, o empregador contrata o saber justamente por não o possuir. Ele organiza os meios de produção, sendo que a tecnologia é desenvolvida por seus empregados, sem ter a pretensão de absorver tais conhecimentos. É o que Alice Monteiro de Barros chama de "subordinação técnica invertida", já que, muitas vezes, a contratação recai sobre pessoas que detêm conhecimento relacionado a certa profissão (know-how) sendo que o empregador não possui este saber $^{80}$.

A subordinação gera direitos e deveres para ambos os contratantes. Ao empregador há o direito de direção e de comando, cabendo-lhe determinar as condições para a utilização e aplicação concreta da força de trabalho do empregado, nos limites do contrato; há o direito de controle, que consiste em verificar o exato cumprimento da prestação de trabalho e o direito de aplicar penas disciplinares. Ao direito do empregador de dirigir e comandar a atuação do empregado corresponde o dever de obediência por parte deste e, ao direito de controle correspondem aos deveres de obediência, diligência e fidelidade. Cabe notar que este dever de obediência apresenta limitações determinadas pelo contrato, sendo que pode o empregado se recusar a cumprir ordem ilegal, ilícita, de execução extraordinariamente difícil, que o sujeite a risco ou que fuja à natureza do contrato firmado ${ }^{81}$.

Homero Batista Mateus da Silva fala em graus de subordinação. Considerando que alguns graus de submetimento existem tanto nas relações civis como nas

79 FERNANDES, António Monteiro. Op. cit., p. 138-139. O critério da dependência econômica não é um conceito novo, já que sempre competiu com a concepção de subordinação jurídica. No entanto, hoje aparece reformulado e vem sendo defendido como elemento a ser utilizado para a aplicação do Direito do Trabalho. No entanto, não parece que a dependência econômica possa ser, por si mesma e de maneira absoluta, um critério único para determinar o âmbito de aplicação do Direito do Trabalho. Isto porque não se ignora a existência de casos em que pessoas prestam serviços de maneira verdadeiramente autônoma, mas que dependem economicamente de uma empresa. O desenvolvimento destas atividades ocorre de forma tal que não se permite afirmar a existência de uma relação de emprego. É o que ocorre com os chamados trabalhadores autônomos com dependência econômica (URIARTE, Oscar Ermida, ALVAREZ, Oscar Hernández. Op. cit., p. 212-213).

80 Op. cit., p. 284-285.

81 SÜSSEKIND, Arnaldo [et al.]. Instituições de Direito do Trabalho. Volume I. 22 $2^{\mathrm{a}}$ ed.. atual. São Paulo: Ltr, 2005, p. 246-248. 
comerciais, não sendo, portanto, exclusivos do Direito do Trabalho, o que diferencia a subordinação jurídica trabalhista das demais formas de subordinação é a sua intensidade. Assim, a relação de emprego caracteriza-se por uma subordinação em grau máximo, as formas de trabalho autônomo são dotadas de uma subordinação em grau médio e as relações civis mais fugazes de uma subordinação em grau mínimo. Este posicionamento poderia ser representado por círculos concêntricos de sorte que o núcleo duro destes seria a subordinação mais intensa, própria do contrato de trabalho. A partir deste, surgem outros círculos que envolvem uma quantidade maior de pessoas com uma subordinação menos acentuada, até o completo desaparecimento desta ${ }^{82}$. Portanto, observa-se o modo como o trabalho é prestado já que a mesma profissão pode ser exercida de modo subordinado ou autônomo, dependendo das circunstâncias em que se efetivar o trabalho ${ }^{83}$.

Cabe mencionar a existência de posição doutrinária que propõe uma releitura do conceito de subordinação ao considerar insuficiente a ideia tradicional de subordinação controle ou subjetiva, eis que, diante da realidade atual, os atos de comando se diluem na estrutura da empresa à medida em que o trabalho se tecniciza e se intelectualiza. Fala-se em subordinação objetiva ou subordinação integração que se revela nas situações em que a atividade exercida pelo empregado se integra e se incorpora na atividade empresarial, compondo a dinâmica geral da empresa. A atividade do trabalhador mostra-se indispensável para o alcance dos objetivos empresariais. Conforme este posicionamento, a subordinação decorre do fato de o trabalhador se integrar em uma organização de meios produtivos alheios, dirigida à obtenção de fins alheios o que leva à submissão às regras que exprimem o poder de organização do empresário ${ }^{84}$.

De acordo com Mauricio Godinho Delgado, este posicionamento não se firmou no meio jurídico. Por ser amplo, não permitia a distinção, na prática, entre os trabalhos autônomo e subordinado, principalmente quando a prestação de serviços se realizava fora da planta empresarial. Na realidade, sua formulação permitia que situações fáticas eminentemente autônomas fossem enquadradas como subordinadas, o que

82 Op. cit., p. 30-31.

83 NASCIMENTO, Amauri Mascaro. Curso de direito do trabalho: história e teoria geral do direito do trabalho: relações individuais e coletivas do trabalho. $24^{\mathrm{a}}$ edição, revista, atualizada e ampliada. São Paulo: Saraiva. 2009, p. 462-463.

84 PORTO, Lorena Vasconcelos. A subordinação no contrato de trabalho: uma releitura necessária. São Paulo: Ltr, 2009, p. 68-70. 
contribuiu para seu desprestígio ${ }^{85}$.

Referido autor apresenta o conceito de subordinação estrutural, que é definida como aquela que se manifesta pela inserção do trabalhador na dinâmica do tomador dos serviços, independentemente de receber ou não ordens diretas deste ${ }^{86}$.

Alice Monteiro de Barros coloca que a integração do trabalhador na organização da empresa não representa um critério autônomo para indicar a existência de uma relação de emprego, mas um fundamento teórico para a conceituação do trabalhador subordinado. A participação integrativa do trabalhador no processo produtivo deve acarretar a submissão do trabalhador às diretivas do empregador e ao poder disciplinar. Informa que na doutrina moderna italiana predomina o entendimento de que a inserção ou integração da atividade laborativa do trabalhador na organização empresarial não é um critério suficiente, pois pode ocorrer também nos casos de trabalho autônomo ${ }^{87}$.

Ao abordar a concepção de subordinação objetiva ou estrutural, Yone Frediani coloca ser temerária sua aplicação ao trabalho autônomo e aos contratos atípicos de prestação de serviços, caracterizando tais situações como trabalho subordinado apenas pelo fato de o prestador se inserir na estrutura administrativa de produção ou de distribuição de bens da contratante, mesmo sem receber ordens de maneira direta ou indireta $^{88}$.

Ao longo do século XX até 1970, verificou-se uma tendência de expansão da noção de subordinação. Entretanto, a partir de 1980 há uma mudança de posicionamento da doutrina, jurisprudência e do legislador, que passaram a adotar uma orientação mais restrita ${ }^{89}$.

A concepção tradicional de subordinação controle se revelou como critério mais seguro para caracterização da relação de emprego, o que não obsta, como será abaixo desenvolvido, uma releitura do Direito do Trabalho para que este passe a alcançar outras formas de relação de trabalho.

Conforme já mencionado anteriormente, a globalização acarretou

${ }_{85}$ Direitos fundamentais na relação de trabalho. In Revista Ltr, vol 70, nº 06, junho de 2006, p. 667.

${ }^{86}$ Op. cit, p. 667.

${ }^{87}$ Curso de Direito do Trabalho. Curso de Direito do Trabalho. $6^{\text {a }}$ ed. São Paulo: Ltr, 2010, p. 284-287 e 301.

88 A quem o Direito do Trabalho deve proteger e o novo conceito de subordinação. In FILHO, Jorge Cavalcanti Boucinhas, BERARDO, Carlos Francisco (organizadores). Novos dilemas do trabalho, do emprego e do processo do trabalho. São Paulo: Ltr, 2012, p. 61.

89 PORTO, Lorena Vasconcelos. Op. cit., p. 94. 
mudanças no trabalho desenvolvido na empresa e fora dela. Ressalta-se, assim, a passagem de uma realidade socioeconômica na qual a relação de trabalho subordinado por tempo indeterminado constituía a forma de ocupação prevalente para uma diversa realidade na qual este tipo de relação não se mostra mais hegemônica. Certamente, a relação de trabalho subordinado permanece, obviamente, como sendo a relação de trabalho mais significativa para o aparato normativo, bem como ainda constitui forma significativa de contratação na sociedade, mas se observa que, fora deste âmbito, vem crescendo de forma vistosa uma série de relações de trabalho autônomo ${ }^{90}$.

Percebe-se uma heterogeneidade no mercado de trabalho uma vez que a relação de emprego não é mais a modalidade contratual monopolizadora da prestação de serviços, ampliando-se as formas de contratação do trabalho, com a revalorização dos contratos civis o que exige a retomada do diálogo entre Direito Civil e Direito do Trabalho 91. Percebe-se, assim, que a tendência tradicional de recondução dos vínculos laborais a um único modelo vai sendo atenuada, paulatinamente, por uma tendência de diversificação dos vínculos laborais. Aliás, conforme acima mencionado, o posicionamento da jurisprudência italiana, ao considerar a autonomia da vontade das partes, indica que o trabalho subordinado vem perdendo sua vis attractiva que vinha exercitando nos confrontos das situações dúbias de interpretação ${ }^{92}$.

\subsection{Trabalho Autônomo.}

Recentemente, assiste-se a um incremento das formas de trabalho autônomo, em razão do novo modelo empresarial que se tem desenhado, com contornos diferentes daqueles em que o Direito do Trabalho dos anos 60 entendia como empresa ${ }^{93}$. A saída do mercado de trabalho subordinado e o ingresso ao autônomo pode ser verificada pela ausência de oportunidades de trabalho subordinado, pela exigência da empresa de

90 SANTORO-PASSARELLI, Giuseppe. Globalizzazione e lavoro subordinato. In Roma e America. Diritto Romano Comune, Rivista di Diritto dell'Integrazione e Unificazione del Diritto in Europa e in America Latina, Roma, Itália, n. 15, 2003, p. 225

91 ROBORTELLA, Luis Carlos Amorim, PERES, Antonio Galvão. Op. cit., p. 122.

92 GALANTINO, Luisa. Op. cit., p. 12.

93 MARTINEZ, Pedro Romano. Exigências de um novo direito do trabalho. In MARTINS, Ives Gandra da Silva, CAMPOS, Diogo Leite de (coordenadores). O direito contemporâneo em Portugal e no Brasil. São Paulo: Saraiva, 2004, p. 377. 
utilizar uma forma de trabalho flexível, pela própria vontade do trabalhador impulsionado por uma perspectiva de obter maiores ganhos, de ter valorização profissional e maior liberdade de gerir seu tempo de trabalho. Menciona-se, ainda, a excessiva rigidez da disciplina do trabalho subordinado ${ }^{94}$.

De acordo com Otavio Pinto e Silva, as origens remotas do trabalho autônomo podem ser apontadas no direito romano em sua regulamentação da prestação de serviços. A locação (locatio conductio) era o contrato pelo qual alguém, mediante remuneração (merces) se obrigava a : a) proporcionar a outrem o uso, ou o uso e o gozo de uma coisa (locatio conductio rei); b) a prestar um serviço a outrem (locatio conductio operarum); c) realizar uma obra para outrem (locatio conductio operis) ${ }^{95}$.

Assim, ensina referido autor que, na locatio conductio operis, o locator entregava ao conductor uma ou mais coisas que servissem de objeto de trabalho que este se obrigava a realizar àquele. $\mathrm{O}$ objeto de contrato, portanto, era o material que o dono da obra entregava para a realização da obra contratada. Isto porque se o próprio empreiteiro fornecesse o material, caraterizar-se-ia uma compra e venda (emptio venditio). $\mathrm{O}$ conductor, que deveria observar as normas técnicas necessárias para que a obra atingisse o objetivo considerado, não se obrigava ao trabalho, mas sim ao resultado final da obra a realizar. O conductor respondia pelas coisas recebidas, como pelo seu perecimento ou sua custódia. Sua responsabilidade cessava após a aprovação da obra pelo locator e o pagamento da merces ocorria após o término da obra, salvo disposição contrária das partes.

$\mathrm{Na}$ locatio conductio operarum, o locator se obriga a prestar serviços ao conductor, com abstração do resultado final (locare operas suas). A prestação de serviços era personalíssima, ou seja, deveria ser efetuada pessoalmente pelo locator, extinguindo-se o contrato com sua morte. Os serviços prestados eram aqueles costumeiramente atribuídos aos escravos.

94 SANTORO-PASSARELLI, Giuseppe. Globalizzazione e lavoro subordinato. In Roma e America. Diritto Romano Comune, Rivista di Diritto dell'Integrazione e Unificazione del Diritto in Europa e in America Latina, Roma, Itália, n. 15, 2003, p. 231-232.

95 Subordinação, autonomia e parassubordinação nas relações de trabalho. São Paulo: LTr, 2004, p. 8387. De acordo com Thomas Marky, a distinção mencionada é fruto dos intérpretes modernos, eis que não conhecida pelo direito romano clássico, e se fundamenta nas três espécies diversas do objeto do contrato (Curso elementar do direito romano. $8^{\mathrm{a}}$ ed. São Paulo: Saraiva, 1995, p. 127). No Direito Moderno, a locatio rei, locatio operarum e locatio operis faciendi foram disciplinadas sob os nomes, respectivamente, de locação de coisa, locação de serviços e empreitada ou locação de obra, rompendo-se a unidade conceitual (GOMES, Orlando. Contratos. Rio de Janeiro: Forense, 1999, p. 272). 
Destes elementos, conclui o autor que, na locatio operis, o risco é integralmente do trabalhador, que se obriga a prestar a obra pronta (opus perfectum), qualquer que seja o custo suportado para se alcançar o resultado. Por outro lado, na locatio operarum, o risco do resultado é do empreendedor, pois o trabalhador se obriga a prestar a sua energia limitando-se a suportar apenas o perigo da falta ou impossibilidade do trabalho. Considerando que, modernamente, o critério de subordinação ou dependência foi desenvolvido visando afastar as incertezas decorrentes do risco do trabalho, gradualmente o contrato de trabalho subordinado foi se destacando da locatio conductio rei et operis, ao passo que o trabalho autônomo manteve as ligações com as origens de sua regulamentação.

De acordo com Amauri Mascaro Nascimento, existem diferentes teorias que visam definir o trabalho autônomo, conforme se descreverá abaixo ${ }^{96}$.

Primeiramente, menciona-se a teoria do risco que caracteriza o trabalhador autônomo pelo fato de assumir o risco da atividade que exerce ao passo que, no trabalho subordinado, o ônus cabe ao destinatário do trabalho. O que se observa é que, embora esta teoria possa fornecer elementos indicativos, não pode ser acolhida de forma absoluta pois há, na legislação trabalhista, disposições que remetem ao empregado os riscos do empreendimento como a redução geral do salário diante de força maior.

Aponta-se, também, a chamada teoria da propriedade dos instrumentos de trabalho, que considera autônomo aquele que exerce atividade profissional detendo os meios de produção que são de sua propriedade. Neste aspecto, também se levantam algumas dúvidas pois, em certas situações, alguns empregados possuem os instrumentos de trabalho, como o jardineiro que é dono da tesoura de cortar grama, não obstante prestem serviços como empregados.

De acordo com a teoria do resultado do trabalho, se este for imediato, de sorte que o trabalhador tem o resultado primeiro e fica com o que produz, será autônomo. Porém, se o resultado for mediato, isto é, o trabalhador aliena o que faz apenas recebendo um preço ou pagamento, será considerado como subordinado.

Pela teoria da relação entre o trabalho e a remuneração, o trabalhador será autônomo se a remuneração é contratada tendo em vista o pagamento do resultado e

96 NASCIMENTO, Amauri Mascaro. Curso de direito do trabalho: história e teoria geral do direito do trabalho: relações individuais e coletivas do trabalho. $24^{\mathrm{a}}$ edição, revista, atualizada e ampliada. São Paulo: Saraiva. 2009, p. 459-463. 
subordinado se a remuneração se destina a pagar o trabalho. No entanto, referido posicionamento se lastreia em critério não decisivo para a fixação da distinção.

Finalmente, menciona-se a teoria da determinação ou indeterminação prévia das prestações singulares, sendo autônomo o primeiro e subordinado o segundo. A diferença entre trabalho subordinado e autônomo está no modo como o trabalho é realizado. Desta maneira, aqueles que detêm o poder de direção da própria atividade, autodisciplinando-a, são autônomos. Já aqueles que alienam, volitivamente, como exercício de uma liberdade, mediante contrato, o poder de direção de sua atividade para terceiros em troca de salário são considerados subordinados.

A Lei 8.213/91, que versa sobre o Plano de Benefícios da Previdência Social, define o trabalhador autônomo como sendo a pessoa física que exerce, por conta própria, atividade econômica de natureza urbana, com fins lucrativos ou não (art. 11, inc. V, alínea g). Trata-se de segurado obrigatório do Regime Geral da Previdência Social, inserido dentro da categoria dos contribuintes individuais.

Critica-se esta definição na medida em que o trabalho autônomo também pode ser realizado em atividades rurais ${ }^{97}$.

O trabalho autônomo não consiste em uma figura unitária, já que representa um universo não delimitado de atividades econômico produtivas e profissionais desenvolvidas sem subordinação e com trabalho prevalentemente próprio ${ }^{98}$.

O trabalho autônomo afasta-se da relação de emprego essencialmente pela ausência do elemento subordinação, entendida como critério objetivo relacionado ao modo de concretização do trabalho pactuado ${ }^{99}$. Nota-se, entretanto, que a autonomia é compatível com a sujeição do trabalhador às diretrizes de caráter geral fixadas pelo contratante com a finalidade de adequar a prestação às suas exigências funcionais ${ }^{100}$.

97 MARTINS, Sergio Pinto. Direito do trabalho. $18^{\mathrm{a}}$ ed. São Paulo: Atlas, 2003, p. 165.

98 PERULLI, Adalberto. Lavoro Autonomo e dipendenza economica, oggi. In Rivista Giuridica del lavoro e della Previdenza Sociale, anno LIV, 2003, n. 2, aprile/giugno 2003, p. 221-222.

Jorge Luiz Souto Maior reconhece a existência de diversos níveis de trabalhadores autônomos. Há aqueles que trabalham por conta própria e são possuidores de bens, insumos e capital para a realização de sua atividade econômica, vendendo o seu trabalho direta e livremente no mercado, como acontece com os profissionais liberais. Há, ainda, aqueles que não detêm os elementos necessários para o desenvolvimento de sua atividade, ou os possuem de forma precária. Estes são conhecidos como trabalhadores eventuais (Relação de emprego e direito do trabalho: no contexto da ampliação da competência da Justiça do Trabalho. São Paulo: Ltr, 2007, p. 74).

99 DELGADO, Mauricio Godinho. Curso de direito do trabalho. $5^{\mathrm{a}}$.ed. São Paulo: LTr, 2006 , p. 334.

100 GALANTINO, Luisa. Op. cit., p. 09. 
Para Paulo Emílio Ribeiro de Vilhena, autônomo é o trabalhador que desenvolve sua atividade com organização própria, iniciativa e discricionariedade, além da escolha do lugar, do modo, do tempo e da forma de execução. A iniciativa e auto organização enfatizam a liberdade de o prestador dispor de sua atividade a mais de uma pessoa. A pluralidade de credores é ínsita no trabalho autônomo, porém, cabe notar que a exclusividade não acompanha necessariamente a subordinação ${ }^{101}$.

Além da ausência da subordinação, pode haver, também, a ausência de pessoalidade, conforme já mencionado. Neste caso, a fungibilidade da pessoa física do prestador permite que essa modalidade de prestação de serviço seja pactuada com pessoas jurídicas. Assim, é característica da relação jurídica ajustada a substituição e alteração do profissional que efetivamente produz o serviço contratado. Isto pode ser observado na prestação de serviços de consultoria, contabilidade, desde que não seja relevante que determinada atividade seja desempenhada por um específico profissional. Por outro lado, o trabalho autônomo também pode ser contratado com cláusula de rígida pessoalidade, como ocorre com trabalho a ser desempenhado por profissionais que detêm um conhecimento mais especializado, como médicos, advogados, artistas, etc ${ }^{102}$.

Importante notar que o autônomo desenvolve sua atividade sem subordinação a horário, livre da fiscalização do destinatário de seus serviços e, eventualmente, com o auxílio de terceiros, se lhe convier. Assim, dois elementos para a sua caracterização são inciativa e a auto-organização ${ }^{103}$. Além disso, o trabalho propriamente autônomo não se vincula ou se insere continuamente na atividade do contratante ${ }^{104}$.

Pedro Romano Martinez coloca que há duas razões que justificam o recurso ao trabalho autônomo. A primeira delas é impulsionada por um motivo fraudulento, visando afastar a aplicação das normas imperativas de Direito do Trabalho. A segunda razão é a própria constituição de uma relação de trabalho autônomo lícita. Neste caso, a qualificação jurídica da relação dada pelas partes é baseada em um motivo lícito, sendo o enquadramento pretendido justificado por razões técnicas (como o modo de prestar a atividade) ou por motivos conjunturais, principalmente derivados da necessidade de as

${ }_{101}$ Relação de emprego: estrutura legal e supostos. $3^{\mathrm{a}}$ ed. São Paulo: Ltr, 2005, p. 531-534.

102 DELGADO, Mauricio Godinho. Curso de direito do trabalho. $5^{\text {a }}$.ed. São Paulo: LTr, 2006, p. 335.

${ }^{103}$ SILVA, Otavio Pinto e. Subordinação, autonomia e parassubordinação nas relações de trabalho. São Paulo: Ltr, 2004, p. 91.

104 OLIVEIRA, Murilo Carvalho Sampaio. Subordinação jurídica: um conceito desbotado. In Revista dos Tribunais on line. Thomson Reuters, p. 23. 
empresas se adaptarem à competitividade e aos novos métodos. Verifica-se, portanto, o surgimento e uma nova estrutura empresarial com poucos trabalhadores e muitos prestadores de serviços ${ }^{105}$.

É importante notar que as novas formas de organização da produção são cada vez mais dependentes do conhecimento individual e, quando este viés intelectual é valorizado, o trabalhador acaba detendo parcela decisiva dos meios e dos modos de produção, comprometendo uma visão dicotômica entre subordinação e autonomia. Assim, quanto maior o nível de profissionalização e de qualificação, maior o espaço de autonomia para a realização do trabalho, ou seja, a subordinação tende atenuar-se cada vez mais avizinhando-se de uma genérica supervisão encontrável também nas relações de trabalho autônomo $^{106}$.

Esclarece-se que pode ser objeto de uma relação de emprego atividades cuja natureza implica a absoluta garantia da autonomia técnica do empregado (v.g., médicos, advogados). Mas, nesses casos, há uma dificuldade em se identificar se há uma relação de emprego ou uma relação de trabalho autônomo. Tendo em consideração a natureza de tais profissões, deve-se presumir que os negócios que têm como objeto tais atividades são contratos de prestação de serviços, ou seja, relação de trabalho autônomo ${ }^{107}$.

Diante da tendência de valorização do trabalho autônomo, mostra-se desarrazoado presumir a existência de relação de emprego, principalmente quando se está diante de formas de contratação expressamente contempladas na legislação civil, no direito societário ou empresarial ${ }^{108}$. Aliás, a própria legislação admite a contratação de serviços intelectuais, para fins previdenciários e fiscais por meio de pessoa jurídica (artigo 129, Lei 11.196/2005), apoia e estimula o cooperativismo (artigo 174, par. 2, da CF, Lei 5764/71, artigo 442, par. 1, da CLT), permite a contratação de estagiários e regula as mais diversas formas de prestação de serviços (art. 593 e seguintes do CC).

105 Exigências de um novo direito do trabalho. In MARTINS, Ives Gandra da Silva, CAMPOS, Diogo Leite de (coordenadores). O direito contemporâneo em Portugal e no Brasil. São Paulo: Saraiva, 2004, p. 364365. O trabalho autônomo pode enquadrar-se em diversas figuras negociais, principalmente os contratos de prestação de serviço, de mandato, de agência ou de empreitada.

106 ROBORTELlA, Luis Carlos Amorim, PERES, Antonio Galvão. Op. cit., p. 120-122. FERNANDES, António Monteiro. Op. cit., p. 137.

107 FERNANDES, António Monteiro. Op. cit., p. 138. Luisa Galantino, ao fazer referência à posição adotada pela jurisprudência italiana, coloca que a relação entre o médico e uma clínica particular pode ser definida como subordinada se o médico é submetido a um controle sobre a intrínseca execução da prestação, com consequente limitação de sua liberdade e autonomia (Op. cit., p. 09)

108 ROBORTELLA, Luis Carlos Amorim, PERES, Antonio Galvão. Op. cit., p. 120-122. 
As formas de atividade autônoma podem ser desempenhadas tanto por uma pessoa física, como normalmente é feito pelos profissionais liberais, pequenos artífices, quanto podem ser desempenhadas sob a forma de pessoa jurídica, unipessoal ou não, microempresas ou não ${ }^{109}$, conforme será mais adiante analisado. A fraude, portanto, deve ser reconhecida apenas nas situações em que verdadeiramente se está diante de um trabalho em regime de subordinação ${ }^{110}$.

Por fim, cumpre notar que, nos últimos tempos, o mundo do trabalho independente sofreu algumas modificações. Sob os amplos processos de externalização da produção emergiram formas de trabalho autônomo que apresentam traços mais ou menos visíveis de dependência econômica, cuja existência torna-se perceptível por um grupo heterogêneo de indicadores como a personalidade da prestação, a longa duração da relação contratual, ausência de colaboradores, destinação da prestação a um único comitente, importância dos rendimentos percebidos de um parceiro dominante. Trata-se de uma nova fenomenologia do trabalho autônomo que passa a ser definida de diversas formas pelos intérpretes e até pelo legislador europeu: trabalho parassubordinado, pessoa assemelhada ao trabalhador subordinado, trabalho autônomo dependente, dependência na autonomia ${ }^{111}$, conforme será melhor analisado abaixo.

\subsection{Trabalho Parassubordinado.}

A partir da segunda metade do século XX, começam a surgir na Itália as primeiras discussões a respeito de uma necessária revisão do conceito de subordinação ante as modificações do processo produtivo provocadas pela Terceira Revolução Industrial.

109 SILVA, Homero Batista Mateus da. Op. cit., p.11-17. Historicamente, o trabalho autônomo tem sido heterogêneo e expressivo no Brasil. Sob a categoria de autônomo estão: o trabalho desqualificado e de baixo rendimento, o profissional especializado e de alto rendimento, o serviço em setores estruturados e em circuitos de alta renda, o serviço que tem como clientela a baixa renda, o serviço prestado à empresa (com ou sem tecnologia ou especialização), a consultoria, o teletrabalho, o pedreiro por conta própria, o motorista que adquiriu seus veículo, o motoboy, o publicitário, o free lance etc (KREIN, Jose Darin, PRONI, Marcelo Weishaupt. Economia informal: aspectos conceituais e teóricos. Série Trabalho Decente no Brasil. Documento de trabalho n.4. Escritório da OIT no Brasil. Brasilia: OIT, 2010, p. 31, disponível em http:/www.oit.org.br/sites/default/files/topic/employment/pub/economia informal 241.pdf, acesso 28.04.2012)

110 ROBORTELLA, Luis Carlos Amorim, PERES, Antonio Galvão. Op.cit., p. 122.

111 PERULLI, Adalberto. Lavoro Autonomo e dipendenza economica, oggi. In Rivista Giuridica del lavoro e della Previdenza Sociale, anno LIV, 2003, n. 2, aprile/giugno 2003, p. 222-223. 
Neste contexto, reconhece-se o surgimento de uma classe de trabalhadores que se situa em uma zona cinzenta entre a subordinação e a autonomia. Surge, então, a noção de parassubordinação, apelidada de "co.co.co" pelo fato de a atividade ser desenvolvida de forma colaborativa, continuativa e coordenada. Referido instituto contemplava dois grandes objetivos. O primeiro deles visava atender as demandas das empresas pela flexibilização das formas de trabalho, mediante a instituição das relações contratuais laborais que permitissem uma melhor adequação às modificações no mercado de trabalho. O segundo objetivo visava conferir adequada tutela jurídica a esta nova classe de trabalhadores em ascensão ${ }^{112}$.

A primeira menção ao trabalho parassubordinado pode ser encontrada em 1959, na Lei 741, de 14 de julho, que dispunha competir ao governo estabelecer normas jurídicas com força de Lei aptas a garantir uma tutela mínima das relações de colaboração que se concretizem em prestações de obra continuativa e coordenada ${ }^{113}$. Referida lei ficou conhecida popularmente como Lei Vigorelli (por ter sido proposta pelo então Ministro do Trabalho, Ezio Vigorelli) e vigorou por apenas um ano, eis que, em 1960, foi declarada inconstitucional pela Corte Constitucional. Apesar disto, teve como mérito inserir, no ordenamento italiano, a noção da co.co.co ${ }^{114}$.

A doutrina, porém, entende que o instituto da parassubordinação é consagrado com a promulgação da Lei 533/73, que estabelecia uma reforma no processo do trabalho (artigo 409, do Código de Processo Civil italiano) e aplicava o procedimento especial às relações continuativas e coordenadas ${ }^{115}$. Esta lei alterou radicalmente a disciplina do processo do trabalho, que substituiu todo o Título IV, do Livro II, do Codice di Procedura Civile, sendo que uma das maiores inovações foi exatamente a extensão do processo do trabalho às controvérsias relativas às "relações de agência"116, de representação

112 BULGUERONI, Renata Orsi. Parassubordinção: origem, elementos, espécies e tutela. In Revista de Direito de Trabalho, ano 34, n. 131, jul.-set./2008, p. 329. BATALHA, Elton Duarte. Necessidade de reforma trabalhista: a experiência italiana. In Revista de Direito de Trabalho, ano 34, n. 131, jul.set./2008, p. 309.

113 BULGUERONI, Renata Orsi, Parassubordinção: origem, elementos, espécies e tutela. In Revista de Direito de Trabalho, ano 34, n. 131, jul.-set./2008, p. 330.

114 BULGUERONI, Renata Orsi. Trabalho autônomo dependente: experiências italiana e espanhola e a realidade brasileira. Dissertação apresentada à banca examinadora da Faculdade de Direito da Universidade de São Paulo como exigência parcial para obtenção do título de Mestre em Direito do Trabalho e Seguridade Social. São Paulo, 2011, p. 61-62.

115 PESSOA, Flavia Moreira Guimarães. Relações de trabalho na sociedade contemporânea. São Paulo: Ltr, 2009 , p.79.

116 Ao considerar que o contrato de agência constitui o paradigma das relações de trabalho autônomo 
comercial e outras relações de colaboração que se concretizem em uma prestação de obra continuada e coordenada, prevalentemente pessoal, mesmo se em caráter não subordinado 117 ,

A reforma no processo de trabalho de 1973 separava um espaço dentro do qual se sabia reunir inúmeras e diversas manifestações de trabalho pessoal continuativas. Essas manifestações se situavam em uma zona cinzenta e buscavam, ainda que fora do âmbito da subordinação, um núcleo inicial de proteção mínima. As relações de colaboração selecionadas por meio da definição legal tinham, por base negocial, na maior parte dos casos, as prestações de conteúdo intelectual, além de outras formas como contratos associativos, cooperativos ou de associação em participação ${ }^{118}$.

O objetivo desta extensão foi a de garantir uma tutela processual célere e incisiva a todos os trabalhadores, subordinados ou autônomos, cujos rendimentos auferidos dependem de uma certa relação profissional ${ }^{119}$.

Assim, as prestações de trabalho autônomo podem ser efetuadas mediante formas de colaboração continuativas e coordenadas. Apresentam elemento de

continuativo e coordenado e de caráter pessoal, Giuseppe Santoro-Passarelli pontua que nem todos os contratos de agência podem ser incluídos nas disposições do artigo 409, n. 3, do CPC. Assim, nas situações em que a atividade do agente seja desenvolvida em forma de empresa e, portanto, a atividade pessoal do agente não seja prevalente em relação à organização, esta relação não se submete ao rito do trabalho (Diritto dei Lavori. Seconda edizione. Torino: G. Giappichelli Editore, 2004, p. 282)

117 Art. 409: Si osservano le disposizioni del presente capo nelle controversie relative a: 1) rapporti di lavoro subordinato privato, anche se non inerenti all'esercizio di una impresa; 2) rapporti di mezzadria, di colonia parziaria, di compartecipazione agraria, di affitto a coltivatore diretto, nonche' rapporti derivanti da altri contratti agrari, salva la competenza delle sezioni specializzate agrarie; 3) rapporti di agenzia, di rappresentanza commerciale ed altri rapporti di collaborazione che si concretino in una prestazione di opera continuativa e coordinata, prevalentemente personale, anche se non a carattere subordinato; 4) rapporti di lavoro dei dipendenti di enti pubblici che svolgono esclusivamente o prevalentemente attivita' economica; 5) rapporti di lavori dei dipendenti di enti pubblici ed altri rapporti di lavoro pubblico, sempreche' non siano devoluti dalla legge ad altro giudice.

(Disponível em http://www.altalex.com/index.php?idnot=33739 , acesso 26.03.2012).

118 PEDRAZZOLI, Marcello. Il modo delle collaborazioni coordinate e continuative fra genuinità e frode. In Il diritto del lavoro, Roma, Fondazione Diritto del Lavoro, maggio-agosto 2004, anno LXXVIII, p. 11781179.

119 PORTO, Lorena Vasconcelos. A subordinação no contrato de trabalho: uma releitura necessária. São Paulo: Ltr, 2009, p. 119. Giuseppe Santoro-Passarelli coloca que o legislador não visou, com o disposto no art. 409, n. 03 do CPC italiano, submeter estas relações ao tipo do trabalho subordinado, nem tampouco visou lhe atribuir uma função antifraudulenta, isto é, dirigida a tutelar relações que se desenvolvem de forma subordinada contrariando a declaração das partes. Na realidade, a norma processual, em homenagem à diversidade, entendeu que algumas relações, embora não subsumíveis ao trabalho subordinado, merecem receber a mesma tutela processual (Diritto dei Lavori. Seconda edizione. Torino: G. Giappichelli Editore, 2004, p. 287) 
semelhança com o trabalho subordinado por se desenvolverem, de regra, de modo continuativo e se integrarem, além de se coordenarem, com a atividade e os fins perseguidos pelo contratante. Por outro lado, o trabalhador conserva sua autonomia, na iniciativa e na gestão da prestação, mas permanece ligado ao contratante por um vínculo bem forte capaz de colocá-lo em uma condição de relativa inferioridade e fraqueza ${ }^{120}$.

O seu mérito foi o de representar uma cômoda alternativa ao trabalho subordinado, o que ensejou a prática de abusos, já que a parassubordinação era utilizada como forma de afastar as tutelas existentes do trabalhado subordinado ${ }^{121}$.

Visando coibir esta utilização desmedida, o legislador institui, através do Decreto-legislativo 276/2003 (conhecido como Reforma Biagi), a fattispecie do trabalho a projeto. Com isto, acrescenta-se um novo elemento para a determinação das relações de parassubordinação: o projeto, programa ou fase deste. Assim, as relações de colaboração continuativa e coordenada devem contemplar um projeto específico para a sua configuração. Considerando que o próprio texto do Decreto-legislativo 276/2003 exclui do âmbito de incidência do trabalho a projeto determinadas espécies de prestação de serviços, afirma-se que o instituto da parassubordinação é representado por duas espécies distintas de relações de colaboração: de um lado, as tradicionais "co.co.co", disciplinadas pelo artigo 409, n. 3, do CPC e, de outro, os novos contratos de trabalho a projeto, previstos pelo Decreto legislativo $276 / 2003^{122}$.

Mais especificamente, quando o Decreto Legislativo 276/03 exclui do âmbito de incidência do trabalho a projeto determinadas espécies de prestação de serviço, faz com que estas continuem sendo regidas pelo art. 409, n. 3, do Código de Processo Civil italiano. Essas exclusões se justificam pelo fato de que tais prestações de serviço não representam riscos à fuga das normas trabalhistas ${ }^{123}$.

${ }^{120}$ SCOGNAMIGLIO, Renato. Diritto del lavoro. Napoli: Casa Editrice Dott. Eugenio Jovene, 2000, p. 113.

${ }^{121}$ GALANTINO, Luisa. Op. cit., p. 22.

122 BULGUERONI, Renata Orsi. Parassubordinção: origem, elementos, espécies e tutela. In Revista de Direito de Trabalho, ano 34, n. 131, jul.-set./2008, p. 334.

123 BULGUERONI, Renata Orsi. Trabalho autônomo dependente: experiências italiana e espanhola e a realidade brasileira. Dissertação apresentada à banca examinadora da Faculdade de Direito da Universidade de São Paulo como exigência parcial para obtenção do título de Mestre em Direito do Trabalho e Seguridade Social. São Paulo, 2011, p. 95-97. Referida autora descreve atividades excluídas do trabalho a projeto. Exemplificativamente, citamos: contratos firmados com a Administração Pública, contratos de agência, de representação comercial, prestações ocasionais, entendidas como relações de duração não superiores a trinta dias no ano com o mesmo comitente, salvo se a remuneração percebida for superior a cinco mil euros, profissões intelectuais para cujo exercício seja necessária inscrição em ordens profissionais, co.co.co firmadas com entidades de promoção esportiva. 
No âmbito da parassubordinação, se incluem todas as formas de trabalho que, embora não expressamente definidas, apresentem os requisitos exigidos pela legislação, quais sejam, continuidade, coordenação e o caráter prevalentemente pessoal da prestação desenvolvida. Trata-se de uma série de relações que conservam suas disciplinas substanciais específicas integradas, no entanto, de uma série suplementar de normas de garantia. Não é relevante para a caracterização da parassubordinação a aferição da dependência econômica, já que a ausência de uma situação de sujeição socioeconômica não impede a aplicação de tutelas específicas desde que constatados os três elementos acima mencionados ${ }^{124}$.

A coordenação é o elemento mais difícil de ser interpretado já que pode ser confundido com a heterodeterminação, entendida como a submissão ao poder diretivo de empregador. De acordo com a jurisprudência da Corte de Cassação italiana, por coordenação se entende a ligação funcional da prestação com a estrutura do tomador e com a atividade principal desenvolvida por este de modo que a prestação possa se inserir em seu programa como meio para realizá-1o ${ }^{125}$. Entende-se que os resultados da atividade do colaborador devem se unir aos da atividade do tomador, considerando critérios qualitativos, quantitativos e funcionais. Se na subordinação a atividade do empregado se insere na organização da empresa de uma forma estrutural, na parassubodrdinação esta inserção é funcional ${ }^{126}$.

Em outras palavras, a coordenação é identificada pela conexão funcional da prestação, dada a sua inserção na organização empresarial relacionada às finalidades perseguidas pelo contratante, legitimado, nesta perspectiva e sempre nos limites dos resultados a serem alcançados, a promover certas ingerências da atividade do prestador mas sem exercitar os poderes típicos da relação de trabalho subordinado ${ }^{127}$.

A coordenação em estudo assume o sentido de "ordenar juntos", de sorte que as duas partes possuem medidas para propor visando alcançar o objetivo comum. Admite-se a possibilidade de alteração do programa contratual conforme seu

\footnotetext{
${ }^{124}$ GARATTONI, Marina. Op. cit., p. 33-35.

125 Ibidem, p. 36.

126 SILVA, Otavio Pinto e. Subordinação, autonomia e parassubordinação nas relações de trabalho. São Paulo: Ltr, 2004, p. 105 e 107.

127 LEONE, Gabriella. Le collaborazioni (coordinate e continuative) a progetto. In Rivista Giuridica del lavoro e della Previdenza Sociale, ano 55, n. 1, janeiro/março 2004, Roma, p. 93.
} 
desenvolvimento ${ }^{128}$.

A coordenação típica do trabalho parassubordinado é individuada pelo fato de a ligação da prestação ao programa desenvolvido pelo tomador ser previamente fixada, através da determinação do modo e do tempo de sua execução ou no fato de sua realização ser delegada, em sua totalidade ou em sua maior parte, à escolha do trabalhador. O requisito em questão subsiste ainda quando o cliente fixe as diretivas ou estabeleça, em linhas gerais, o modo da execução da prestação do colaborador. Por outro lado, a relação deve ser considerada como de subordinação quando o empregador especifica, no curso da obra, o conteúdo da prestação, exigindo em sede contratual apenas a disponibilidade do empregado $^{129}$.

Por continuidade entende-se a prestação de serviço que atende a uma necessidade do tomador prolongada no tempo, considerando os interesses das duas partes. Relaciona-se a uma série de resultados que as partes pretendem atingir, mostrando-se incompatível com a realização de uma única obra, ainda que sua execução exija um certo tempo $^{130}$. Assim, a prestação parassubordinada será continuativa no caso de uma série de adimplementos, em um período determinado de tempo, de modo que a atividade possa ser programada pelo trabalhador em razão de uma exigência não transitória do tomador. Consequentemente, é afastada quando a reiteração da prestação é meramente ocasional, ou seja somente o resultado de um contingência de fato, não prevista e não previsível $^{131}$.

Assim, a continuidade não é entendida em um sentido meramente cronológico, mas interage com o elemento da coordenação, isto é, um intenso grau de coordenação em relação às exigência do tomador constituirá um melhor indício do caráter continuativo da prestação ${ }^{132}$.

Ainda, para a caracterização do trabalho parassubordinado, exige-se a natureza prevalentemente pessoal da prestação de serviços. Trata-se, para a jurisprudência italiana, de um elemento decisivo no sentido de que frequentemente determina o enquadramento de uma relação no âmbito de aplicação do art. 409, n. 3, do

\footnotetext{
${ }^{128}$ SILVA, Otavio Pinto e. Subordinação, autonomia e parassubordinação nas relações de trabalho. São Paulo: Ltr, 2004, p. 106

129 GARATTONI, Marina. Op. cit., p. 37-38.

${ }^{130}$ SILVA, Otavio Pinto. Subordinação, autonomia e parassubordinação nas relações de trabalho. São Paulo: Ltr, 2004, p. 104.

131 GARATTONI, Marina. Op. cit., p. 38-39.

132 Ibidem, p. 39
} 
Código de Processo Civil. É entendido como a prevalência da atividade do prestador de serviços sobre o trabalho desenvolvido por eventuais colaboradores e, também como a prevalência sobre outros fatores necessários à execução da prestação e, em particular, sobre a utilização de uma estrutura de tipo material ${ }^{133}$.

Desta maneira, diante de uma estrutura empresarial organizada ou mesmo diante uma pessoa física que conte com trabalhadores subordinados organizandoos, não há que se falar em trabalho parassubordinado ${ }^{134}$.

Embora sujeito à orientação geral dos serviços, emitida pelo tomador, o trabalhador parassubordinado não está sujeito aos poderes de comando e disciplinar. São citados como exemplos de trabalhadores parassubordinados: prestadores de trabalho associativo (sociedades em conta de participação, membros de cooperativas de trabalho, sócio de indústria, membros de empresa familiar), representantes comerciais, propagandistas, agentes teatrais, cinematográficos e esportivos, corretores de toda espécie de negócios (como os corretores de imóveis), concessionários de vendas, pequenos empresários (dependentes economicamente de indústrias a que prestam colaboração contínua), profissionais liberais (como o advogado que trata de modo contínuo dos interesses de uma pessoa física, o médico da família, etc) ${ }^{135}$. Tais trabalhadores não são subordinados, mas prestam uma colaboração contínua e coordenada à empresa contratando seus serviços com esta em condições de inferioridade sob a modalidade de contratos civis ou mercantis, como de obra, prestação de serviços profissionais, transporte etc ${ }^{136}$.

Se na subordinação é o próprio trabalhador que, pessoalmente, se insere na estrutura empresarial, na parassubordinação é a sua atividade prestada que se insere nos fins da empresa. É utilizada a expressão "colaboração para a empresa" a evidenciar que os

133 GARATTONI, Marina. Op. cit., p. 40.

134 BULGUERONI, Renata Orsi. Trabalho autônomo dependente: experiências italiana e espanhola e a realidade brasileira. Dissertação apresentada à banca examinadora da Faculdade de Direito da Universidade de São Paulo como exigência parcial para obtenção do título de Mestre em Direito do Trabalho e Seguridade Social. São Paulo, 2011, p.46.

135 ROMITA, Arion Sayão. A crise do critério da subordinação jurídica - necessidade de proteção a trabalhadores autônomos e parassubordinados. In Revista de Direito do Trabalho, ano 31, n. 117, janeiro-março de 2005, p. 56. Referido autor entende que, a menos que haja uma reformulação da legislação trabalhista que lhe dê aspectos totalmente diferentes dos atualmente existentes, não há possibilidade de aplicar aos trabalhadores parassubordinados as normas de direito do trabalho. Coloca que a tendência expansionista do direito do trabalho proclamada em meados do século XX não se confirmou. Ao contrário, o direito do trabalho, a partir dos últimos três decênios do século XX, retraiu-se e continua a encolher, sob a irrefreável ofensiva do setor informal( p. 59).

136 BARROS, Alice Monteiro de. Curso de direito do trabalho. $6^{\mathrm{a}}$ ed. São Paulo: Ltr, 2010, p. 289. 
resultados do trabalho desenvolvido estão de acordo com os objetivos do contratante ${ }^{137}$.

Trata-se de uma modalidade de prestação de serviços intermediária entre o trabalho autônomo e o subordinado e sua configuração não implica acesso à disciplina típica do trabalho subordinado ${ }^{138}$. Aliás, cabe notar que, firmou-se na Itália o entendimento de que as regras aplicáveis aos trabalhadores parassubordinados são aquelas destinadas à tutela do trabalhador autônomo clássico. Mas reconhecendo-se a característica da dependência que norteia estas relações de trabalho, o legislador italiano, através de uma lógica seletiva de extensão de tutelas, permitiu a aplicação de alguns direitos característicos do trabalho subordinado aos colaboradores ${ }^{139}$.

Exemplificativamente, cita-se o particular regime previdenciário introduzido pela Lei 335/95 segundo o qual os colaboradores são inscritos em uma gestão separada juntos ao INPS e financiada por contribuições a cargo do comitente (dois terços) e do colaborador (um terço). Também há a previsão de uma tutela assistencial mínima como a tutela por doença em caso de período de internação prevista para particulares condições (Lei 488/1999), como uma cobertura para os casos de acidente e doenças profissionais e como uma tutela em caso de maternidade ${ }^{140}$. Menciona-se, também, uma tutela tributária menos onerosa para as relações de parassubordinação (Lei 343/2000 e decretos presidenciais 597/73 e 917/86) ${ }^{141}$.

Portanto, os traços característicos da prestação de trabalho parassubordinado se expressam na continuidade, na coordenação, na prevalência da

${ }_{137}$ BULGUERONI, Renata Orsi. Trabalho autônomo dependente: experiências italiana e espanhola e a realidade brasileira. Dissertação apresentada à banca examinadora da Faculdade de Direito da Universidade de São Paulo como exigência parcial para obtenção do título de Mestre em Direito do Trabalho e Seguridade Social. São Paulo, 2011, p. 72.

${ }_{138}$ PEDREIRA, Pinho. Um novo critério de aplicação do direito do trabalho: a parassubordinação. In Revista de Direito do Trabalho, ano 27, n. 103, julho-setembro de 2001, p.176. A doutrina e a jurisprudência italianas predominantes não projetam este critério de parassubordinação como substitutivo da subordinação como elemento determinante da aplicação do Direito do Trabalho, mas como um fato próprio de certas categorias de trabalho autônomo que requerem ser tuteladas por serem prevalentemente pessoais, contínuas e coordenadas, em condições que evidenciam uma debilidade contratual por parte de quem presta os serviços. Mas a afirmação de que estas categorias requerem uma tutela legislativa não significa, no sentir majoritário da doutrina italiana, que esta deva ser outorgada nos termos da disciplina jurídica dada aos trabalhadores subordinados ( URIARTE, Oscar Ermida, ALVAREZ, Oscar Hernández. Apuntes sobre los cuestionamientos al concepto de subordinación. In Revista de Direito do Trabalho, $\mathrm{n}$. 103, ano 27, julho-setembro de 2001, Editora Revista dos Tribunais, p. 213).

139 BULGUERONI, Renata Orsi. Parassubordinção: origem, elementos, espécies e tutela. In Revista de Direito de Trabalho, ano 34, n. 131, jul.-set./2008, p. 332.

${ }^{140}$ GALANTINO, Luisa. Op. cit., p. 23.

141 BULGUERONI, Renata Orsi. Parassubordinção: origem, elementos, espécies e tutela. In Revista de Direito de Trabalho, ano 34, n. 131, jul.-set./2008, p. 332. 
pessoalidade e na ausência de subordinação. São, portanto, colaborações coordenadas e continuadas ("co.co.co") ${ }^{142}$. Deve-se esclarecer que essas colaborações continuativas e coordenadas algumas vezes mascaram uma relação de trabalho subordinado, mas em outros casos, são autênticas, ou seja, são formas de trabalho autônomo continuativo ${ }^{143}$.

A ideia da parassubordinação como o reconhecimento de um trabalho situado entre a subordinação e autonomia também é encontrada em outros países europeus, embora em menor extensão e com configuração diversa. Na maioria dos casos, consiste na aplicação reduzida do Direito do Trabalho a trabalhadores considerados juridicamente autônomos, mas economicamente dependentes ${ }^{144}$.

Assim, na Espanha, o Estatuto do Trabalhador Autônomo, promulgado pela Lei 20/2007, incorporou ao ordenamento jurídico espanhol a figura do trabalho parassubordinado através da conceituação do trabalhador autônomo economicamente dependente, a quem é conferido um tratamento particular por se encontrar em uma situação mais próxima àquela ocupada pelo trabalhador assalariado ou por conta alheia ${ }^{145 .}$

Esta nova figura surge em um contexto de revisitação do conceito de subordinação jurídica como elemento de aplicação do Direito do Trabalho. Diante das alterações do mercado de trabalho e da organização empresarial, percebeu-se a necessidade de haver um redimensionamento das categorias destinatárias da tutela trabalhista. $\mathrm{O}$ legislador espanhol fixou um critério preciso e objetivo de trabalhador autônomo economicamente dependente visando afastar incertezas e prevenir a utilização fraudulenta do instituto ${ }^{146}$.

${ }^{142}$ LEVI, Alberto. Op. cit. p. 258. A este respeito, Giuseppe Santoro-Passarelli coloca que a jurisprudência italiana analisa estas relações averiguando a existência de seus elementos característicos: continuidade, coordenação e o caráter prevalentemente pessoal da prestação, ao invés de averiguar a hipossuficiência contratual do prestador de serviço (Diritto dei Lavori. Seconda edizione. Torino: G. Giappichelli Editore, 2004, p. 287). No mesmo sentido, Lorena Vasconcelos Porto coloca que a maioria da doutrina e da jurisprudência italiana considera que a situação de hipossuficiência socioeconômica e contratual é irrelevante para fins qualificatórios da parassubordinação, constituindo, assim como ocorre no trabalho subordinado, apenas o motivo que levou à construção do modelo normativo da respectiva disciplina (Op. cit., p. 120).

143 SANTORO-PASSARELLI, Giuseppe. Globalizzazione e lavoro subordinato. In Roma e America. Diritto Romano Comune, Rivista di Diritto dell'Integrazione e Unificazione del Diritto in Europa e in America Latina, Roma, Itália, n. 15, 2003, p. 228.

144 PORTO, Lorena Vasconcelos. Op. cit., p. 104.

145 GARCÍA, Rosa María Morato. El reconocimento legal de la figura del trabajador autónomo económicamente dependiente em España. In Revista Complejus - AMATRA 21 - Associação dos Magistrados do Trabalho da $21^{a}$ Região, V. 1, N. 1, jan./jun. 2010, p. 48-50. Disponível em http://www.amatra21.org.br/Revista\%5CRevista\%20Complejus.pdf, acesso 23.01.2012.

146 BULGUERONI, Renata Orsi. Trabalho autônomo dependente: experiências italiana e espanhola e a 
Tradicionalmente, na Espanha, os autônomos formavam um grupo social muito numeroso. No ano de 2007, se estimava que este grupo era composto por cerca de três milhões de pessoas, embora nos últimos meses de 2008 e no ano de 2009 tenha ocorrido uma redução diante da crise econômica, da falta de liquidez e da desaceleração da atividade produtiva. Além disso, formam um grupo muito heterogêneo. $\mathrm{O}$ certo é que, nos últimos tempos, em razão da nova conformação do sistema produtivo e das novas formas de competitividade das empresas, o trabalho autônomo tem se desenvolvido em novas atividades econômicas, como atividades industriais e de serviços em que, até então, sua participação era escassa. Por outro lado, houve uma alteração das funções que os autônomos desempenham em atividades das quais tradicionalmente participavam, como comércio, agricultura, artesanato e profissionais liberais ${ }^{147}$.

O Estatuto do Trabalhador Autônomo (Lei 20/2007, de 11 de julho) prevê a figura do trabalhador autônomo clássico e a do trabalhador autônomo economicamente dependente. O primeiro é pessoa física que realiza, de forma habitual, pessoal, direta, por conta própria e fora do âmbito de direção e organização de outra pessoa, uma atividade econômica ou profissional a título lucrativo, dando ou não ocupação a trabalhadores por conta alheia ${ }^{148}$.

Já o trabalhador economicamente dependente corresponde àquele cujo ganho está concentrado em um comitente para o qual exerce a maior parte de sua atividade. Especificamente, trata-se do trabalhador que realiza uma atividade econômica ou profissional lucrativa de forma habitual, pessoal, direta e predominantemente para uma pessoa física ou jurídica da qual aufere pelo menos $75 \%$ de seus ganhos. Não pode ter empregados nem subcontratar serviços, deve ter infraestrutura produtiva e material próprios, assumir os riscos de sua atividade e desenvolver seu trabalho com critérios organizativos próprios $^{149}$.

realidade brasileira. Dissertação apresentada à banca examinadora da Faculdade de Direito da Universidade de São Paulo como exigência parcial para obtenção do título de Mestre em Direito do Trabalho e Seguridade Social. São Paulo, 2011, p. 109 e 111.

147 GARCÍA, Rosa María Morato. Op. cit., p. 49-50.

148 NASCIMENTO, Amauri Mascaro. Curso de direito do trabalho: história e teoria geral do direito do trabalho: relações individuais e coletivas do trabalho. $24^{\mathrm{a}}$ ed. Rev. Atual. E ampl. São Paulo: Saraiva, 2009, p. 841-842.

149 Ibidem, p. 841-842.

A definição desta figura legal encontra-se no artigo 11, item 1 do Capítulo III, do referido Estatuto do Trabalhador Autônomo, nos seguintes termos: Los trabajadores autónomos económicamente dependientes a los que se refiere el artículo 1.2.d) de la presente Ley son aquéllos que realizan una 
Trata-se de trabalhadores que são formalmente donos de seu trabalho, que contam com um negócio próprio, mas que prestam serviços a outras empresas. $\mathrm{O}$ fato singular, para o qual o legislador espanhol decidiu tecer especial atenção, é a concretização de uma relação comercial habitual, de trato sucessivo, com o mesmo cliente. Nestes casos, verifica-se um certo tipo de dependência, a dependência econômica, chegando o trabalhador a perder parte de sua autonomia funcional já que na maioria das vezes deve adaptar-se às instruções gerais que partem da empresa, assim como deve adaptar-se às linhas de produção. O trabalhador economicamente dependente pode receber indicações ou instruções, meramente programáticas ou genéricas, relativas à realização da atividade. Mas tais disposições de caráter técnico não supõem que este trabalhador perca ou renuncie à sua liberdade de decisão em torno da execução da atividade profissional sobre a qual em todo o momento mantém seu controle organizativo. Trata-se de instruções técnicas, reveladoras de uma relação de mera coordenação ${ }^{150}$.

Na Espanha, portanto, ganha destaque o fato de o trabalhador autônomo possuir dependência econômica de uma única (ou principal) empresa cliente. Já na Itália, destaca-se a noção de coordenação entre o tomador e o prestador de serviço. Porém, ambos os ordenamentos visam proteger trabalhadores juridicamente autônomos, que prestam serviços de forma contínua, não eventual, com pessoalidade, com ausência da subordinação jurídica clássica e que dependem quase exclusivamente de um único cliente. Por esta razão, em alguns textos as expressões parassubordinação e trabalho autônomo

actividad económica o profesional a título lucrativo y de forma habitual, personal, directa y predominante para una persona física o jurídica, denominada cliente, del que dependen económicamente por percibir de él, al menos, el 75 por ciento de sus ingresos por rendimientos de trabajo y de actividades económicas o profesionales.

$\mathrm{O}$ artigo 11, item 2 segue dispondo que: 2. Para el desempeño de la actividad económica o profesional como trabajador autónomo económicamente dependiente, éste deberá reunir simultáneamente las siguientes condiciones:

a) No tener a su cargo trabajadores por cuenta ajena ni contratar o subcontratar parte o toda la actividad com terceros, tanto respecto de la actividad contratada con el cliente del que depende económicamente como de las actividades que pudiera contratar con otros clientes.

b) No ejecutar su actividad de manera indiferenciada con los trabajadores que presten servicios bajo cualquier modalidad de contratación laboral por cuenta del cliente.

c) Disponer de infraestructura productiva y material propios, necesarios para el ejercicio de la actividad e independientes de los de su cliente, cuando en dicha actividad sean relevantes económicamente.

d) Desarrollar su actividad con criterios organizativos propios, sin perjuicio de las indicaciones técnicas que pudiese recibir de su cliente.

e) Percibir una contraprestación económica en función del resultado de su actividad, de acuerdo con lo pactado con el cliente y asumiendo riesgo y ventura de aquélla.

150 GARCÍA, Rosa María Morato. Op. cit., p. 51-54. 
economicamente dependente são utilizadas como sinônimas ${ }^{151}$.

Na Alemanha, a divergência entre autônomos, excluídos da proteção da lei trabalhista, e os empregados, inteiramente cobertos por esta legislação, nunca chegou a uma solução satisfatória. Este é o motivo pelo qual uma terceira categoria, denominada de "pessoas semelhantes a empregados" (employee-like person), foi criada para classificar aqueles que, de acordo com a tradicional definição de empregado, nela não se encaixam totalmente por serem autônomos, mas a sua situação econômica se assemelha a de um empregado $^{152}$.

Mais especificamente, o conceito de "pessoa semelhante ao trabalhador subordinado" surge pela primeira vez na legislação alemã em 1926, com a introdução da jurisdição unitária e estatal do trabalho prevista pela lei sobre os tribunais do trabalho (Arbeitsgerichtsgesetz $=$ ArbGG). Assim, os tribunais para as questões do trabalho não são competentes apenas para os trabalhadores subordinados, mas também para as outras categorias que envolvem pessoas semelhantes ao trabalhador subordinado ${ }^{153}$.

Os indivíduos deste grupo são cobertos por algumas regras e princípios do direito do trabalho como as relacionadas à saúde e segurança no ambiente do trabalho, ao acesso ao sistema de tribunais especializado no trabalho e podem ser incluídos nos acordos coletivos $^{154}$.

O critério tradicionalmente utilizado para distingui-los é o da dependência econômica. Esta noção de "pessoas assemelhadas a empregados" foi desenvolvida pela jurisprudência e, embora não tenha delimitações claras, alguns critérios são utilizados para sua identificação: os assemelhados a empregados devem desenvolver, por si próprios, suas tarefas contratuais e, essencialmente, sem a ajuda de empregados; a maior parte de sua atividade deve ser desenvolvida para uma pessoa ou instituição ou, mais da metade de sua renda deve ser paga por uma pessoa ou instituição. Deve ser observado que o termo pessoa ou instituição também envolve grupo empresarial. Em se tratando de

${ }^{151}$ GOULARD, Rodrigo Fortunato. Trabalhador autônomo e contrato de emprego. Curitiba: Juruá, 2012, p. 77.

152 WEISS, Manfred. The evolution of the concept of subordination: the german experience. Aracaju: Evocati Revista n. 21 Disponível em: < http://www.evocati.com.br/evocati/artigos.wsp?tmp_codartigo=150 >. Acesso em: 28/02/2012.

153 KEMPEN, Otto Ernst, KRETZSCHMAR, Robert. Op. cit., p. 266-267.

154 WEISS, Manfred. The evolution of the concept of subordination: the german experience. Aracaju: Evocati Revista n. 21 Disponível em: < http://www.evocati.com.br/evocati/artigos.wsp?tmp_codartigo=150 >. Acesso em: 28/02/2012. 
artistas, escritores e jornalistas há um critério específico, qual seja, que mais de 1/3 de sua renda seja pago por uma pessoa ou instituição ${ }^{155}$.

O trabalhador parassubordinado alemão apresenta semelhanças com a figura do Direito italiano, na medida em que exige o requisito da continuidade e da prevalente pessoalidade. Todavia, enquanto o Direito alemão coloca como critério a dependência econômica, a lei italiana não se refere expressamente a esta ${ }^{156}$.

A preocupação europeia com a figura do trabalhador autônomo evidencia uma tendência ao alargamento do Direito do Trabalho para envolver relações até então excluídas de seu âmbito de aplicação, mesmo considerando que as legislações italiana, espanhola e alemã atribuem ao trabalhador autônomo hipossuficiente uma tutela mais restritiva do que aquela concedida ao empregado. Neste âmbito de proteção, cita-se o reconhecimento dos seguintes direitos: inserção no sistema de seguridade social, direito a constituir ou filiar-se a sindicatos, meio ambiente de trabalho seguro, não discriminação em matéria de trabalho ${ }^{157}$.

O art. 10, do Código do Trabalho de Portugal, cuja aplicação se destina a situações equiparadas, assim dispõe:

Art. 10: "As normas legais respeitantes a direitos de personalidade, igualdade e não discriminação e segurança e saúde no trabalho são aplicáveis a situações em que ocorra prestação de trabalho por uma pessoa a outra, sem subordinação jurídica, sempre que o prestador de trabalho deva considerar-se na dependência econômica do beneficiário da atividade ${ }^{158}$ ".

Como importante síntese, relata-se uma análise de Direito Comparado (legislação e doutrina italiana, alemã e francesa) feita por Adalberto Perulli que extrai uma série de critérios ou indícios de dependência econômica (ou parassubordinação): a) pessoalidade ou prevalente pessoalidade para a execução da obra: a norma italiana (art. 409, n. 3 Cod. Proc. Civ.) exclui do âmbito do trabalho parassubordinado aquelas relações

${ }^{155}$ WEISS, Manfred. The evolution of the concept of subordination: the german experience. Aracaju: Evocati Revista n. 21 Disponível em: $<$ http://www.evocati.com.br/evocati/artigos.wsp?tmp_codartigo $=150>$. Acesso em: 28/02/2012.

${ }_{156}$ PORTO, Lorena Vasconcelos. Op. cit., p. 110.

${ }^{157}$ GOULARD, Rodrigo Fortunato. Op. cit., p. 77-81.

${ }^{158}$ Código do Trabalho de Portugal, aprovado pela Lei 7/2009. Disponível em http://www.legix.pt/Portals/3/docs/CT09-23_Jul 2012.pdf . Acesso 12.08.2013. 
em que a atividade de colaboração assume um verdadeiro caráter empresarial, como ocorre com uma atividade desenvolvida com forma societária, mediante ampla e articulada organização; b) ausência de um contato direto com o mercado: uma parte significativa dos trabalhadores economicamente dependentes prestam a sua atividade em favor de seus clientes, se preocupando, de forma secundária, em colocar os produtos no mercado (esta ausência de uma real ligação com o mercado representa, para uma certa parte da doutrina alemã, o principal indicador da dependência econômica); c) exclusividade ou quase exclusividade da relação contratual da qual o trabalhador extrai seus rendimentos mensais ou anuais: coloca o autor que, no sistema italiano, este critério da destinação exclusiva da atividade a um só cliente, ainda que não esteja expressamente previsto no art. 409, n. 3, do Cod. Proc. Civ., pode ser depreendido dos requisitos tipificados na norma, sendo que a jurisprudência que, em muitas vezes, identifica a continuidade com exclusividade, considera razoável a utilização deste indicador praeter legem, principalmente nos casos em que os outros requisitos da parassubordinação não estejam tão claros; já no sistema alemão, esta relação restrita representa a dimensão particular do trabalho parassubordinado; no sistema francês, assume relevo medir o grau de dependência econômica, a quantidade de renda percebida em base do contrato; d) inserção funcional da prestação no ciclo da empresa: este elemento não é entendido como a inserção do trabalhador na organização empresarial, característica do trabalho subordinado, mas no sentido da ligação funcional da prestação a um determinado contexto ou ciclo produtivo; e) ausência de diretivas do credor, mas presença de um poder de coordenação das prestações: considerando que o trabalhador economicamente dependente permanece tipologicamente ancorado ao trabalho autônomo, a coordenação da prestação não interfere com a autonomia organizativa da atividade laborativa, mas relaciona-se à ligação funcional desta com a atividade do credor; se no plano funcional a colaboração parassubordinada pode concorrer de fato a realizar módulos organizativos de quase hierarquia, no plano estrutural esta não implica o estreito laço existente na relação de subordinação; f) duração da relação: Este elemento de duração constitui um elemento elástico e frequentemente valorizado por juristas alemães e italianos; a jurisprudência italiana considera essencial o elemento da duração enquanto a atividade do prestador de serviço corresponda à exigência 
de satisfazer uma necessidade estável do contratante ${ }^{159}$.

$\mathrm{Na}$ realidade, o surgimento e desenvolvimento da doutrina da parassubordinação ocorrem em razão da dificuldade de formalização jurídica de diversos tipos de trabalho que se desenvolveram com o pós fordismo e em razão da crítica dirigida ao ramo justrabalhista de se mostrar incapaz de abarcar estas novas realidades e de proteger todo e qualquer trabalho de acordo com seu critério teleológico ${ }^{160}$.

Críticas são feitas à parassubordinação. Aqueles que se opõem ao seu reconhecimento argumentam que qualificar um trabalhador como parassubordinado consiste em adotar um conceito restrito de subordinação, diminuindo o campo de proteção do Direito do Trabalho, viabilizando uma forma disfarçada de desemprego, além de proporcionar uma fuga ao Direito do Trabalho ${ }^{161}$. Trata-se de uma forma que evita que este ramo do Direito atinja por completo os novos modos que o capital encontra para explorar o trabalho. Admitir que o Direito do Trabalho se adapte à nova realidade acarretando uma regressão de direitos significa negar sua raiz ligada ao Direito Social e negar sua função de impor limites ao poder econômico e promover justiça social, que é fundamento da garantia da paz mundial. A ideia central da incidência do Direito do Trabalho deve ser o trabalho sob dependência alheia ${ }^{162}$.

Jorge Luiz Souto Maior coloca que nenhuma alteração substancial ocorreu no mundo do trabalho capaz de justificar a utilização da expressão "novos paradigmas" ou de justificar o fim do emprego, que existirá enquanto o sistema capitalista perdurar. As mudanças operadas no sistema de produção se alimentam da mesma lógica de exploração da força de trabalho anteriormente existente, o que justifica a manutenção do Direito do Trabalho, na forma como concebido. Assim, para referido autor, a qualificação do trabalhador como "colaborador", "parassubordinado" faz crer que nas relações de trabalho atuais não existe a exploração da força de trabalho. Na realidade, esta exploração continua existindo de maneira mais sofistica e é nesta exploração que o Direito do

${ }^{159}$ Lavoro Autonomo e dipendenza economica, oggi. In Rivista Giuridica del lavoro e della Previdenza Sociale, anno LIV, 2003, n. 2, aprile/giugno 2003, p. 229-238.

${ }^{160}$ DELGADO, Gabriela Neves. Direito fundamental ao trabalho digno. São Paulo: Ltr, 2006, p. 192.

${ }^{161}$ VIANA, Márcio Túlio. Trabalhadores Parassubordinados: Deslizando para fora do Direito. In RENAULT, Luiz Otávio Linhares [et al]. Parassubordinação: em homenagem ao Professor Márcio Túlio Viana. São Paulo: Ltr, 2011, pp. 30-32. PORTO, Lorena Vasconcelos. Op. cit., p.102.

${ }^{162}$ MAIOR, Jorge Luiz Souto, A Supersubordinação. In Renault, Luiz Otávio Linhares [et al]. Parassubordinação: em homenagem ao Professor Márcio Túlio Viana. São Paulo: Ltr, 2011, p. 60-61. 
Trabalho encontra a lógica de sua existência ${ }^{163}$.

Porém, a teoria da parassubordinação não visa ser um óbice à caracterização da relação de emprego, tampouco uma forma de fraudá-la. A relação de emprego sempre existirá nos diversos ramos da economia e seu reconhecimento é imperioso principalmente nos casos de fraude. A teoria da parassubordinação surge em um contexto de alteração do mundo do trabalho, em que se estimula a formação de vínculos autônomos, ainda que estas transformações atinjam um pequeno número de trabalhadores.

Em outras palavras, a parassubordinação nasce para alcançar trabalhadores que se encontram em uma zona cinzenta ("zona grise"), em que a relação de trabalho do prestador de serviços apresenta elementos não muito bem traçados, obscuros, que fazem com que o aplicado do Direito tenha dúvidas no tocante ao enquadramento da relação jurídica, como relação de emprego ou relação de trabalho autônomo. A noção de parassubordinção foi criada para relações de trabalho que se inserem na organização da empresa, embora se desenvolvam com independência e sem a direção do tomador de serviços. Além disso, a divisão do trabalho autônomo e trabalho subordinado permitiu uma proteção de quem não precisava ser protegido com a mesma intensidade, como os altos empregados e deixou de proteger quem deveria, como alguns autônomos em situação de debilidade contratual ou dependência econômica ${ }^{164}$. Trata-se de um modelo intermediário que se destina, especialmente, aos trabalhadores intelectuais ${ }^{165}$.

Importante notar que a instituição do trabalho parassubordinado ao lado do trabalho autônomo e do trabalho subordinado implica em um redimensionamento do Direito do Trabalho a exigir a definição de sua tutela jurídica ${ }^{166}$. Há a necessidade de um estatuto de proteção não apenas voltado ao empregado, mas também voltado a outros trabalhadores, já que a omissão do Direito do Trabalho contribui para o aumento da crise hoje vivenciada marcada pela informalidade e pela indevida utilização de certas construções jurídicas ${ }^{167}$.

\footnotetext{
163 Relação de emprego e direito do trabalho: no contexto da ampliação da competência da justiça do trabalho. São Paulo: Ltr, 2007, p. 14-43.

164 BARROS, Juliana Augusta Medeiros de. O Trabalho Parassubordinado e o art. $7^{\circ}$, caput, da Constituição Federal de 1998. In RENAULT, Luiz Otávio Linhares [et al]. Parassubordinação: em homenagem ao Professor Márcio Túlio Viana. São Paulo: Ltr, 2011, p. 133-134 e 140.

165 PEREIRA, Leone. Op cit., p. 59.

166 BARROS, Alice Monteiro de. Curso de Direito do Trabalho. 6 ed., São Paulo: Ltr, 2010, p. 291-292.

167 MANNRICH, Nelson. Distinções entre relação de emprego e contratos de prestação de serviços. Contratos atípicos no Direito Brasileiro e no Direito Comparado. In ANAN JUNIOR, Pedro, PEIXOTO,
} 
Em outras palavras, impõe-se uma nova visão das relações de trabalho a partir da valorização do trabalho autônomo e do desenvolvimento do trabalho parassubordinado, que devem ser concebidos como mecanismos alternativos de prestação de serviços, como novos instrumentos que visem garantir a todos os cidadãos o acesso ao trabalho decente, inserido em um política de promoção dos direitos humanos fundamentais ${ }^{168}$.

No Brasil, não obstante a ausência de legislação a respeito, é possível encontrar jurisprudência que reconhece este instituto, embora em alguns casos a parassubordinação seja mais relacionada ao trabalho autônomo, afastando a concessão de quaisquer direitos trabalhistas e, em outros, seja defendida sua aproximação ao trabalho subordinado.

Ilustrativamente, a primeira situação pode ser aferida no julgamento realizado pela $5^{\text {a }}$ Turma, do Tribunal Regional do Trabalho da $2^{\text {a }}$ Região (processo 0002104-73.2011.5.02.0203), em que a parassubordinação foi definida como "o estado de sujeição do trabalhador que não é empregado, podendo ser autônomo, eventual ou de qualquer outra espécie" . No caso dos autos, foi reconhecida a existência de uma relação de coordenação dos serviços prestados sendo que o fato de o tomador dos serviços estipular balizas para a realização do que fora contratado não implica em subordinação jurídica. Reconheceu-se o caráter autônomo da prestação de serviços, afastando-se a configuração da relação de emprego ante a ausência da pessoalidade, subordinação e não assunção de riscos (TRT 2, $5^{\mathrm{a}}$ Turma, Processo 0002104-73.2011.5.02.0203, Juiz relator: Donizete Vieira da Silva, Acórdão 20130074157) $)^{169}$

Em outro julgado do Tribunal Regional do Trabalho da $2^{\mathrm{a}}$ Região, reconheceu-se que, na parassubordinação, inerente aos contratos de representação comercial, o contratante exerce um poder de direção ao contratado ínsito às vicissitudes da atividade empreendida, diante da necessidade de cumprimento de metas. No caso, a reclamante efetuava venda de produtos de beleza da linha infantil. $\mathrm{O}$ fato de encaminhar relatórios de vendas, de participar de reuniões mensais e, eventualmente, de contar com o

Marcelo Magalhães (coordenadores). Prestação de serviços intelectuais por pessoas jurídicas: aspectos legais, econômicos, tributários. São Paulo: MP Ed, 2008 , p. 167.

168 SILVA, Otavio Pinto e. A função do Direito do Trabalho no mundo atual. In CORREIA, Marcus Orione Gonçalves (organizador). Curso de Direito do Trabalho - Teoria Geral do Direito do Trabalho. Volume I. Ltr, 2007-2008., p. 145.

169 Disponível em http://www.trt2.jus.br/pesquisa-jurisprudencia-por-palavra-acordaos, acesso 13.09.2013. 
acompanhamento de supervisores em grandes vendas não foi entendido como elemento de subordinação, mas de parassubordinação, afastando-se a configuração da relação de emprego. A remuneração era exclusivamente por comissão, o que impunha à reclamante a assunção de riscos. Além disso, não havia número mínimo de visitas a serem feitas durante o dia ou na semana (TRT 2, $8^{\mathrm{a}}$ Turma, Processo 00412.2010.382.02.00-4, Juiz relator: Celso Ricardo Peel Furtado de Oliveira, Acórdão 20111229809). ${ }^{170 .}$

Posicionamento diverso é encontrado no julgamento do processo 005462007-091-03-00-0 pelo Tribunal Regional do Trabalho da $3^{\text {a }}$ Região. Entendeu-se que a preposição "para" significa "na direção de", "com destino a", razão pela qual a parassubordinação implica em um tipo de trabalho que se dirige à subordinação e não à autonomia, caso contrário dever-se-ia utilizar a expressão "para - autônomo". A legislação trabalhista brasileira não prevê a parassubordinação, assim, sua admissão deve ser feita mediante uma inteligência inclusiva, com a valorização do trabalho do homem em uma sociedade em mudanças e em fase de assimilação de valores neoliberais. Isto significa que o acolhimento da figura do trabalhador parassubordinado deve ser feito na direção do trabalhador subordinado, com todas as vantagens previstas na CLT e não no sentido de sua identificação com a figura do trabalhador autônomo. Conclui referido julgado que a parassubordinação deve ocorrer dentro e não além do modelo fixado no art. $3^{\circ}$, da CLT (TRT da 3. ' Região; Processo: 0054600-39.2007.5.03.0091 RO; Data de Publicação: 23/02/2008; Órgão Julgador: Quarta Turma; Relator: Luiz Otavio Linhares Renault; Revisor: Convocada Maria Cristina Diniz Caixeta; Divulgação: DJMG . Página 16) ${ }^{171}$

Depreende-se que os magistrados encontram dificuldades para caracterizar estas formas intermediárias de trabalho. Algumas vezes, em razão da ausência de legislação específica voltada a esta realidade, aplicam a legislação trabalhista de maneira intuitiva, casuística, gerando instabilidade e insegurança no sistema das relações de trabalho. Os empregados apresentam cada vez mais uma maior independência técnica e os autônomos se mostram cada vez mais economicamente dependentes ${ }^{172}$.

A perda da centralidade do trabalho subordinado faz surgir a necessidade

170 Disponível em http://www.trt2.jus.br/pesquisa-jurisprudencia-por-palavra-acordaos, acesso 13.09.2013.

171 Disponível em $\underline{\text { http://as1.trt3.jus.br/consulta/redireciona.htm? }}$ pIdAcordao $=578693 \&$ acesso $=\mathrm{d} 88 \mathrm{e} 7 \mathrm{a} 6 \mathrm{a} 2 \mathrm{bfa} 2 \mathrm{~d} 1 \mathrm{cb} 077 \mathrm{da} 0550 \mathrm{bfad} 27$. Acesso dia 29.10.2013.

172 ROBORTELLA, Luiz Carlos Amorim. A reconstrução do conceito de subordinação. In MANNRICH, Nelson [et al.]. Atualidades do direito do trabalho: Anais da Academia Nacional de Direito do Trabalho. São Paulo: Ltr, 2012, p. 277. 
de mecanismos normativos destinados incorporar novas modalidades de trabalho ${ }^{173}$. Enquanto o ordenamento jurídico brasileiro não contiver previsão legal sobre a parassubordinação, será comum encontrar resistência a esta figura e posicionamentos jurisprudenciais divergentes. Adequada seria uma adaptação das experiências estrangeiras à nossa realidade, considerando as peculiaridades que marcam o nosso sistema, como a desigualdade social e a dificuldade de o trabalhador se inserir no mercado de trabalho ${ }^{174}$. Conforme será desenvolvido a seguir, a concessão, às formas de trabalho parassubordinado e autônomo, de direitos trabalhistas considerados mínimos e essenciais seria uma forma adequada de realização dos princípios fundamentais do Direito do Trabalho: valorização do trabalho humano, respeito à dignidade da pessoa humana, realização de justiça social.

\subsection{Do Trabalho Digno.}

Do exposto acima, verifica-se que, em razão da descentralização produtiva, novos padrões de vinculação do trabalho humano passaram a competir com a relação de emprego tradicional, neste início de século XXI. O trabalho autônomo ganha destaque, passando a ser a segunda forma mais importante de ocupação em nossa sociedade, em razão da valorização da especialidade, flexibilidade, descontinuidade e da autonomia. No entanto, tais trabalhadores estão excluídos da proteção do Estado. ${ }^{175}$

Não há, no ordenamento jurídico, uma regulação sobre o trabalho autônomo, no que diz respeito a direitos que eventualmente podem ser estendidos a estes trabalhadores ${ }^{176}$.

A Constituição Federal, em seu Capítulo II, do Título II dispõe sobre os direitos sociais, direitos fundamentais do homem que consistem em prestações positivas realizadas pelo Estado, de maneira direta ou indireta, visando proporcionar melhores

${ }^{173}$ PROSCURCIN, Pedro. O trabalho na reestruturação produtiva - análise jurídica dos impactos no posto de trabalho. São Paulo: Ltr, 2001, p. 143.

174 BULGUERONI, Renata Orsi. Trabalho autônomo dependente: experiências italiana e espanhola e a realidade brasileira. Dissertação apresentada à banca examinadora da Faculdade de Direito da Universidade de São Paulo como exigência parcial para obtenção do título de Mestre em Direito do Trabalho e Seguridade Social. São Paulo, 2011, p. 215.

${ }^{175}$ GOULARD, Rodrigo Fortunato. Op. cit., p. 171-173 e 182.

176 GONÇALVES, Leandro Krebs. Os direitos constitucionais do trabalhador autônomo. Texto publicado no Caderno 14, da Anamatra IV, disponível no site http:/www.amatra4.org.br/cadernos/264-caderno-14?

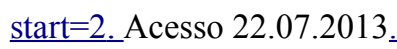


condições de vida aos hipossuficientes. Previstos nas normas constitucionais, são direitos relacionados ao direito de igualdade, pois tendem a igualizar situações socialmente desiguais. Considerando o disposto nos artigos $6^{\circ}$ a 11, da Constituição Federal, podem ser agrupados da seguinte maneira: a) direitos sociais relativos ao trabalhador; b) direitos sociais relativos à seguridade (compreende direito à saúde, à previdência e à assistência social); c) direitos sociais relativos à educação e à cultura; d) direitos sociais relativos à família, à criança, ao adolescente e ao idoso; e) direitos sociais relativos ao meio ambiente 177 .

$\mathrm{O}$ art. $7^{\circ}$, da Carta Magna enuncia os direitos dos trabalhadores em suas relações individuais de trabalho ${ }^{178}$. O caput do referido artigo apresenta a seguinte redação:

Art. $7^{\circ}$ : São direitos dos trabalhadores urbanos e rurais, além de outros que visem à melhoria de sua condição social: (...).

Para Alexandre de Morais, ante a ausência de uma definição sobre o termo "trabalhador", os destinatários dos direitos sociais constitucionalmente previstos neste artigo correspondem aos trabalhadores subordinados, ou seja, aqueles que possuem vínculos de emprego, nos termos previstos pela legislação infraconstitucional ${ }^{179}$.

Para Jorge Luiz Souto Maior, os direitos trabalhistas enunciados no art. $7^{\circ}$, da CF não se referem a todos os trabalhadores. Na medida em que o inciso I, do referido artigo menciona a relação de emprego como direito fundamental, esta relação é que se mostra como sendo a base existencial de todos os demais direitos ali descritos ${ }^{180}$.

Maurício Godinho Delgado coloca que o emprego, regulado por normas jurídicas, é a principal forma de inserção do trabalhador na área sócio econômica capitalista, propiciando-lhe afirmação individual, familiar, social, econômica e ética. Desta maneira, o princípio constitucional da valorização do trabalho deve ser interpretado como sendo a valorização do trabalho regulado, que se confunde com o emprego ${ }^{181}$.

177 SILVA, José Afonso da. Curso de Direito Constitucional Positivo. $16^{\mathrm{a}}$ edição, São Paulo: Malheiros Editores, 1999, p. 289-290.

${ }^{178}$ Ibidem, p. 291.

179 MORAIS, Alexandre de. Direito Constitucional. 15 ed. São Paulo: Atlas, 2004, p. 203.

180 Relação de emprego e direito do trabalho: no contexto da ampliação da competência da Justiça do Trabalho. São Paulo: Ltr, 2007, p. 104.

181 DELGADO, Mauricio Godinho. Direitos fundamentais na relação de trabalho. In Revista Ltr, vol 70, ${ }^{\circ}$ 06, junho de 2006, p. 659-660. 
$\mathrm{O}$ art. 442, caput, da CLT, dispõe que o contrato individual de trabalho é o acordo tácito ou expresso correspondente à relação de emprego. Entendimento consolidado na doutrina é o de que as normas trabalhistas se aplicam ao contrato de trabalho subordinado e não a qualquer relação de trabalho ${ }^{182}$.

Entretanto, apesar deste ramo do Direito ter sua aplicação demarcada às relações de emprego e ao trabalho avulso, não significa que esteja isento de novas investigações e de novas reinterpretações ${ }^{183}$.

Os valores sociais do trabalho, da livre iniciativa e a dignidade da pessoa humana são fundamentos do Estado Democrático de Direito brasileiro (art. $1^{\circ}$, incisos III e IV, da CF). A ordem econômica é fundada na valorização do trabalho humano e na livre iniciativa, com a finalidade de assegurar a todos existência digna, conforme os ditames da justiça social (art. 170, caput, CF) e a ordem social também tem como base o primado do trabalho e, como objetivo, o bem estar e a justiça social (art. 193, CF).

Percebe-se que o princípio da dignidade da pessoa humana representa valor unificador de todos os direitos fundamentais, atuando como referência para aplicação e interpretação das normas constitucionais e infraconstitucionais, principalmente as trabalhistas ${ }^{184}$. Trata-se de qualidade intrínseca de todo o ser humano, irrenunciável e inalienável, que é violada quando o indivíduo é utilizado como instrumento de alcance de finalidades egoísticas de outrem ${ }^{185}$. Embora reconheça tratar-se de um conceito vago e impreciso, Ingo Wolfgang Sarlet define a dignidade da pessoa humana como " a qualidade intrínseca e distintiva reconhecida em cada ser humano que o faz merecedor do mesmo respeito e consideração por parte do Estado e da comunidade, implicando, neste sentido, um complexo de direitos e deveres fundamentais que assegurem a pessoa tanto contra todo e qualquer ato de cunho degradante e desumano, como venham a lhe garantir as condições existenciais mínimas para uma vida saudável, além de propiciar a promover sua participação ativa e corresponsável nos destinos da própria existência e da vida em comunhão com os demais seres humanos ${ }^{186 ", .}$

182 BARROS, Alice Monteiro de. Curso de Direito do Trabalho. 6a ed., São Paulo: Ltr, 2010, p. 221. NASCIMENTO, Amauri Mascaro, Iniciação ao direito do trabalho. 26a ed.. São Paulo: Ltr, 2000, p. 120.

183 DELGADO, Gabriela Neves. Direito fundamental ao trabalho digno. São Paulo: Ltr, 2006, p. 208.

184 GOMES, Dinaura Godinho Pimentel. Direito do trabalho e dignidade da pessoa humana, no contexto da globalização econômica: problemas e perspectivas. São Paulo: Ltr, 2005, p. 32.

185 SARLET, Ingo Wolfgang. As dimensões da dignidade: construindo uma compreensão jurídicoconstitucional necessária e possivel. In SARLET, Ingo Wolfgang, ALEIXO, Pedro Scherer de Melo, ZANINI, Rita Dostal (organizadores). Dimensões da dignidade: ensaios de Filosofia do Direito e Direito constitucional. Porto Alegre: Livraria do Advogado Editora, 2005, p. 19 e 36

186 Op. cit., p. 37. 
Este princípio, portanto, traz a pessoa humana como valor central das sociedades, do Direito e dos Estados contemporâneos, independentemente de seu status econômico, social ou intelectual ${ }^{187}$ e impede que o ser humano seja tratado como mero objeto, principalmente na condição de trabalhador, pois é por meio do trabalho que o homem tem a possibilidade de desenvolver sua personalidade e de obter sua valorização como pessoa. Desta maneira, quando o trabalhador é colocado à margem do sistema, desprovido de proteção legal e perdendo seus referenciais básicos perante seus pares na sociedade, se transforma em mero objeto da atividade econômica ${ }^{188}$.

Jorge Luiz Souto Maior destaca a natureza social do Direito do Trabalho e a centralidade do ser humano como formas de contenção do capitalismo, de produção de justiça social e de preservação da dignidade humana. Enfatiza ser seu princípio fundamental a busca pela melhoria progressiva da condição social e humana do trabalhador, que não se restringe a uma melhoria da condição econômica, mas da melhoria da sociedade como um todo, favorecida pelas ações solidárias ${ }^{189}$.

Uma forma de propiciar ao homem a realização de sua dignidade, no âmbito trabalhista, é o reconhecimento do trabalho decente, entendido como um conjunto mínimo de direitos do trabalhador correspondente à existência de trabalho, à liberdade de trabalho, ao trabalho em condições justas, incluindo remuneração, ao trabalho que preserve a saúde e segurança do trabalhador, à proibição do trabalho infantil, à liberdade sindical e à proteção contra os riscos sociais ${ }^{190}$.

Para a OIT, o conceito de trabalho decente decorre de quatro objetivos estratégicos: o respeito aos direitos no trabalho, a promoção do emprego produtivo e de qualidade, a extensão da proteção social e o fortalecimento do diálogo social. A Declaração da OIT sobre os princípios e direitos fundamentais no trabalho ${ }^{191}$, de 1998 , define como fundamentais quatro princípios que devem ser observados por todos os Membros, quais

187 DELGADO, Mauricio Godinho. Direitos fundamentais na relação de trabalho. In Revista Ltr, vol 70, $\mathrm{n}^{\circ}$ 06, junho de 2006, p. 7.

188 GOMES, Dinaura Godinho Pimentel. Op. cit., p. 28 e 138.

189 Curso de direito do trabalho: teoria geral do direito do trabalho. Volume I. Parte I. São Paulo: Ltr, 2011, p. 618-623.

190 FILHO, José Claudio Monteiro de Brito. Trabalho decente: análise jurídica da exploração, trabalho forçado e outras formas de trabalho indigno. São Paulo: Ltr, 2004, p. 61. GOSDAL, Thereza Cristina. Dignidade do trabalhador: um conceito construído sob o paradigma do trabalho decente e da honra. São Paulo: Ltr, 2007, p. 129.

191 Disponível em http://www.oitbrasil.org.br/sites/default/files/topic/oit/doc/declaracao oit 547.pdf . Acesso 21.11.2013. 
sejam: liberdade sindical e o reconhecimento efetivo do direito de negociação coletiva, a eliminação de todas as formas de trabalho forçado ou obrigatório, a abolição efetiva do trabalho infantil e a eliminação da discriminação em matéria de emprego e ocupação ${ }^{192}$. Com esta Declaração, procurou-se demonstrar que os direitos contidos nos documentos normativos internacionais são direitos humanos $\mathrm{e}$ integram os direitos sociais fundamentais, sendo que os países membros assumem o compromisso de respeitá-los na carta de adesão à OIT (ainda que não tenham ratificado as convenções respectivas) ${ }^{193}$.

Tem-se que, através do trabalho decente, pretende a OIT promover uma globalização justa e capaz de favorecer a inclusão social, coordenando a economia e os valores humanos ${ }^{194}$.

Jean Boissonnat entende que, para ter eficácia e autoridade, o Direito do Trabalho deve preencher três condições: a) as representações feitas do trabalho e da organização da produção devem estar sintonizadas com a realidade e com a evolução dos fatores técnicos, econômicos e sociais; b) seus objetivos devem ser reconhecidos pela sociedade como expressão do interesse geral e devem visar um equilíbrio entre os interesses específicos das diferentes partes envolvidas; c) seus conteúdos devem ser caracterizados pela simplicidade, clareza, estabilidade relativa e coerência. No entanto, coloca que, diante das alterações vivenciadas na sociedade e no modo de produção, este ramo do Direito não atende mais verdadeiramente a nenhuma das três condições, o que impõe uma reforma ${ }^{195}$.

${ }^{192}$ O que é trabalho decente. Disponível em http://www.oitbrasil.org.br/content/o-que-e-trabalho-decente . Acesso 21.11.2013.

${ }^{193}$ PROSCURCIN, Pedro. Do contrato de trabalho ao contrato de atividade: nova forma de regulação das atividades no mercado de trabalho. São Paulo: Ltr, 2003, p. 248. O autor coloca que a elaboração desta Declaração foi motivada pelos retrocessos em matéria social protetiva observados à época, já que entre 1985 a 1997 as normas sociais da OIT nunca foram tão descumpridas.

Luiz Fernando Plens de Quevedo esclarece que os princípios a que se refere a Declaração de 1998 estão contidos em 08 Convenções Fundamentais: a) Convenção no 29 sobre o trabalho forçado, de 1939; b) Convenção $\mathrm{n}^{\mathrm{o}} 87$ sobre a liberdade sindical e proteção do direito de sindicalização, de 1948; c) Convenção $n^{\circ} 98$ sobre o direito de sindicalização e negociação coletiva, de 1948; d) Convenção $n^{\circ} 100$, sobre a igualdade de remuneração, de 1951; e) Convenção $\mathrm{n}^{\circ} 105$, sobre a abolição do trabalho forçado, de 1957; f) Convenção no 111 sobre discriminação no emprego e ocupação, de 1958; g) Convenção no 138 sobre a idade mínima de admissão no emprego, de 1973; h) Convenção n ${ }^{\circ} 182$ sobre as piores formas de trabalho das crianças, de 1999 ( Trabalho como valor e a perspectiva de promoção do trabalho decente sob a ótica da OIT. Dissertação apresentada à Faculdade de Direito da Universidade de São Paulo, Departamento de Direito do Trabalho, como requisito para a obtenção do Título de Mestre. Orientador: Professor Nelson Mannrich. São Paulo, março de 2008, p. 166).

${ }^{194}$ QUEVEDO, Luiz Fernando Plens de. Op. cit., p. 160-167.

1952015 - Horizontes do trabalho e do emprego. Relatório da Comissão presidida por Jean Boissonnat: traduzido por Edilson Alkimim Cunha. São Paulo: Ltr, 1998, p. 237. 
Em face dos princípios acima descritos e da finalidade do Direito do Trabalho, propõe-se uma releitura deste ramo jurídico para que as normas trabalhistas alcancem, notadamente, as relações de trabalho parassubordinado, em que se evidencia uma certa dependência do trabalhador ao tomador de serviços. Mas esta releitura atinge patamares mais altos, pois conforme fundamenta parte da doutrina, com a qual manifestase concordância, a proteção jurídica, ainda que de forma graduada, deve alcançar todas as formas de trabalho, inclusive autônomas.

Alain Supiot expõe que a extensão do campo de aplicação do Direito do Trabalho às formas de contratação autônomas evitará uma divisão entre cidadãos amparados por um contrato de trabalho e cidadãos submetidos a outros tipos contratuais com uma proteção inferior. Uma das funções históricas deste ramo do Direito é estabelecer as bases de coesão social, que deixará de ser possível caso não se adapte à evolução dos modelos de organização do trabalho da sociedade atual. Surge a perspectiva de existência de um Direito do Trabalho comum, o que não obsta que alguns de seus enfoques se adaptem às diversas situações (trabalho subordinado tradicional, trabalho quase subordinado ou economicamente dependente, etc) ${ }^{196}$.

Referido autor entende que a atual condição jurídica de trabalho assalariado deveria ceder espaço ao "estado profissional da pessoa", baseado em uma concepção global do trabalho. É necessário entender as diferentes formas de trabalho mais à luz dos elementos que as unem do que dos elementos que as separam. Somente assim será possível definir um "estado profissional da pessoa" que concilie diversidade com a continuidade da vida laboral ${ }^{197}$.

Jean Boissonnat propõe a criação de um contrato de atividade. Dentre os objetivos a serem perseguidos, apontam-se a necessidade de considerar as evoluções sociais, técnicas e econômicas em curso para atualizar e ampliar o quadro de organização da relação de emprego, que, atualmente, é o contrato de trabalho e conferir ao sistema produtivo as capacidades de adaptação às evoluções da demanda, sejam qualitativas ou quantitativas. Trata-se de mecanismos de flexibilidade e de reversibilidade em termos de especialização, de opção de organização, de alocação de recursos, de competências.

\footnotetext{
196 Transformaciones del trabajo y porvenir del derecho laboral en Europa. In Revista Internacional del trabalho, vol. 118, no 1, Ginebra, 1999, p. 39.

${ }^{197}$ SUPIOT, Alain. Op. cit., p. 40
} 
Defende a integração do trabalho autônomo ao contrato de atividade, aproximando seu regime ao do trabalho assalariado. Com isto, busca-se afastar algumas consequências negativas da "dessalarização" de algumas categorias profissionais e facilitar a mobilidade profissional dos trabalhadores, eliminando efeitos decorrentes da desigualdade entre os regimes, que é cada vez mais difícil de ser justificada diante da evolução das organizações $\operatorname{produtivas}^{198}$.

Propõe que a aproximação dos regimes pode ser feita de algumas maneiras como: pelo acesso à formação profissional contínua; pela unificação do regime de proteção social concedido aos autônomos e assalariados ou, caso não seja possível, pela harmonização dos dois regimes com a suspensão dos obstáculos à passagem de um para outro; pelo desenvolvimento da responsabilidade social dos contratantes e mestres de obra em relação aos trabalhadores autônomos que trabalham por conta própria ou em casa. ${ }^{199}$

Para Pedro Proscurcin, um novo paradigma regulatório deverá alcançar todas as formas de trabalho socialmente úteis, a fim de promover coesão e sentido inclusivo ao mercado laboral. Ao mesmo tempo, deverá permitir que os agentes econômicos mantenham a competitividade no mundo globalizado. Propõe, assim, um novo contrato de trabalho, denominado contrato relacional de atividade e trabalho, cujo objeto é o estado profissional dos trabalhadores, que abrange grande multiplicidade de situações pessoais. Seu escopo é regular as relações de trabalho ou de emprego, o trabalho atípico, a intermitência entre atividades, a formação profissional, a transição de estados profissionais ou atividades independentes, as diversas formas de mutação profissional derivadas de novas técnicas, tecnologia e gerenciamento da produção ${ }^{200}$.

Isto porque a observância do princípio da dignidade humana faz com que sejam tuteladas as atividades independentes, informais e aquelas de transição, não podendo ser remetidas ao Direito Civil. Referido autor entende que o Direito do Trabalho deve abranger as atividades humanas relacionadas direta ou indiretamente à produção de bens ou serviços úteis, pois cabe a ele a regulação, coesão e estabilização do mercado de trabalho. A formulação do contrato de atividade visa a inclusão de todos os trabalhadores que queiram se inserir na vida ativa e se dedicar ao trabalho socialmente útil. Assim,

198 BOISSONNAT, Jean. Op. cit., p. 238-241 e 253-254.

199 Ibidem, p. 253.

200 Do contrato de trabalho ao contrato de atividade: nova forma de regulação das atividades no mercado de trabalho. São Paulo: Ltr, 2003, p. 294 e 334-337. 
abrange os trabalhadores autônomos, informais, voluntário, que hoje são ignorados pelo sistema $^{201}$.

Conclui que o Direito do Trabalho está mergulhado em um ambiente caracterizado pela solidariedade, pela responsabilidade social e pelo respeito à dignidade da pessoa humana, o que impõe a tutela de todas as formas de trabalho úteis ao mercado de trabalho ${ }^{202}$.

Otavio Pinto e Silva defende que chegou o momento de o Direito do Trabalho se adaptar ao mundo atual, de sorte que a negação da diversidade do sistema produtivo para abranger todos os tipos de trabalho no mesmo modelo, qual seja, a relação de emprego, é uma postura falsamente garantidora já que não atende às diversas necessidades dos trabalhadores. Esta adaptação envolve uma revalorização do trabalho autônomo e o desenvolvimento de novas formas contratuais que considerem o trabalho parassubordinado ${ }^{203}$.

Dinaura Godinho Gomes Pimentel coloca que, embora o critério da subordinação não tenha perdido sua essencialidade para a caracterização e amparo das relações de emprego, é preciso reavaliar a presença de outros elementos, da pessoalidade, da permanência e da continuidade em outros tipos de relações de trabalho para que estas passem a ser amparadas pelo Direito do Trabalho. Presencia-se o alargamento das formas de trabalho dependente a transcender o modelo tradicional clássico e o Direito do Trabalho deve atuar de uma forma mais dinâmica, inovadora e transformadora. Admite, assim, que na interpretação da norma, o juiz, para fazer valer os ditames constitucionais, pode, dependendo do caso concreto, estender os direitos previstos no art. $7^{\circ}$, da Constituição Federal às diferentes formas de relações jurídicas desencadeadas em razão do avanço tecnológico e que se distanciam dos contornos rígidos do clássico contrato de trabalho subordinado ${ }^{204}$.

Gabriela Neves Delgado propõe uma ampliação da consciência axiológica para que seja protegido todo e qualquer trabalho digno e não apenas o trabalho

201 PROSCURCIN, Pedro. Do contrato de trabalho ao contrato de atividade: nova forma de regulação das atividades no mercado de trabalho. São Paulo: Ltr, 2003, p. 340-360.

202 Op. cit., p. 361.

${ }^{203}$ A construção da concepção tricotômica: autonomia, subordinação e parassubordinação. In FILHO, Jorge Cavalcanti Boucinhas e BERARDO, Carlos Francisco (organizadores). Novos dilemas do trabalho, do emprego e do processo do trabalho. São Paulo: Ltr, 2012, p. 98

204 GOMES, Dinaura Godinho Pimentel. Op. cit., p. 28, 135-141. 
formal. Partindo do pressuposto de que somente o trabalho digno é capaz de construir uma identidade social do trabalhador, entende que os direitos de indisponibilidade absoluta devem ser assegurados a todo e qualquer trabalhador. $\mathrm{O}$ art. $7^{\circ}$, caput, da Constituição Federal ao fazer referência a "trabalhadores", abre a possibilidade de extensão pelo menos de parte do Direito do Trabalho a grupos não empregatícios de trabalhadores. Este ramo do Direito deve, assim, excluir de seu âmbito somente relações que não sejam capazes de dignificar o homem, como ocorre com o trabalho escravo ${ }^{205}$.

Quanto à regulamentação, admite a autora a preservação de um modelo jurídico mais complexo e minucioso voltado à relação de emprego. Porém, sem prejuízo deste modelo, normas trabalhistas garantidoras de vantagens jurídicas reconhecidas como de indisponibilidade absoluta devem ser estendidas a toda prestação de trabalho, ainda que haja patamares distintos de proteção jurídica às relações de trabalho conforme peculiaridade de cada uma delas. Com isto, busca-se uma universalização de direitos trabalhistas para diversificados tipos de trabalhadores, além do empregado ${ }^{206}$.

"Ressalte-se que a presença de patamares distintos de proteção não significa o respaldo a discriminações entre trabalhadores $e$ entre tipos de relações de trabalho. Significa, somente, o respeito a pluralidade típica da vida social, o respeito à diferença substantiva entre os diversos tipos de vínculo de trabalho ${ }^{207}$,"

Paulo Gustavo de Amarante Merçon vê na regulamentação das relações de trabalho lato sensu uma possibilidade de assegurar inclusão social aos trabalhadores não empregados, bem como uma possibilidade de combate à fraude e à precarização das relações de emprego, já que estas práticas se valem do vazio normativo que cerca o trabalhado autônomo. Entende ser mais adequada uma extensão normativa parcial e escalonada considerando as peculiaridades de cada relação de trabalho, o que não significa criar subclasses de trabalhadores ou criar elementos de discriminação ${ }^{208}$.

Posicionamento semelhante é o adotado por Tabajara Medeiros de

205 DELGADO, Gabriela Neves . Op. cit., p. 203-220.

206 Ibidem, p. 203-220

207 Ibidem, p. 219.

208 Além dos portões da fábrica - o Direito do Trabalho em reconstrução. In Revista Ltr., vol. 71, nº 10, outubro de 2007, p. 1185. 
Rezende Filho, que defende a criação de um núcleo mínimo de direitos trabalhistas com incidência automática a toda contratação de serviço humano prestado por pessoa física, ainda que a pactuação seja efetivada fora do âmbito da relação de emprego. O aumento da regulamentação do trabalho em geral, considerando o autônomo e o parassubordinado, não significa a extinção do trabalho subordinado ou a diminuição da sua esfera de atuação. Pelo contrário, a existência desta regulamentação legal, além de contribuir para a melhoria das condições pessoais dos trabalhadores autônomos e atípicos, constitui medida de combate da fraude trabalhista. $\mathrm{O}$ autor se posiciona contrariamente ao alargamento do conceito de subordinação jurídica ou à interpretação ampliativa dos requisitos para o reconhecimento do vínculo empregatício, o que implicaria na aplicação de normas jurídicas a realidades distintas ${ }^{209}$.

Ao defender que o Direito do Trabalho deve se expandir para abarcar os novos contratos de trabalho tidos como precários ou atípicos, sem menosprezar o clássico vínculo de emprego, Marcus de Oliveira Kaufmann coloca que a parassubordinação serve de manto para que este ramo do Direito passe a se preocupar com variadas formas de relação de trabalho. Ela não pretende e nem pode substituir o conceito de subordinação jurídica, mas a ela se acopla, concedendo aos trabalhadores submetidos a diversas relações de trabalho algum tipo de proteção, que no caso brasileiro, depende de previsão legal. Um moderno Direito do Trabalho deve expandir seu âmbito de atuação alcançando as prestações autônomas e um universo gigantesco de profissionais; deve conceder um mínimo indispensável de tutela necessário à dignificação de todas as formas de trabalho e ocupações humanas; caminhar com enfoque na parassubordinação afastando-se da prevalência da subordinação jurídica; instituir um regime de parassubordinação, tutelável pelo mínimo legal, principalmente no campo da seguridade social ${ }^{210}$.

209 REZENDE FILHO, Tabajara Medeiros de. Do protecionismo do empregado à proteção do trabalhador: desafios da flexicurity. Tese de Doutorado em Direito do Trabalho apresentada na Faculdade de Direito da Universidade de São Paulo. Orientador: Prof. Nelson Mannrich, São Paulo, 2013, p. 122-130 e 137. Entende que a melhor interpretação a ser dada à Constituição é aquela que reconhece a todos os trabalhadores os direitos enunciados no seu art. $7^{\circ}$, pois desta forma haverá uma valorização do trabalho e o respeito à dignidade humana. Reconhece, entretanto, que alguns direitos não se aplicam a determinadas formas de trabalho por não serem compatíveis. Ao analisar cada um dos incisos do art. $7^{\circ}$, da Constituição Federal, conclui que seriam aplicáveis a outras formas de relação de trabalho (que não são relação de emprego), ainda com necessidade de adaptação legal, os incisos II, III, IV, VI, VII, VIII, IX, XII, XIII, XIV, XV, XVI, XVII, XVIII, XIX, XXIII, XXIV, XXV, XXVI, XXVII, XXVIII, XXX, XXXI, XXXII e XXXIII (Op. cit, p. 105-117)

210 Por uma nova dogmática do Direito do Trabalho: implosão e perspectivas. In Revista Ltr, vol. 70, n.02, fevereiro de 2006, p. 245-249. 
Em outras palavras, a grande questão vivenciada diz respeito à extensão de direitos trabalhistas a outros trabalhadores que não são necessariamente subordinados, mas que merecem uma proteção por dependerem economicamente do tomador de serviços. O rompimento do tipo contratual tradicional e o surgimento de novos negócios jurídicos envolvendo a prestação pessoal de serviços decorrem de vários fatores que interessam não só ao tomador de serviços, mas também ao próprio trabalhador (como a possibilidade de realizar suas atividades em casa, com maior flexibilidade de horário $)^{211}$.

Faz-se necessário repensar o Direito do Trabalho para que este passe a incluir em seu âmbito trabalhadores formalmente autônomos, mas substancialmente hipossuficientes, ou seja, pessoas físicas que, sem estrutura empresarial própria, encontram-se vinculadas ao objeto principal ou adjacente de empresa ou cliente, por meio de contratos civis de prestação de serviços, de forma não eventual, onerosa e sem empregados. Seu grande desafio é se adequar às mudanças sem suprimir direitos historicamente conquistados ${ }^{212}$.

Ao abranger as chamadas relações coordenadas, o Direito do Trabalho cumpre sua função constitucional de inclusão social, redução das desigualdades, proteção ao trabalho e à dignidade da pessoa humana ${ }^{213}$.

“ A abrangência do trabalho autônomo e a falta de regulação legal obrigam-nos a aprender com a experiência estrangeira, inclusive no que tange às reformas trabalhistas adotadas até a definição do trabalho parassubordinado, como forma de melhor efetivar ditames de valorização social do trabalho e de dignidade da pessoa humana ${ }^{214 "}$.

${ }^{211}$ NAHAS, Tereza C., Considerações a respeito da relação de trabalho - a questão do trabalho semidependente. In Revista Ltr, vol. 71, no 09, setembro de 2007, p. 1091-1092.

${ }^{212}$ GOULARD, Rodrigo Fortunato. Op. cit., p. 174 e 182. A necessidade de uma releitura do Direito do Trabalho também é defendida por Joselita Nepomuceno Borba, que menciona posição doutrinária defensora da utilização da expressão contrato de atividade, que melhor se adequaria ao novo perfil daqueles que trabalham dentro ou fora da empresa, mas que têm os resultados apropriados por esta. Esse contrato de atividade vai além da noção de trabalho assalariado para abranger o estado profissional da pessoa, incluindo todas as relações laborais. Com isso, aumenta-se o campo da tutela para incluir outras modalidades de trabalho para a empresa (Subordinação jurídica. Parassubordinação. Contrato de atividade: a busca de uma nova dogmática, para a relação de trabalho. In Revista de Direito do Trabalho, n. 116, ano 30, outubro-dezembro 2004, p. 245-246).

${ }^{213}$ GOULARD, Rodrigo Fortunato. Op. cit., p. 188.

${ }^{214}$ GONÇALVES, Leandro Krebs. Os direitos constitucionais do trabalhador autônomo. Texto publicado no Caderno 14, da Anamatra IV, disponível no site http://www.amatra4.org.br/cadernos/264-caderno-14? 
Neste mesmo sentido, posiciona-se Murilo Carvalho Sampaio Oliveira, para quem o debate a respeito da proteção do trabalhador parassubordinado se funda em sua debilidade econômica, resgatando a natureza do Direito do Trabalho de proteção aos trabalhadores hipossuficientes como imperativo de justiça social e como forma de garantir a dignidade humana e o valor social do trabalho. Propõe o autor uma nova hermenêutica para que a pessoa protegida pelo Direito laboral seja o trabalhador dependente e não apenas o subordinado, já que o art. $3^{\circ}$, da CLT faz menção à dependência (sem a utilização de adjetivos) e o art. $7^{\circ}$, da CF fala em trabalhadores. Esta nova noção de dependência transita entre a subordinação jurídica e a dependência econômica, que se verifica diante de relações de coordenação entre o trabalhador e a empresa tomadora ${ }^{215}$.

A nova redação dada pela Emenda Constitucional no 45, de 2004 ao art. 114, da Constituição Federal abre espaço para uma nova reflexão sobre o conteúdo das relações de trabalho diante da ampliação da competência da Justiça Trabalhista. A análise a ser desenvolvida deve incluir a revalorização do trabalho autônomo e o desenvolvimento de novas formas contratuais que considerem o trabalho parassubordinado. O Direito do Trabalho, visando a promoção dos direitos humanos fundamentais, deve fornecer instrumentos que tentem garantir o acesso a todos a um trabalho decente ${ }^{216}$.

Os entendimentos doutrinários acima descritos demonstram que o sistema normativo trabalhista tem como objetivo proteger os trabalhadores, conforme expressão utilizada no art. $7^{\circ}$, caput, da Constituição Federal. Se faz necessária uma reinterpretação das normas trabalhistas para que estas possam cumprir os ditames constitucionais no sentido de valorização do trabalho dependente ${ }^{217}$.

A previsão de proteção jurídica, ainda que em graus diferenciados, para diversas relações de trabalho, notadamente as relações de trabalho parassubordinado em que se evidencia uma hipossuficiência do trabalhador, representa uma modernização do

start=2. Acesso 22.07.2013.

215 Subordinação jurídica: um conceito desbotado. In Revista dos Tribunais on line. Thomson Reuters, p. 12-19.

216 SILVA, Otavio Pinto e. As relações de trabalho e a nova competência da Justiça do Trabalho. In Revista do TST, Brasília, vol. 71, n², maio/agosto 2005, p. 238-239.

217 OLIVEIRA, Murilo C. S. A ressignificação da dependência econômica. In Revista do TST, Brasília, Vol. 78, jan/mar 2012, p. 211. Disponível em http://www.tst.jus.br/web/biblioteca/revista-do-tst . Acesso 15.08.2013. 
Direito do Trabalho que, ao ampliar seu âmbito de atuação, permite o acesso ao trabalho decente a outros trabalhadores que não são empregados. 


\section{CAPÍTULO 3 - TRABALHO PRESTADO POR PESSOAS JURÍDICAS}

\subsection{Considerações iniciais.}

Conforme já analisado, as exigências de competitividade e qualidade, a globalização, as novas tecnologias, a sociedade da informação desconcentram o processo produtivo, valorizam o trabalho de alta qualificação e estimulam novas formas de contratação de serviços. Revalorizam-se os contratos civis e a necessidade de se estabelecer um diálogo entre o Direito Civil e o Direito do Trabalho. Neste contexto, o trabalhador com uma qualificação sofisticada e espírito empreendedor mostra-se menos confortável com os estreitos limites da relação de emprego. Por outro lado, a grande empresa, atualmente, opta pelo mercado de bens e serviços terceirizados, ao invés de contratar empregados ${ }^{218}$. Com isso, verifica-se um crescimento significativo de empresários em nome individual que prestam múltiplos serviços às empresas, que anteriormente eram desempenhados por trabalhadores, de sorte que os novos modelos contratuais no Direito Comercial surgem como uma tendência relevante ${ }^{219}$.

Assim, muitas vezes, a mesma atividade pode ser exercida tanto por pessoas singulares como por pessoas jurídicas. Neste caso, não se está diante de uma relação laboral, mas de um contrato de prestação de serviço, eis que, para o Direito do Trabalho, o trabalhador deve ser pessoa física (e exercer atividade com subordinação). $\mathrm{O}$ recurso a pessoas coletivas para o exercício de tarefas que seriam, por via de regra, exercidas pelo trabalhador é, em princípio, lícito. A exteriorização das atividades não é necessariamente ilícita, dependendo dos contornos em que se materializam ${ }^{220}$.

Sérgio Pinto Martins coloca que a terceirização é lícita, pois, de acordo

218 ROBORTELLA, Luis Carlos Amorim, PERES, Antonio Galvão. Op. cit., p. 122-123.

219 MARTINEZ, Pedro Romano. Exigências de um novo direito do trabalho. In MARTINS, Ives Gandra da Silva, CAMPOS, Diogo Leite de (coordenadores). O direito contemporâneo em Portugal e no Brasil. São Paulo: Saraiva, 2004, p. 374-375 e 383 a 384. Conclui que estas alterações no mundo empresarial têm de ser entendidas sem ideias preconcebidas, mas é sabido que em uma sociedade organizada em torno do trabalho subordinado não se pode alterar de imediato e profundamente esta estrutura. Também, não se deve remar contra a maré.

220 Ibidem, p. 374-375 e 383-384. 
com o disposto no art. 594, do Código Civil, "toda espécie de serviço ou trabalho lícito, material ou imaterial, pode ser contratada mediante retribuição”. Poderá ser considerada ilegal ou ilícita se se referir a locação permanente de mão de obra, ensejando fraudes e prejuízos aos trabalhadores ${ }^{221}$.

A tendência atual é não criar empecilhos para as atividades dos profissionais efetivamente autônomos. A proteção trabalhista homogênea, que não reconhece diferenças entre os diversos prestadores de serviços, pode se mostrar injusta. Isto porque profissionais de extrema especialização e conhecimento não podem ser submetidos à homogeneidade da relação trabalhista, como se fossem empregados, quando, no livre exercício de sua autonomia de vontade, trabalham em regime de autonomia ou constituem empresas prestadoras de serviços. A diferença de tratamento jurídico mostra-se relevante ao prever níveis de proteção para os diversos tipos de inserção do trabalho no mercado e o ordenamento jurídico brasileiro possibilita, com razoável segurança jurídica, novas formas de contratação de serviços, inclusive por meio de pessoa jurídica, sem a tutela da legislação trabalhista ${ }^{222}$.

Com efeito, certos trabalhadores como artistas, jornalistas, criam uma série de vínculos que não se limitam a prestar serviços subordinados. Nessa relação, não cabe mais a CLT, e, menos ainda, a proteção típica dos chamados hipossuficientes ${ }^{223}$. A criação de uma pessoa jurídica por um prestador de serviços científicos, artísticos e culturais, ainda que de pequeno porte, vai muito além de um mero planejamento fiscal, pois se revela como a forma mais adequada ao desempenho de uma atividade livre, desenvolvida com autonomia em relação ao tomador dos serviços, em que o conhecimento e a criatividade do prestador não podem ser controlados pelo contratante ${ }^{224}$.

${ }^{221}$ A terceirização e o Direito do Trabalho. $9^{\mathrm{a}}$ ed. Rev. e ampl. São Paulo: Atlas, 2009, p.157. Embora reconheça posicionamento jurisprudencial consolidado na Súmula 331, do TST no sentido de afastar a terceirização nas atividades fins da empresa, referido autor coloca que não se pode afirmar que a terceirização deva se restringir às atividades meio. Esta decisão deveria ficar a cargo do administrador, desde que a terceirização seja lícita, em homenagem ao princípio da livre iniciativa contido no art.170, da CF. Traz o exemplo da indústria automobilística que delega serviços de atividade fim, eis que as montadoras se concentram na montagem do veículo, no marketing, nas vendas e na elaboração de projetos, sendo que quase tudo é terceirizado. Na construção civil, atividades essenciais ligadas à construtora como fundação, pintura e colocação de azulejos são também terceirizadas.

222 ROBORTELLA, Luis Carlos Amorim, PERES, Antonio Galvão. Op. cit., p. 130-139.

223 MANNRICH, Nelson, Relações de trabalho autônomo e subordinado: proposta para instituir critérios para sua distinção. In BRAMANTE, Ivani Contini, CALVO, Adriana (organizadores). Aspectos polêmicos e atuais do direito do trabalho. São Paulo: Ltr, 2007, p. 154.

224 RIBEIRO, Ricardo Lodi. A natureza interpretativa do art. 129 da Lei 11.196/2005 e o combate à elisão abusiva na prestação de serviços de natureza científica, artística e cultural. In ANAN JR, Pedro, 
Portanto, as formas de atividade autônoma podem ser desempenhadas tanto por uma pessoa física, como normalmente é feito pelos profissionais liberais, pequenos artífices, quanto podem ser desempenhadas sob a forma de pessoa jurídica, unipessoal ou não, microempresas ou não. Via de regra, a passagem da pessoa física para a pessoa jurídica, quando a atividade econômica do profissional liberal começa a prosperar, é impulsionada por questões de ordem tributária, pois os encargos da pessoa jurídica são menores do que os encargos incidentes sobre a folha de pagamento ou sobre os rendimentos do trabalho de qualquer espécie, não assalariado, mesmo que considerados todos os tributos de cunho nacional, estadual e municipal. Dessa forma, as pessoas jurídicas estão fora da proteção do direito do trabalho, ainda que se trate de um ente pequeno, uma empresa unipessoal, um microempresário, ou uma associação sem fins lucrativos $^{225}$.

\subsection{O artigo 129, da Lei 11.196/2005.}

A Lei 11.196/2005, apelidada como Lei do Bem (resultado da conversão da Medida Provisória 255, de 2005), dispõe em seu artigo 129, caput, que:

Art. 129. Para fins fiscais e previdenciários, a prestação de serviços intelectuais, inclusive os de natureza cientifica, artística ou cultural, em caráter personalíssimo ou não, com ou sem a designação de quaisquer obrigações a sócios ou empregados da sociedade prestadora de serviços, quando por esta realizada, se sujeita tão-somente à legislação aplicável às pessoas jurídicas, sem prejuizo da observância do disposto no art. 50 da Lei $\mathrm{n}^{\circ} 10.406$, de 10 de janeiro de

PEIXOTO, Marcelo Magalhães (coordenadores). Prestação de serviços intelectuais por pessoas jurídicas: aspectos legais, econômicos e tributários. São Paulo: MP Ed, 2008, p. 443.

${ }^{225}$ SILVA, Homero Batista Mateus da. Op. cit., p. 11-17. Anota-se, a este ponto, a posição de Sergio Pinto Martins que define trabalhador autônomo como sendo a pessoa física que presta serviços habitualmente por conta própria a uma ou mais de uma pessoa, assumindo os riscos de sua atividade econômica. Para referido autor, o trabalhador autônomo necessariamente é pessoa física, de sorte que não pode o serviço ser desempenhado por pessoa jurídica. (Trabalhador autônomo. In Revista Ltr, vol 69, $\mathrm{n}^{\circ} 02$, fevereiro de 2005, p. 158). 
2002 - Código Civil.

Em sua redação original, referido artigo continha um parágrafo único que dispunha: "O disposto neste artigo não se aplica quando configurada relação de emprego entre o prestador de serviço e a pessoa jurídica contratante, em virtude de sentença judicial definitiva decorrente de reclamação trabalhista". No entanto, este dispositivo foi objeto de veto pelo Presidente da República, cujas razões, expressas na Mensagem 783, de 21 de novembro de 2005, se basearam no fato de que "o parágrafo único do dispositivo em comento ressalva da regra estabelecida no caput a hipótese de ficar configurada relação de emprego entre o prestador de serviço e a pessoa jurídica contratante, em virtude de sentença judicial definitiva decorrente de reclamação trabalhista. Entretanto, as legislações tributária e previdenciária, para incidirem sobre o fato gerador cominado em lei, independem da existência de relação trabalhista entre o tomador do serviço e o prestador do serviço. Ademais, a condicionante da ocorrência do fato gerador à existência de sentença judicial trabalhista definitiva não atende ao princípio da razoabilidade,"226.

O artigo 129, que autoriza a contratação de certos profissionais para prestar serviços intelectuais por meio de pessoa jurídica, deve ser analisado em face das tendências do Direito do Trabalho, cujo desafio é garantir a eficácia econômica sem prejuízo da proteção de quem trabalha ${ }^{227}$. Verifica-se que a Consolidação das Leis do Trabalho nem sempre alcança o hipossuficiente, que acaba se inserindo na informalidade. Por outro lado, o trabalhador intelectual bem situado no mercado não deseja ter sua atividade submetida aos ditames celetistas. Daí a necessidade de providências legislativas que permitam aos profissionais a liberdade de contratar sob outras formas que não as trabalhistas ${ }^{228}$.

Com a edição dessa lei e o debate travado em torno da Emenda 3 da Lei

\footnotetext{
226 Mensagem $\mathrm{n}^{\mathrm{o}} 783$, de 21 de novembro de 2005, disponível em http://www.planalto.gov.br/ccivil 03/ Ato2004-2006/2005/Msg/Vep/VEP-0783-05.htm, acesso, 26.02.2012.

227 MANNRICH, Nelson. Contratação de serviços intelectuais por meio de pessoa jurídica: mitos e realidades. In Revista do Advogado, ano XXVI, n. 86, julho de 2006, p. 61.

228 LIMA, Francisco Meton Marques de. A prestação de serviços sem vínculo de emprego - Lei 11.195/2005: o retorno ao princípio da autonomia da vontade. In Revista do Tribunal Regional do Trabalho da 22 Região, Teresina, v. 4, n.1, jan/dez 2007, p. 64-66. Disponível em http://portal.trt22.jus.br/site/arquivos/downloads/revista 2 54506.pdf\#page=64, acesso 26.02.2012.
} 
$n^{\circ} .11 .457 / 07^{229}$, registra-se uma tendência à liberação contratual entre os profissionais que não se enquadram na categoria de hipossuficientes, valorizando-se a autonomia da vontade e a liberdade contratual. Por outro lado, nota-se que, uma vez caracterizados os elementos de uma relação de empego, deve esta relação prevalecer com a desconsideração da pessoa jurídica ${ }^{230}$.

Em outras palavras, os trabalhadores intelectuais, aqueles cujo trabalho pressupõe uma cultura científica ou artística, podem exercer suas atividades na condição de empregados ou como autônomos. Alice Monteiro de Barros coloca que as partes, no exercício de sua autonomia contratual, podem excluir a subordinação, ao regular seus interesses recíprocos, não sendo possível ao juízo atribuir qualificação diversa à relação jurídica, quando presentes elementos compatíveis com a subordinação e com a autonomia. No entanto, se a forma pela qual se realizou a prestação de serviços for incompatível com a intenção declarada pelas partes e revelar os pressupostos fáticos de uma relação de emprego, a fraude deverá ser reconhecida com as consequências jurídicas pertinentes. $\mathrm{O}$ ônus da prova da situação diversa daquela resultante do contrato compete à parte que $\operatorname{alegar}^{231}$.

São colocados como pressupostos para a aplicação do artigo 129, da Lei 11196/2005 os seguintes elementos: a) a existência de um contrato de prestação de serviços regulado pelo Código Civil; b) que os serviços tenham natureza intelectual, dentro do qual se incluem o trabalho científico, artístico e o cultural; c) a constituição de uma pessoa jurídica pelos prestadores de serviços; d) a prestação dos serviços intelectuais pode ser feita pessoalmente pelo sócio da pessoa jurídica ou por terceiros por ele

229 No projeto de Lei $n^{\circ}$ 6.272/05, que criou a Super Receita, foi inserida, pelo Legislativo, a Emenda 3, que dispunha caber somente ao Poder Judiciário a desconsideração da pessoa jurídica, ato ou negócio jurídico que leve ao reconhecimento de relação emprego. Referido projeto de lei foi convertido da Lei 11.457/07 que acrescentou o parágrafo $4^{\circ}$, ao art. $6^{\circ}$, da Lei 10.593/02 com a seguinte redação: "No exercício das atribuições da autoridade fiscal de que trata esta Lei, a desconsideração da pessoa, ato ou negócio jurídico que implique reconhecimento de relação de trabalho, com ou sem vínculo empregatício, deverá sempre ser precedida de decisão judicial". Na realidade, referido dispositivo repetia o disposto no parágrafo único, do art. 129 , da Lei $11.196 / 05$. Referido $\S 4^{\circ}$, do art. $6^{\circ}$, da Lei $10.593 / 02$ foi vetado diante das manifestações contrárias a este dispositivo. (HARADA, Kiyoshi. Super Receita. Veto à Emenda 3. Uma tremenda confusão mental. Disponível em http://jus.com.br/artigos/9793/super-receita-veto-a-emenda-3 . Acesso 26.12.2013.

${ }^{230}$ LIMA, Francisco Meton Marques de. Op. cit, p. 66-67.

231 BARRROS, Alice Monteiro de. Trabalhadores intelectuais: subordinação jurídica. Redimensionamento. In Revista de direito do Trabalho, n. 115, ano 30, julho a setembro de 2004, Editora Revista dos Tribunais, p. 28-29 e 41. 
designados, inclusive na qualidade de empregado da pessoa jurídica; e) não caracterização de uma relação de emprego ${ }^{232}$.

Além disso, esta modalidade contratual rege-se pelo disposto nos artigos 593 a 609, do Código Civil, sobre a prestação de serviços. Considerando que as profisssões exercidas sob o caráter intelectual, artístico, cultural e científico são cada vez mais presentes e crescentes no mercado, o artigo 129 da Lei 11.196/2005 alberga relações de trabalho expressivas, que representam milhões de postos de trabalho e elevada cifra tributária $^{233}$.

\subsubsection{Da existência de um contrato de prestação de serviços de natureza intelectual regulado pelo Código Civil.}

O desenvolvimento natural dos contratos de prestação de serviço mostrase necessário para o avanço da sociedade moderna, o que torna necessária uma clara separação entre a prestação de serviço do direito civil (que é realizada com independência técnica e sem subordinação) e o contrato de trabalho regulado pela legislação trabalhista que se fundamenta na subordinação. Assim, a prestação de serviços pode ser identificada através dos seguintes elementos: a) o prestador de serviço realiza uma atividade sem subordinação; b) o prestador de serviço pode ser tanto uma pessoa física como jurídica; c) o serviço pode ser realizado de uma forma eventual ou mesmo habitual a um determinado contratante; d) a prestação de serviço pode ser realizada de maneira personalíssima ${ }^{234}$.

Atualmente, a prestação de serviço reflete uma atividade especializada, no sentido de que o serviço exige certa habilidade ou conhecimento específico para a sua realização, pois o prestador de serviço deve ser profissional especialmente treinado e experiente ou com formação acadêmica para tal mister. Além disso, a prestação de serviço compreende o fornecimento de uma atividade lícita, realizada sem subordinação e com liberdade técnica por parte de quem presta o serviço mediante retribuição ${ }^{235}$. A

${ }^{232}$ LIMA, Francisco Meton Marques de. Op. cit., p. 68. CAVALCANTE, Jouberto de Quadros Pessoa, JORGE NETO, Francisco Ferreira. Aspectos do artigo 129, da Lei 11.196. Da terceirização e do Direito do Trabalho. In Revista do TRT da 15 Região, n. 27, jul/dez de 2005, p. 183. Disponível em http://www.trt15.jus.br/escola_da_magistratura/Rev27Art10.pdf, acesso 26.02.2012.

${ }^{233}$ LIMA, Francisco Meton Marques de. Op. cit., p. 65-66

${ }^{234}$ SALOMO, Jorge Lages. A nova realidade da prestação de serviço. In Questões controvertidas no novo Código Civil. São Paulo: Editora Método, 2003, p. 227-230.

${ }^{235}$ SALOMO, Jorge Lages. Op. cit., p. 230-233. 
remuneração é elemento essencial da prestação de serviços, não se podendo, de modo algum, presumir a gratuidade. Assim, o acordo de vontades, gerador do contrato, deve abranger o respectivo objeto, sua natureza, as pessoas que nele intervêm, a duração e retribuição ajustada ${ }^{236}$.

Quanto à natureza intelectual do serviço, tem-se que o profissional intelectual, em sua atividade criadora, pode produzir bens, como fazem os artistas, ou pode produzir serviços, como os profissionais liberais, de sorte que o esforço criador se implanta na própria mente do autor ${ }^{237}$. A atividade do profissional intelectual é uma atividade criadora, que se distingue da profissão de empresário por uma valoração social diversa e à qual se aplicam princípios específicos como: a) o acesso à profissão não é livre, como na atividade empresarial, pois depende de formação intelectual muito mais severa e de regular inscrição na respectiva corporação, por vezes com submissão a rigorosos exames; b) imperam premissas de decoro, que impedem a livre concorrência, tal como a existente entre os empresários; c) por mais que os serviços prestados possam ser, muitas vezes, repetitivos, inexiste produção em massa característica da atividade empresarial ${ }^{238}$.

O artigo 129, da Lei 11.196/2005 fala em "prestação de serviços intelectuais, inclusive os de natureza científica, artística ou cultural".

Segundo Edmar Oliveira Andrade Filho, a determinação da natureza científica de algo depende do que se entende por científico. Trata-se de uma ideia altamente plástica, na qual pode ser considerada toda e qualquer forma de saber que possa ser sistematizada ou explicada de forma racional. Já um serviço de natureza artística é aquele que diz respeito às belas artes, que são, genericamente, artes plásticas, poesia e a dança. Quanto aos serviços de natureza cultural, deve-se considerar que o termo cultura engloba as ideias de artes e tudo quanto é útil ou estimado por uma determinada comunidade. Trata-se, portanto, de conceitos significativamente amplos cujos limites só podem ser estabelecidos pela legislação. Na ausência desta, a interpretação, segundo este

${ }^{236}$ MONTEIRO, Washington de Barros. Curso de direito civil: direito das obrigações. Volume 5: $2^{\mathrm{a}}$ parte. 34. ed., revista, atualizada por Carlos Alberto Dabus Maluf e Regina Beatriz Tavares da Silva. São Paulo: Saraiva, 2003, p. 216.

${ }^{237}$ MARCONDES, Sylvio. Questões de direito mercantil. Saraiva, 1977, p. 11.

${ }^{238}$ AZEVEDO, Erasmo Valladão e FRANÇA, Novaes. Sociedade que tem por objeto a prestação de serviços de natureza intelectual é de natureza simples, qualquer que seja a forma de sua organização. In Revista de Direito Mercantil, industrial, econômico e financeiro, n. 157, janeiro - março/2011, Malheiros Editores, p. 246-245. 
autor, deve ser a mais abrangente possível ${ }^{239}$.

\subsubsection{Considerações sobre a forma societária, antes do advento da Lei 12.441/2011.}

De acordo com o Código Civil, as sociedades são classificadas como sociedades simples e empresárias. A expressão sociedade simples assume dois sentidos, um relacionado à natureza da sociedade (que a distingue da sociedade empresária), outro relacionado a uma das espécies (forma ou tipo) de sociedade. A sociedade simples (não empresária) pode assumir a forma típica da sociedade simples, ou qualquer outra forma societária, exceto as sociedades por ações. A sociedade empresária, por seu turno, pode assumir qualquer forma societária, exceto a forma de sociedade simples. A empresa é a atividade econômica organizada para a produção ou a circulação de bens ou de serviços e empresário é aquele que exerce profissionalmente referida atividade (artigo 966, do Código Civil $^{240}$.

As sociedades simples são aquelas que não dispõem de uma estrutura organizacional e as que, mesmo dispondo, dedicam-se a atividades intelectuais, a atividades rurais (agricultura e pecuária) e a negócios de pequeno porte (pequena empresa) cabendo registrá-las no Registro Civil das Pessoas Jurídicas. Já as sociedades empresárias são todas as demais, inclusive a sociedade dedicada à atividade rural, contanto que se inscreva no Registro Público de Empresas Mercantis ${ }^{241}$.

O Código Civil, em seu artigo 966, parágrafo único, afasta a qualidade de empresário àquele que exerce profissão intelectual, de natureza científica, literária ou artística, ainda com o concurso de auxiliares ou colaboradores, salvo se o exercício da profissão constituir elemento de empresa.

São os chamados profissionais liberais cujas atividades, em razão de uma tradição que as considera qualitativamente distinta da atividade econômica, representam um trabalho pessoal, salvo quando constituem elementos da empresa. $\mathrm{O}$ intelectual cria e o resultado desta emanação do espírito não seria assimilável ao processo produtivo. Assim, todas as sociedades que se dediquem à criação intelectual serão sociedades simples,

\footnotetext{
${ }^{239}$ Análise estrutural e teleológica do enunciado do art. 129 da Lei 11.196/05. In ANAN JR, Pedro e PEIXOTO, Marcelo Magalhães (coordenadores). Prestação de serviços intelectuais por pessoas jurídicas: aspectos legais, econômicos e tributários. São Paulo: MP Ed, 2008, p. 510-511.

240 BORBA, José Edwaldo Tavares. Direito Societário. 9a ed. Rio de Janeiro: Renovar, 2004, p. 09-14.

241 Ibidem, p. 22-23.
} 
independentemente de possuírem ou não uma estrutura organizacional própria de empresa 242.

O trabalho intelectual como elemento de empresa, que constitui a ressalva do parágrafo único do artigo 966, do CC, refere-se a situações em que a atividade profissional intelectual, científica, literária ou artística é absorvida pela atividade empresarial da qual se tornaria um mero elemento. Há, portanto, duas atividades que são realizadas em conjunto, uma intelectual e outra empresarial, ficando a primeira subsumida na segunda, como elemento desta ${ }^{243}$.

Para Rachel Sztajn, o que leva o legislador a excluir das atividades empresariais as profissões intelectuais é a percepção de que algumas prestações são personalíssimas, impedindo que terceiros, quaisquer que sejam, possam substituir o devedor. Assim, mesmo que a atividade seja realizada em conjunto ou com o auxílio de outras pessoas, o regime geral da empresa não pode ser aplicado. Assim, somente nas hipóteses em que a prestação for fungível poder-se-á falar na existência de empresário ou de empresa ${ }^{244}$.

A este respeito, foram elaborados três enunciados adotados na III Jornada de Direito Civil do Conselho de Justiça Federal que assim dispõem:

Enunciado 193: artigo 966: O exercício das atividades de natureza exclusivamente intelectual está excluído do conceito de empresa;

Enunciado 194: artigo 966: os profissionais liberais não são considerados empresários, salvo se a organização dos fatores de produção for mais importante que a atividade pessoal desenvolvida;

Enunciado 195: artigo 966: a expressão "elemento de empresa" demanda interpretação econômica, devendo ser analisada sob a égide da absorção da atividade intelectual, de natureza científica, literária ou

\footnotetext{
${ }^{242}$ BORBA, José Edwaldo Tavares. Op. cit., p. 17-19.

${ }^{243}$ BORBA, José Edwaldo Tavares. Op. cit., p. 17-19. AZEVEDO, Erasmo Valladão e FRANÇA, Novaes. Op. cit., p. 247-248.

244 Notas sobre o conceito de empresário e empresa no Código Civil Brasileiro. In Revista dos Tribunais on line, Thomson Reuters, p. 10.
} 
artística como um dos fatores da organização empresarial.

Tem-se que a pessoa jurídica prestadora de serviços de natureza intelectual de que trata a Lei 11.196/2005 deverá ser constituída sob a forma de uma sociedade simples, nos termos do parágrafo único do artigo 966 , do $\mathrm{CC}^{245}$.

Geralmente, tais sociedades simples costumam ser constituídas por pessoas com participação absolutamente desiguais, apenas para viabilizar seu nascimento. Normalmente, são formadas por uma pessoa, o profissional que trabalha que detém 99,9\% do capital, mais um parente que não trabalha e que tem uma cota apenas para completar a sociedade. Essas pessoas jurídicas vivenciaram um crescimento no país, devido, entre outros elementos, à preferência dos próprios profissionais em função da menor carga tributária e previdenciária e ao próprio sentimento de empreendedorismo ${ }^{246}$.

José Affonso Dallegrave Neto denomina estas pequenas firmas individuais ou pessoas jurídicas que atuam de maneira unipessoal como paraempresas (quase empresa), por se afastarem de conceito legal que vincula a empresa à ideia de organização, pois nelas não estão presentes capital, insumo e tecnologia. São entidades que têm forma de pessoa jurídica e alma de pessoa física pois, na prática, se confundem com o próprio prestador de serviç $0^{247}$.

\subsubsection{Considerações sobre a forma societária, após o advento da Lei 12.441/2011.}

Antes do advento da Lei 12.441/2011, as pessoas naturais que desejassem explorar alguma atividade empresarial poderiam optar entre se tornar empresário individual com responsabilidade ilimitada ou constituir uma sociedade empresária, desde que a legislação não impusesse uma determinada forma (por exemplo, constituição de sociedade anônima para desenvolvimento de atividades bancárias). As

${ }^{245}$ LIMA, Francisco Meton Marques de. Op. cit., p. 65-66, 70. Referido autor observa que, nas situações em que a sociedade prestadora de serviços intelectual possuir caráter empresarial, estar-se-á diante de uma hipótese de terceirização.

${ }^{246}$ PASQUALIN, Roberto. A contratação de pessoa física como jurídica. In Revista de Direito Trabalhista, ano $12, \mathrm{n}^{\circ} 02$, fevereiro de 2006, p. 3.

247 A nova competência trabalhista para julgar ações oriundas da relação de trabalho. In Revista do TST, vol. 71, maio/agosto 2005, p. 244-245. Disponível em http://www.tst.jus.br/web/biblioteca/2005-vol.-71 . Acesso 09.08.2013. 
atividades econômicas de menor porte, pequenos negócios eram, em regra, exercidas por sociedades limitadas, classificadas como micro ou pequenas empresas, conforme variação de sua receita bruta anual. Mas todas deveriam ter dois ou mais sócios ${ }^{248}$.

A Lei 12.441/2011 introduziu o Título I-A, no Livro II, do Código Civil, criando a empresa individual de responsabilidade limitada ("EIRELI"), constituída por uma única pessoa titular da totalidade do capital social (artigo 980-A, do CC).

O objetivo da legislação foi regularizar o empreendedorismo individual, antes disfarçado em falsas sociedades, em um momento em que se avoluma o número de pessoas que, individualmente, concretiza novas ideias no campo da economia ${ }^{249}$. A sua previsão no ordenamento jurídico brasileiro acompanha uma tendência mundial, já que o mesmo modelo é utilizado há anos na Alemanha, França e Portugal e é vista como um marco de apoio e incentivo à formalização de negócios ${ }^{250}$.

Conceitualmente, pode ser definida como sendo "a pessoa jurídica de direito privado, que tem como objeto uma atividade econômica organizada para a produção ou a circulação de bens ou de serviços, e que é constituída por uma só pessoa, cuja responsabilidade é limitada ao montante do capital integralizado ${ }^{251}$ ",

Tem-se, diante do exposto, que a partir da vigência da Lei 12.441/2011, três passaram a ser as alternativas para a exploração da atividade empresarial: tornar-se empresário individual (com responsabilidade ilimitada), constituir uma empresa individual de responsabilidade limitada (EIRELI) ou uma sociedade empresária ${ }^{252}$.

O $\S 5^{\circ}$, do art. 980-A, introduzido no Código Civil pela referida Lei dispõe que "poderá ser atribuída à empresa individual de responsabilidade limitada constituída para a prestação de serviços de qualquer natureza a remuneração decorrente da cessão de direitos patrimoniais de autor ou de imagem, nome, marca ou voz de que seja detentor o titular da pessoa jurídica, vinculados à atividade profissional”.

248 CAVALCANTE, Marcos de Oliveira. Quais as atividades que podem ser exploradas por uma EIRELI (e quais as diferenças entre EIRELI - prestador de serviços - e empregado). In ANAN JR. Pedro, PEIXOTO, Marcelo Magalhães (coordenadores). Empresa Individual de Responsabilidade Limitada EIRELI: aspectos econômicos e legais. São Paulo: MP Ed., 2012, p. 203-204.

249 MARTINS, Ives Gandra da Silva. Lei 12.441 de 11.07.2011. In ANAN JR. Pedro, PEIXOTO, Marcelo Magalhães (coordenadores). Empresa Individual de Responsabilidade Limitada - EIRELI: aspectos econômicos e legais. São Paulo: MP Ed., 2012, p. 106.

250 PEREZ, Julio Linuesa. EIRELI poderá diminuir informais em todo o Brasil. In Jornal Trabalhista Consulex, ano XXIX, no 1410, 23 janeiro de 2012, p. 13.

251 CAVALCANTE, MARCOS DE OLIVEIRA. Op. cit., p. 204.

252 Ibidem, p. 204. 
De acordo com referido parágrafo, pode a EIRELI prestar serviços de qualquer natureza ${ }^{253}$. A nova lei complementa, no plano civil, o disposto no artigo 129, da Lei 11.196/2005, afastando quaisquer dúvidas tributárias sobre se tais sociedades unipessoais deveriam ou não ter tratamento de pessoa jurídica ${ }^{254255}$.

Com isso, afasta-se entendimento antes adotado pela Receita Federal do Brasil no sentido de que se a atividade preponderante de uma sociedade limitada fosse considerada serviço personalíssimo, eis que desempenhado exclusivamente por um dos sócios, não seria possível a tributação sobre a pessoa jurídica, mas sobre a pessoa física. Nesta situação, os rendimentos eram atribuídos à pessoa física do sócio, com a cobrança do imposto de renda respectivo e a incidência de multa de $75 \%$, como sanção à “omissão de rendimentos"256.

A legalização da empresa individual permite superar o artifício de uma sociedade de "faz de conta", o que acontecia quando o profissional empreendedor de diferentes ramos de prestação de serviços ou do setor produtivo, em particular o de trabalho intelectual, de natureza científica, jornalística, cultural e áreas afins se associava a familiar, parente ou amigo, quase sempre sem as mesmas aptidões e interesses para formar uma sociedade fictícia. À EIRELI é reconhecida uma grande importância social e econômica ao se relacionar com expressiva fatia do mercado diante do aumento de profissionais especializados que trabalham como pessoa jurídica e de outros atores econômicos que se organizam como tal ${ }^{257}$.

${ }^{253}$ MONTEIRO, Manoel Ignácio Torres; SOUZA, Glaucia Macedo de. Empresa Individual de Responsabilidade Limitada - aspectos gerais. In ANAN JR. Pedro, PEIXOTO, Marcelo Magalhães (coordenadores). Empresa Individual de Responsabilidade Limitada-EIRELI: aspectos econômicos e legais. São Paulo: MP Ed., 2012, p. 160.

254 MARTINS, Ives Gandra da Silva. Op. cit., p. 110-111.

255 Quanto ao registro, foi elaborada a Nota $n^{\circ} 446$, de 16 de novembro de 2011, pela Cosit (Coordenação Geral de Tributação, da Secretaria da Receita Federal), como resposta à consulta formulada pela Coordenação-Geral de Gestão de Cadastros (Cocad) em que se questionava a possibilidade de a EIRELI ser constituída junto ao Registro Civil de Pessoa Jurídica. A conclusão aponta que, em razão da indefinição da legislação, pelo fato de o $\$ 6^{\circ}$, do art. 980-A, do Código Civil (introduzido pela Lei 12.441/11) permitir à EIRELI a aplicação das normas da sociedade limitada no que couber e pela aplicação analógica ao que se tem hoje positivado sobre o registro da sociedade empresária e simples (ambas podendo ser de responsabilidade limitada), o registro da EIRELI poderá ser feito tanto no Registro Público das Empresas Mercantis pelas Juntas Comerciais como no Registro Civil de Pessoas Jurídicas. (Disponível em http://www.irtdpjbrasil.com.br/EIRELI.COSIT.pdf . Acesso 26.12.2013).

256 BICHARA, Luis Gustavo e OLIVEIRA, Wagner S. Barroso de. Anotações práticas sobre o advento da EIRELI. In ANAN JR. Pedro, PEIXOTO, Marcelo Magalhães (coordenadores). Empresa Individual de Responsabilidade Limitada - EIRELI: aspectos econômicos e legais. São Paulo: MP Ed., 2012, p. 142143.

257 JUNIOR, Pedro Anan e Peixoto, Marcelo Magalhães, Apresentação da obra Empresa Individual de 
A criação da empresa individual está destinada a verdadeiros empreendedores, a prestadores de serviços e profissionais liberais que têm perfil próprio e condições, inclusive financeiras, de se organizarem como uma pessoa jurídica e não ao operário ou ao simples trabalhador travestido de pessoa jurídica apenas para ocultar uma relação de emprego ${ }^{258}$.

A edição da lei surge em um momento em que o Brasil vive um dos mais impressionantes fenômenos de emergência de empresas. Entre 2000 e 2010, o número de empresas no país cresceu 47\%, alcançando 6,2 milhões de negócios. Conforme dados do Banco Mundial, o Brasil cria 316.000 novos negócios por ano, ficando em terceiro lugar como o país mais empreendedor, atrás apenas dos Estados Unidos e Reino Unido (em razão da ausência de dados confiáveis, a China não entrou na pesquisa). A escolaridade dos empreendedores também aumentou: em 2002, 51\% tinha até 04 anos de estudo; em $2010,54 \%$ possui entre 05 a $11 \operatorname{anos}^{259}$.

Em outubro de 2013, apurou-se a existência de 16 milhões de companhias ativas no pais, sendo que, do total, 45,19\% atua no setor de serviços, $41,79 \%$ no comércio, $7,17 \%$ na indústria e $4,24 \%$ ao agronegócio. Pessoas que trabalham por conta própria, incluindo os microempreendedores individuais (MEIs), representam 50,4\% das empresas abertas no país, enquanto as sociedades empresariais correspondem a 34,8\%. O perfil familiar das sociedades é forte, já que apenas $7 \%$ possuem sócios sem grau de parentesco ${ }^{260}$.

Percebe-se, portanto, que o reconhecimento da EIRELI surge em um momento em que a participação do empresário no mundo dos negócios é crescente. A limitação da responsabilidade patrimonial permite a salvaguarda dos direitos autorais e

Responsabilidade Limitada-EIRELI: aspectos econômicos e legais. São Paulo: MP Ed., 2012, p. 14-15.

258 JUNIOR, Pedro Anan e Peixoto, Marcelo Magalhães. Op. cit., p. 18.

Não se desconhece a existência de entendimento doutrinário contrário no sentido de que, sendo a empresa individual de responsabilidade limitada um agente econômico alternativo às pessoas do empresário e da sociedade empresária, o seu objeto deve envolver o exercício de uma atividade econômica organizada própria de empresário para a circulação de bens ou serviços, não podendo, portanto, ter por objeto atividade intelectual de natureza literária, artística ou científica (NETO, Alfredo de Assis Gonçalves, A empresa individual de responsabilidade limitada in Revista dos Tribunais, ano 101, janeiro de 2012, vol 915, p. 160).

259 Reportagem Um país de empreendedores. Revista Exame, edição 1012, ano 46, nº5, 21.03.2012, p. 3842.

${ }^{260}$ Com 16 milhões de empresas, Brasil tem um novo negócio a cada 05 minutos. Disponível em http://economia.ig.com.br/empresas/2013-10-17/com-16-milhoes-de-empresas-brasil-tem-um-novonegocio-a-cada-5-minutos.html . Acesso 30.10.2013 
conexos, próprios do profissional liberal, intelectual e do técnico especializado de nível médio ou superior. Por outro lado, a exigência de integralização de um capital mínimo, além de proporcionar sustentabilidade à empresa, contribui para evitar desvios de finalidade em sua constituição, visando burlar obrigações civis, trabalhistas, tributárias e previdenciárias $^{261}$.

\subsubsection{Da desconsideração da pessoa jurídica}

Passa-se, neste ponto, a uma breve análise sobre a desconsideração da personalidade jurídica a que alude a parte final do artigo 129, da Lei 11.196/2005 sem o intuito de realizar uma análise profunda da questão que envolverá o exercício do poder de fiscalização atribuído à Fazenda Pública, sob pena de se desviar do objeto do presente trabalho.

A teoria da desconsideração da pessoa jurídica foi criada pela doutrina a partir de decisões jurisprudenciais nos Estados Unidos, Inglaterra e Alemanha em que se verificou que a autonomia patrimonial da pessoa jurídica poderia ser utilizada fraudulentamente. Desta maneira, o pressuposto inafastável da despersonalização episódica da pessoa jurídica é a ocorrência de fraude, não sendo suficiente a simples insolvência do ente coletivo. Além disso, a aplicação desta teoria não atinge a validade do ato constitutivo da pessoa jurídica, mas a sua eficácia episódica, de sorte que a separação patrimonial não será aplicada ao caso específico objeto de fraude reconhecido em decisão judicial $^{262}$.

O Código Civil, com o intuito de evitar que a desconsideração se tornasse um instrumento de abuso, indicou os requisitos para a sua deflagração no art. 50, que dispõe: "Em caso de abuso da personalidade jurídica, caracterizado pelo desvio de finalidade, ou pela confusão patrimonial, pode o juiz decidir, a requerimento da parte, ou do Ministério Público quando lhe couber intervir no processo, que os efeitos de certas e

${ }^{261}$ DORNELLES, FRANCISCO. Novas perspectivas para os empreendedores brasileiros. In ANAN JR. Pedro, PEIXOTO, Marcelo Magalhães (coordenadores). Empresa Individual de Responsabilidade Limitada-EIRELI: aspectos econômicos e legais. São Paulo: MP Ed., 2012, p. 86-87.

${ }^{262}$ COELHO, Fabio Ulhoa. Manual de direito comercial. $14^{\mathrm{a}} \mathrm{ed}$. Rev. Atual. De acordo com o novo Código Civil e alterações da LSA e ampl. Com estudo de comércio eletrônico. São Paulo: Saraiva, 2003, p. 126128. 
determinadas relações de obrigações sejam estendidos aos bens particulares dos administradores ou sócios da pessoa jurídica”.

Portanto é necessário um ato abusivo caracterizado pelo desvio de finalidade ou pela confusão patrimonial. $\mathrm{O}$ desvio de finalidade é verificado mediante o desrespeito ou a dissonância do propósito que autorizou a própria constituição da pessoa jurídica. Já a confusão patrimonial caracteriza-se pela utilização efetiva do patrimônio da pessoa jurídica em benefício direto e exclusivo de um dos sócios. Trata-se de uma verdadeira fusão entre as duas esferas patrimoniais em análise $\mathrm{e}^{263}$.

A parte final do disposto no artigo 129, da Lei 11.196/2005 prevê a possibilidade de aplicação do artigo 50, do Código Civil, quanto à desconsideração da personalidade jurídica. Um dos principais objetivos deste dispositivo foi proporcionar segurança aos prestadores de serviços de caráter pessoal que o fazem mediante uma pessoa jurídica. Isto porque era comum serem lavrados autos de infração contra empresas prestadoras de serviços por agentes da Secretaria da Receita Federal, sob a alegação de que, em face da natureza pessoal dos serviços contratados, os rendimentos deveriam ser tributados na pessoa física do sócio. Tais autuações fundavam-se, na prática, no instituto da desconsideração da personalidade jurídica ${ }^{264}$.

Portanto, de acordo com a parte final do disposto no referido artigo 129, uma pessoa jurídica deve ser tratada como tal para fins fiscais e previdenciários não podendo, portanto, ser equiparada a pessoa física, salvo nas hipóteses do artigo 50, do Código Civil, precedida de autorização judicial. Referido entendimento tem por fundamento direitos e garantias assegurados na Constituição e em normas infraconstitucionais como a liberdade de iniciativa, prevista no artigo 170, caput, da CF (princípio constitucional que assegura a todos o poder para organizar seus próprios negócios, conforme lhes sejam convenientes, sem qualquer tipo de ingerência); a liberdade de contratar prevista no art. 421, do Código Civil e a competência material conferida à Justiça do Trabalho de compor os conflitos decorrentes da relação de trabalho, inclusive para reconhecimento de vínculo de emprego (artigo 114, da CF) $)^{265}$.

263 TEPEDINO, Gustavo. Sociedade prestadora de serviços intelectuais: qualificação das atividades privadas no âmbito do direito tributário. In ANAN JR. Pedro, PEIXOTO, Marcelo Magalhães (coordenadores). Prestação de serviços intelectuais por pessoas jurídicas: aspectos legais, econômicos e tributário. São Paulo: MP Ed, 2008, p. 43-45.

264 FILHO, Edmar Oliveira Andrade. Op. cit., p. 482 e 509.

265 JUNIOR, Pedro Anan. Comentários sobre o veto da Emenda 3, que alterava o art. 6 da Lei $n$ 
Na aprovação do Projeto de Lei da Super Receita (atual Lei 11.457, de 16.03.2007), o Presidente da República vetou a chamada Emenda Legislativa $n^{\circ} 03$ ao referido projeto que dispunha: "No exercício das atribuições de autoridade fiscal de que trata esta Lei, a desconsideração da pessoa, ato ou negócio que implique reconhecimento de relação de trabalho, com ou sem vínculo empregatício, deverá ser sempre precedida de decisão judicial". O veto presidencial ensejou grandes discussões quanto à possibilidade de os fiscais da Receita Federal poderem desconsiderar amplamente a personalidade jurídica de determinada sociedade de pessoas para fins de tributação ${ }^{266}$.

Entendimento no sentido de que, com o veto, os fiscais teriam recebido, implicitamente, esta ampla prerrogativa, é incompatível com os ditames da Constituição e com o ordenamento jurídico. Na realidade, a Emenda 3 apenas ecoava o que já estava disposto na Constituição Federal: a liberdade econômica e profissional, seu conteúdo mínimo e os limites do agente fiscal como representante do poder impositivo do Estado no campo tributário. Desde que a pessoa jurídica seja uma entidade legítima e admitida pelo direito, não pode ser vedado o acesso a essa forma de atuar na economia, por questões meramente fiscais ${ }^{267}$.

Não pode ser conferido, à autoridade administrativa, o poder de qualificar, segundo seus próprios critérios, os negócios praticados por pessoas jurídicas prestadoras de serviços. O sistema deve ser construído de modo a privilegiar a autonomia patrimonial, em homenagem ao princípio constitucional da livre iniciativa e buscando, evidentemente, coibir taxativamente fraudes e abusos. Assim, não se mostra possível tratar a autonomia patrimonial da pessoa jurídica como exceção e a desconsideração como regra, fundamentada em presunções de confusão patrimonial. A demonstração, perante a autoridade judicial, da confusão patrimonial e do abuso da personalidade da pessoa jurídica mostra-se indispensável. Em suma, tem-se que, se restar configurada a simulação

10.592/2002, e as autuações fiscais das sociedades prestadoras de serviços. In ANAN JR. Pedro, PEIXOTO, Marcelo Magalhães (coordenadores). Prestação de serviços intelectuais por pessoas jurídicas: aspectos legais, econômicos e tributários. São Paulo: MP Ed, 2008, p. 518 e 525.

266 TAVARES, André Ramos. Liberdade econômica e tributação: o caso da Emenda 3 e a fraude à Constituição. In ANAN JR. Pedro, PEIXOTO, Marcelo Magalhães (coordenadores). Prestação de serviços intelectuais por pessoas jurídicas: aspectos legais, econômicos e tributários. São Paulo: MP Ed, 2008, p. 83-84. ANAN JUNIOR, Pedro. Comentários sobre o veto da Emenda 3, que alterava o art. 6 da Lei $n$ 10.592/2002, e as autuações fiscais das sociedades prestadoras de serviços. In ANAN JUNIOR, Pedro, PEIXOTO, Marcelo Magalhães (coordenadores). Prestação de serviços intelectuais por pessoas jurídicas: aspectos legais, econômicos e tributários. São Paulo: MP Ed, 2008., p. 517.

267 TAVARES, André Ramos. Op. cit., p. 84-86. 
ou fraude, autoriza-se a desconsideração do ato pela autoridade administrativa, submetida, à evidência, ao posterior controle do Judiciário ${ }^{268}$.

Neste sentido, citam-se dois enunciados formulados na $1^{\text {a }}$ Jornada de Direito Material e Processual da Justiça do Trabalho, que assim dispõem ${ }^{269}$ :

Enunciado 56: AUDITOR FISCAL DO TRABALHO. RECONHECIMENTO DA RELAÇÃO DE EMPREGO. POSSIBILIDADE. Os auditores do trabalho têm por missão funcional a análise dos fatos apurados em diligências de fiscalização, o que não pode excluir o reconhecimento fático da relação de emprego, garantindo-se ao empregador o acesso às vias judicial elou administrativa, para fins de reversão da autuação ou multa imposta.

Enunciado 57: FISCALIZAÇÃO DO TRABALHO. RECONHECIMENTO DE VÍNCULO EMPREGATÍCIO. DESCONSIDERAÇÃO DA PESSOA JURÍDICA E DOS CONTRATOS CIVIS. Constatando a ocorrência de contratos civis com o objetivo de afastar ou impedir a aplicação da legislação trabalhista, o auditor-fiscal do trabalho desconsidera o pacto nulo e reconhece a relação de emprego. Nesse caso, o auditor-fiscal não declara, com definitividade, a existência da relação, mas sim constata e aponta a irregularidade administrativa, tendo como conseqüência a autuação e posterior multa à empresa infringente.

Portanto, a apreciação quanto à existência ou não de vínculo empregatício entre duas pessoas continuará sendo atribuição do Poder Judiciário. A fiscalização dos auditores fiscais atua como elemento de pressão e de intimidação

268 TEPEDINO, Gustavo. Op. cit., p. 39-40.

269 Enunciados

extraídos

do

site http://www.nucleotrabalhistacalvet.com.br/novidades/1jornadadedireiro.pdf, acesso 03.06.2012. 
daqueles que insistem em burlar a aplicação das normas trabalhistas ${ }^{270}$.

\subsection{O art. 129, da Lei 11.196/2005 e o Direito do Trabalho.}

Primeiramente, apontam-se alguns pontos de aproximação e de distanciamento entre o disposto no artigo 129, da Lei 11.196/2005 e os requisitos necessários à configuração da relação de emprego, que restaram claramente delineados por Francisco Meton Marques de Lima ${ }^{271}$.

Inicialmente, como elementos de aproximação, tem-se que ambos são contrato de atividade, ou seja, de prestação de serviço continuado; em ambos há a pessoalidade na execução do serviço; em ambos, o serviço é de natureza contínua ou mais ou menos duradoura na tomadora; ambos são onerosos e o trabalho poderá ser prestado nas dependências da contratante.

Por outro lado, ressaltam-se os pontos de divergência capazes de delimitar as duas situações. Nos termos do artigo 129, da Lei 11.196/2005 a atividade é desempenhada mediante uma pessoa jurídica, regida pelo Código Civil, sendo que o trabalhador é autônomo ou parassubordinado. Há uma relação de coordenação entre o tomador e o prestador de serviços, sendo que a sociedade poderá, em casos excepcionais, prestar serviços através de terceiros alheios a seus quadros ou através de seus empregados. Somente o prestador de serviços intelectuais poderá ser contratado nos moldes do artigo 129, da Lei 11.196/2005 ora estudado. Por ouro lado, na relação de emprego, a atividade é desenvolvida por pessoa física, é regida pela CLT e há uma relação de subordinação entre empregado e empregador. Além disso, a pessoalidade do empregado é elemento essencial, inafastável.

Muito se questiona sobre a repercussão do artigo 129, da Lei 11.196/2005 no âmbito do Direito do Trabalho, notadamente se referido artigo pode ser visto como uma forma institucional de precarização das relações de trabalho. Ronaldo Lima dos Santos entende ser este artigo flagrantemente inconstitucional, na medida em

${ }^{270}$ CHAPPER, Alexei Almeida. A questão da pejotização e da informalidade. In Revista da Academia Nacional de Direito do Trabalho - O Direito do Trabalho e a crise econômica e outros estudos, ano XVII, n. 17, Editora Ltr, 2009, p. 217.

271 Op. cit., p. 80. 
que viola o princípio da igualdade insculpido no artigo $5^{\circ}$, inciso $\mathrm{I}^{272}$ e artigo $7^{\circ}, \mathrm{XXX}^{273} \mathrm{e}$ XXXII, ambos da Constituição Federal, sendo que este último dispositivo é peremptório ao prescrever a " proibição de distinção entre trabalho manual, técnico e intelectual ou entre os profissionais respectivos"274.

Para Alexei Almeida Chapper, considerando o caráter cogente das normas trabalhistas, a Lei 11.196/2005 não é capaz de transpô-las. Sendo o trabalhador hipossuficiente, seja o trabalho manual, técnico ou intelectual, a relativa autonomia concedida aos prestadores de serviços intelectuais não é hábil a afastar a aplicação do Direito do Trabalho, diante dos princípios da proteção, da realidade e da irrenunciabilidade das normas trabalhistas ${ }^{275}$.

As recentes transformações do Direito do Trabalho colocam em questionamento antigos padrões como a divisão estanque entre trabalho autônomo e o subordinado, impondo-se a revisitação do próprio princípio da proteção. A ausência de registro do vínculo de emprego não decorre apenas da fraude, mas do não enquadramento da relação ao conceito de emprego, ante a ausência da subordinação típica ${ }^{276}$.

Nem sempre o princípio da proteção consegue atender aos interesses do próprio trabalhador, que almeja a revisão do modelo construído pela CLT que refuta qualquer forma de prestação de serviços que não se enquadre no binômio autonomia e subordinação $0^{277}$.

Embora a precarização possa se evidenciar através da contratação fraudulenta de trabalhadores visando burlar as normas de proteção de emprego, esta não pode ser tida como uma regra geral, como uma forma preconcebida, sob pena de impedir o desenvolvimento natural das relações, esvaziando quaisquer outros tipos de contratação que também têm previsão legal. Evidentemente, não se nega a ocorrência de fraudes,

${ }^{272} \mathrm{O}$ inciso I, do art. $5^{\circ}$, da CF, dispõe: "homens e mulheres são iguais em direitos e obrigações, nos termos desta Constituição".

${ }^{273} \mathrm{O}$ inciso XXX, do art. $7^{\circ}$, da CF dispõe: "proibição de diferença de salário, de exercício de funções e de critério de admissão por motivo de sexo, idade, cor ou estado civil".

${ }^{274}$ SANTOS, Ronaldo Lima dos. Op. cit., p. 99.

275 Op. cit., p. 218.

${ }^{276}$ MANNRICH, Nelson. Inderrogabilidade da norma trabalhista e indisponibilidade de direitos: algumas reflexões. In Revista da Academia Nacional de Direito do Trabalho - O Direito do Trabalho e a Crise Econômica e outros Estudos, , ano XVII, n. 17, Editora Ltr, 2009, p. 78 e 82.

277 BULGUERONI, Renata Orsi. Trabalho autônomo dependente: experiências italiana e espanhola e a realidade brasileira. Dissertação apresentada à banca examinadora da Faculdade de Direito da Universidade de São Paulo como exigência parcial para obtenção do título de Mestre em Direito do Trabalho e Seguridade Social. São Paulo, 2011, p. 195. 
apenas se procura mostrar que um posicionamento que visa atribuir natureza empregatícia a relações próprias de natureza civil, além de anular relações igualmente previstas em lei, promove uma insegurança jurídica ${ }^{278}$.

O objetivo do legislador, em relação ao artigo 129, da Lei 11.196/2005, certamente não foi o de liberar as empresas do jugo da CLT, afastando-as dos encargos dela decorrentes através da substituição de empregados por pessoas jurídicas. Seu intento foi dar segurança jurídica aos prestadores de serviços organizados por pessoa jurídica diante de inúmeras desconsiderações da personalidade jurídica efetivadas por auditores fiscais com o objetivo de exigir o imposto de renda pessoa física e a contribuição previdenciária, como se tais prestadores fossem pessoas físicas autônomas ou empregadas $^{279}$.

É, portanto, perfeitamente lícita a constituição de sociedade para o exercício de atividade intelectual, de natureza científica, literária ou artística sendo frequente o recurso a tal modelo, sem embargo de atuação pessoal do sócio no serviço contratado pela pessoa jurídica. Trata-se da concretização do princípio da livre iniciativa previsto na Constituição Federal (artigo $1^{\circ}$, inciso IV e artigo 170), que permite aos particulares escolher os meios idôneos para o desenvolvimento de uma atividade econômica $^{280}$.

A contratação tradicional apresenta-se insuficiente diante das alterações no mundo do trabalho já descritas, o que faz surgir a necessidade de um novo modelo, agora autorizado pelo artigo 129, da Lei 11.196/2005. Especificamente, pode-se estabelecer uma distinção entre trabalhadores intelectuais e empregados em geral pela sua relação de coordenação e de autonomia ${ }^{281}$. Isto significa entender que as características da prestação de serviços intelectuais quase sempre se afastam da subordinação característica da relação de emprego, uma vez que tais atividades são fruto do espírito livre do prestador, que não é fiscalizado quanto à execução do trabalho, que não se dobra a um

${ }^{278}$ PERES, Celia Mara. A contratação de pessoa jurídica e caracterização de vínculo empregatício. In JOÃO, Paulo Sergio, TEIXEIRA, Pedro Paulo. Temas em direito do trabalho: direito material individual. Vol. I, São Paulo: Ltr, 2008, p.18-19.

279 MANNRICH, Nelson. Contratação de serviços intelectuais por meio de pessoa jurídica. In Revista do Advogado, ano XXVI, n. 86, julho 2006, p. 60. RIBEIRO, Ricardo Lodi. Op. cit., p. 433.

280 TEPEDINO, Gustavo. Op. cit., p. 27.

${ }^{281}$ MANNRICH, Nelson. Contratação de serviços intelectuais por meio de pessoa jurídica. In Revista do Advogado, ano XXVI, n. 86, julho 2006., p. 61. 
acompanhamento técnico do tomador, mas que é controlado pelo seu resultado ${ }^{282}$.

Referido artigo representa uma reforma pontual, que revela o esgotamento do nosso modelo trabalhista ${ }^{283}$. Este dispositivo ganha destaque ao reconhecer, em nosso ordenamento, a existência de trabalhadores que, por suas peculiaridades, podem ser considerados trabalhadores autônomos dependentes. Trata-se de trabalhadores que detêm elevada autonomia no desempenho de suas atividades e que dedicam a maior parte de sua jornada a um único tomador, do qual percebem a maior parte de sua remuneração e com o qual estabelecem uma relação de colaboração ${ }^{284}$.

Conclui-se, dessa maneira, que a constituição de pessoa jurídica para a prestação de serviços intelectuais não representa, por si só, fraude à aplicação da legislação trabalhista. Esta forma de contratação mostra-se como uma adaptação das relações jurídicas às novas exigências impostas pelas recentes alterações na forma de produção e na organização do trabalho.

Isto porque, conforme já mencionado, estes profissionais não se curvam a uma relação de emprego nos moldes do capitalismo industrial, como foi concebida a nossa legislação do trabalho. Tais trabalhadores preferirão uma relação jurídica regida pela legislação civil, que possui mais força de contratualidade, permitindo mais liberdade na manifestação da vontade ${ }^{285}$.

A título exemplificativo, cita-se a situação dos médicos, em que grande parte constitui pessoa jurídica para a prestação de serviços.

Em razão da natureza da atividade prestada, muitas vezes é difícil identificar se um médico é empregado ou autônomo, já que, para atuar, este profissional necessita de certa autonomia, inclusive técnica. É difícil, também, ao dono de uma clínica ou de um hospital exigir subordinação, pois o profissional da área médica não costuma se submeter a determinadas regras. Além disso, em algumas situações não há pessoalidade, já que o médico pode ser substituído por colegas. Por outro lado, na área da saúde é mais comum vislumbrar a fraude na utilização da pessoa jurídica em recepcionistas, auxiliares

${ }^{282}$ RIBEIRO, Ricardo Lodi. Op. cit., p. 436.

${ }^{283}$ MANNRICH, Nelson. Contratação de serviços intelectuais por meio de pessoa jurídica. In Revista do Advogado, ano XXVI, n. 86, julho 2006., p. 62.

${ }^{284}$ BULGUERONI, Renata Orsi. Trabalho autônomo dependente: experiências italiana e espanhola e a realidade brasileira. Dissertação apresentada à banca examinadora da Faculdade de Direito da Universidade de São Paulo como exigência parcial para obtenção do título de Mestre em Direito do Trabalho e Seguridade Social. São Paulo, 2011, p. 196.

${ }^{285}$ LIMA, Francisco Meton Marques de. Op. cit., p.82. 
de enfermagem, técnicos de enfermagem, de radiologia etc, pois estão submetidos à $\operatorname{ordens}^{286}$.

Em Ação Civil Pública movida pelo Ministério Público do Trabalho, cujo objeto era a contratação de médicos por pessoa jurídica (ou na condição de sócios de pessoa jurídica) para a prestação de serviços no setor de diagnóstico por imagem de um hospital, restou afastada qualquer ilegalidade na terceirização, uma vez demonstrado que os médicos não têm interesse para o estabelecimento do vínculo de emprego e que a prática não acarreta prejuízo a estes trabalhadores ou sonegação de direitos com repercussão social. Concluiu-se que o estabelecimento de relação sem vínculo de emprego decorre da própria especialidade da prestação de serviços de radiologia e da forma de organização destes profissionais. Afastada, assim, alegação de fraude deduzida pela Ministério Público (TRT 4 ${ }^{\mathrm{a}}$ Região, Recurso Ordinário, Processo 008680054.2008.5.04.0021, $6^{\mathrm{a}}$ Turma, Juiz Convocado: José Cesário Figueiredo Teixeira, data do julgamento 22.08.2012) $)^{287}$

São encontradas, ainda, outras decisões que afastam o vínculo de emprego nas situações de médicos que prestam serviços por meio de constituição de pessoa jurídica, notadamente em razão da ausência da pessoalidade e da subordinação ${ }^{288}$.

Fora da área da saúde, também há entendimentos jurisprudenciais que admitem a prestação de serviços por pessoas jurídicas sem necessária caracterização de fraude à relação de emprego.

A título de ilustração, no julgamento do processo 01373.2007.261.0200-8 foi reconhecida a prestação de serviços realizada por contador a diversas empresas. No caso, houve a criação de uma pessoa jurídica para a realização do trabalho contábil, com a

286 CARVAlHO, Maria Amélia Lira de. Pejotização e Descaracterização do contrato de emprego: o caso dos médicos em Salvador - Bahia. Salvador, 2010, pp. 121-122. Dissertação de Mestrado apresentada na Universidade Católica de Salvador. Superintendência de Pesquisa e Pós Graduação. Mestrado em Políticas Sociais e Cidadania. Orientação: Professora Doutora Ângela Maria Carvalho Borges. Disponível em http://www.desenvolvimentoqs.ufba.br/sites/desenvolvimentoqs.ufba.br/files/MARIA\%20AMELIA \%20LIRA\%20DE\%20CARVALHO.pdf . Acesso 17.09.2013.

287 Disponível em http://www.trt4.jus.br/portal/portal/trt4/consultas/jurisprudencia/acordaos . Acesso 17.09.2013.

288 TRT 2 a Região, Processo nº: 02910-2003-432-02-00-4 , Relator (a): Rafael E. Pugliese Ribeiro, Data de Publicação: 03/09/2010; TRT 2a Região, Processo no: 04802-2006-081-02-00-6 , Relator(a): Wilma Nogueira De Araujo Vaz Da Silva, Data de publicação: 09/04/2010; TRT4, Recurso ordinário, Processo 000399-53.2011.5.04.0019, $10^{\mathrm{a}}$ Turma, Relator: Denise Pacheco, data 22.08.2013. TRT-2 ${ }^{\mathrm{a}}$ REGIÃO, PROCESSO No: 02247006220105020022, RELATOR(A): FRANCISCO FERREIRA JORGE NETO DATA DE JULGAMENTO: 04/08/2011 
emissão de notas fiscais e incidência tributária correlata. $O$ prestador não estava sujeito a controle de horário, ao recebimento de ordens e seu trabalho não era conferido pelo tomador $^{289}$.

A edição da Lei 11.196/2005 sinaliza a necessidade de uma reelaboração do Direito do Trabalho. O que se depreende, com esta legislação, é que não se pode mais identificar o funcionamento do mercado de trabalho com o critério de assalariamento urbano, sustentado nas grandes empresas. Se faz necessária a constituição de legislação apropriada para distintos segmentos ocupacionais, por meio de uma nova regulação pública que universalize direitos, ainda que de forma não homogênea, mas incorporando todos os trabalhadores. Assim, a questão que se coloca ao Direito do Trabalho é a extensão graduada das tutelas além dos confins da subordinação, partindo de uma disciplina mínima comum a todos os tipos de trabalho (sejam subordinados ou não) e adotando uma visão global e ponderada das modalidades de trabalho criadas com a segmentação dos processos produtivos e com a terceirização dos serviços nas empresas. Isto porque o grande risco que se apresenta para o Direito do Trabalho é o de atingir um número cada vez menor de pessoas em razão do surgimento de novas formas de contratação que ficam à margem desta disciplina, se ela continuar a ser pensada apenas em vista de um tipo de trabalho permanente, prestado sob subordinação e para um só patrão ${ }^{290}$.

Neste mesmo sentido, Cláudio Armando C. De Menezes coloca que o grande debate hoje envolve um Direito do Trabalho não excludente das formas atípicas de trabalho, evitando-se que aquelas pessoas que dependem do trabalho prestado em favor de outrem para sobreviver fiquem fora da proteção das leis estatais e dos ajustes decorrentes de negociação coletiva ${ }^{291}$.

A Lei 11.196/2005 tratou da prestação de serviços intelectuais por meio

${ }^{289}$ TRT $2^{\text {a }}$ REGIÃO, PROCESSO No: 01373-2007-261-02-00-8, RELATOR(A): REGINA MARIA VASCONCELOS DUBUGRAS, DATA DE PUBLICAÇÃO: 12/08/2010. Disponível em http://www.trt2.jus.br/pesquisa-jurisprudencia-por-palavra-acordaos . Acesso 30.10.2013.

Neste mesmo sentido, vale a transcrição da seguinte ementa: EMENTA: Prestação de serviços por pessoa jurídica. Possibilidade. É possível a prestação de serviços por pessoa jurídica a outra empresa desde que não estejam presentes os requisitos dos artigos $2^{\circ}$ e $3^{\circ}$ da CLT e não exista fraude. (TRT 2 ${ }^{\mathrm{a}}$ REGIÃO, PROCESSO No: 01983-2005-030-02-00-5, RELATOR(A): SERGIO PINTO MARTINS, DATA DE PUBLICAÇÃO: 12/06/2007 ).

290 SILVA, Otavio Pinto e. A função do Direito do Trabalho no mundo atual. In CORREIA, Marcus Orione Gonçalves (organizador). Curso de Direito do Trabalho - Teoria Geral do Direito do Trabalho. Volume I. Ltr, 2007-2008, p. 151-152.

291 Os novos contornos das relações de trabalho e de emprego - Direito do Trabalho e a nova competência trabalhista estabelecido pela Emenda 45/04. In Revista Ltr, vol.69, nº5, maio de 2005, p. 564. 
de pessoa jurídica visando proporcionar segurança jurídica, assumindo uma preocupação notadamente tributária. Não se pode dizer que referida legislação visou proporcionar uma fuga ao Direito do Trabalho, já que, conforme dito, tais prestadores de serviços são trabalhadores autônomos ou parassubordinados.

O que se considera, neste momento, à luz de todo o estudo já desenvolvido, é que o Direito do Trabalho poderia abarcar tais situações se houvesse uma regulamentação do trabalho parassubordinado, que fixasse tutelas mínimas a serem a ele aplicadas. Em outras palavras, este ramo do Direito poderia aumentar seu campo de atuação ao regulamentar o trabalho parassubordinado, que, então, seria prestado sem a necessidade de constituição de pessoa jurídica. Esta regulamentação seria um novo instrumento de que se utilizaria o Direito do Trabalho para tentar garantir a todos os cidadãos o acesso ao trabalho decente, já que o grande desafio que se coloca a este ramo do Direito, na atualidade, é, nas palavras de Otavio Pinto e Silva, promover as relações de trabalho e proteger os trabalhadores ${ }^{292}$.

Por fim, não se nega que o recurso à constituição de uma pessoa jurídica é, muitas vezes, utilizado como expediente para afastar a aplicação da legislação trabalhista camuflando uma relação de emprego, conduta esta que não pode ser aceita pelo ordenamento e pelos operadores do direito. Uma vez verificada que esta prática encobre uma relação de emprego, esta deve ser reconhecida em homenagem ao princípio da primazia da realidade, conforme será abaixo analisado.

292 A função do Direito do Trabalho no mundo atual. In CORREIA, Marcus Orione Gonçalves (organizador). Curso de Direito do Trabalho - Teoria Geral do Direito do Trabalho. Volume I. Ltr, 2007-2008, p. 154. 


\section{CAPÍTULO 4 - DA FRAUDE}

\subsection{Considerações gerais.}

Derivada do latim fraus, fraudis, a fraude é entendida, geralmente, como o engano malicioso ou a ação astuciosa promovidos pela má-fé visando a ocultação da verdade ou a fuga ao cumprimento de um dever ${ }^{293}$. Pode ser definida como uma manobra enganosa mediante a qual se pretende elidir uma proibição legal ou causar um dano a terceiros (ou mesmo se pretende alcançar os dois propósitos ao mesmo tempo) realizando um ato jurídico real, em princípio lícito, que a encobre ${ }^{294}$.

Desde tempos imemoriáveis, os homens, impulsionados por seu egoísmo e pela busca de proventos, ferem os direitos e interesses de terceiros através de processos ardilosos. O defraudador não é apenas desleal e desonesto, mas inteligente e astuto no emprego de procedimentos para a frustração da lei. O ato realizado, em sua constituição, é válido, mas na sua destinação ou orientação de obter o resultado planejado, viola a lei. A fraude é a própria negação do direito, contrapondo-se a todas as regras jurídicas (fraus omnia corrumpit) $)^{295}$.

Tratando-se de uma forma de agir sutil, a fraude é mais frequente nos países mais desenvolvidos culturalmente, evidenciando que o progresso da humanidade se faz pela substituição de hábitos violentos pelas praxes astuciosas, fruto de uma inteligência preordenada à ilicitude ${ }^{296}$. Por outro lado, aponta-se que a violência, normalmente utilizada como um meio rápido e instintivo de se alcançar um resultado, é mais presente nas sociedades menos desenvolvidas ${ }^{297}$.

Em seu estudo, destaca-se o princípio da boa fé, que se revela como o

${ }^{293}$ SILVA, De Plácido e. Vocabulário Jurídico. $15^{\mathrm{a}}$ edição. Rio de Janeiro, 1998, p. 370.

294 POSE, Carlos. Fraude y simulación em el derecho laboral. $1^{\mathrm{a}}$ ed. Buenos Aires: David Grinberg Libros Jurídicos, 2007, p. 14.

295 LIMA, Alvino. A fraude no direito civil. São Paulo: Saraiva, 1965, p. 01-03 e 20-23.

296 JUNIOR, Humberto Theodoro. Fraude contra credores: a natureza da sentença pauliana. $2^{\mathrm{a}}$ ed., rev. Atual. Ampl. Belo Horizonte: Del Rey, 2001, p. 60-62.

297 BARBATO, Maria Rosaria. La frode alla legge nel diritto del lavoro italiano e brasiliano. Dottorato di ricerca in autonomia individuale e autonomia colletiva, Universitá Degli Studi di Roma "Tor Vergata", 2008/2009, p. 15. Disponível em http://dspace.uniroma2.it/dspace/bitstream/2108/1063/1/Tesi.pdf. Acesso 25.03.2013. 
meio através do qual a Moral penetra no Direito. A sua aplicação visa proteger aqueles que agem lealmente, com probidade ou na ignorância excusável das situações antijurídicas. Trata-se de regra fundamental das relações humanas, eis que nas múltiplas relações obrigacionais há um dever de uma conduta leal, gerador da confiança entre as partes e pressuposto imprescindível para a vida em sociedade ${ }^{298}$.

A análise da boa fé abrange dois aspectos. Pelo aspecto subjetivo, supõe uma qualidade da vontade que, segundo a concepção romana, é entendida como um sentimento íntimo de lealdade, honestidade e justiça da própria conduta. Em sua manifestação objetiva, constitui um modelo de conduta à qual ordinariamente "o bom pai de família" ou "o homem bom" ajusta sua atuação. Neste sentido, não é uma mera qualidade da vontade que serve para ajustar ou excluir as responsabilidades dos atos humanos, mas um princípio normativo (um "standard jurídico") do qual derivam determinadas obrigações que devem ser respeitadas ainda que não deduzidas expressamente da lei ou do contrato ${ }^{299}$.

A boa-fé, assim, é, essencialmente, uma atitude de cooperação, destinada a atender de modo positivo à expectativa de outra parte. $\mathrm{O}$ dolo, a fraude, a simulação fraudulenta representam a negação desta boa-fé ${ }^{300}$.

A fraude corresponde a um vício de muitas faces e, qualquer que seja a sua forma, atenta contra o Direito. Assim, o ordenamento jurídico, em todos os seus ramos, se insurge contra este procedimento ardiloso, tanto no âmbito do direito privado como no público, visando assegurar a eficácia das normas jurídicas.

Exemplificativamente, o Direito Civil combate a fraude contra credores (arts. 158 a 165, do CC) e considera nulo o negócio jurídico quando tiver por objetivo fraudar lei imperativa (art. 166, do CC); o Direito Penal combate os crimes cometidos por meio da fraude (artigos 171 a 179, do Código Penal que versam sobre estelionato, fraude no comércio, fraude à execução, etc), o Direito Processual Civil considera litigante de máfé aquele que altera a verdade dos fatos, usa do processo para obter objetivo ilegal e procede de modo temerário (artigo 17, do CPC), combate a fraude à execução (artigo 593,

298 LIMA, Alvino. Op. cit., p. 10-11.

299 HERRERO NIETO, Bernardino. La simulación y el fraude a la ley em el derecho del trabajo. Bosch. Barcelona: Casa Editorial, 1958, p. 239-240.

300 CAHALI, YUSSEF SAID. Fraude contra credores, fraude à execução, ação revocatória falencial, fraude à execução fiscal, fraude à execução penal. 2a ${ }^{a}$. ed. São Paulo: Editora Revista dos Tribunais, 1999, p. 50-52. 
do CPC), o Direito Tributário prevê a possibilidade de a autoridade administrativa desconsiderar atos ou negócios jurídicos praticados com a finalidade de dissimular a ocorrência do fato gerador do tributo ou a natureza dos elementos constitutivos da obrigação tributária (artigo116, parágrafo único, CTN), o Direito do Trabalho dispõe que "serão nulos de pleno direito os atos praticados com o objetivo de desvirtuar, impedir ou fraudar a aplicação dos preceitos contidos na presente Consolidação" (artigo 9 ${ }^{\circ}$, da CLT).

No campo do Direito do Trabalho, muitas vezes se verificam práticas que encobrem um vínculo de emprego mediante contratação fraudulenta por meio de cooperativa, de pessoa jurídica ou de estagiário, pela terceirização ilícita, pela oferta de ações da empresa aos próprios empregados (stock options), entre outros mecanismos. Trata-se de formas de precarização do contrato de trabalho, cujo objetivo é reduzir custos burlando a legislação trabalhista.

A fraude, portanto, surge como um meio insidioso, realizada com a finalidade de obtenção de vantagens a qualquer preço. Embora esteja presente em todos setores da atividade humana, quando praticada no âmbito das relações trabalhistas, além de ferir a dignidade da pessoa humana nos termos propostos pela Constituição Federal, constitui óbice à criação de novos postos regulares de trabalho, prejudicando o aprimoramento daqueles já existentes, além de agir em detrimento do real valor do trabalho 301.

O principal objetivo deste Capítulo é o estudo da constituição de pessoa jurídica pelo empregado como forma de burlar a relação de emprego, prática que se mostra bastante difundida no mercado de trabalho. A análise desta questão específica, entretanto, será precedida de um estudo mais amplo sobre a fraude no âmbito civil e sua distinção em relação a outros institutos jurídicos, bem como da análise do tratamento da fraude pelo Direito do Trabalho.

\subsection{Da fraude à lei.}

O problema da fraude à lei é antigo e as primeiras referências sólidas à

\footnotetext{
301 SILVA, Wilma Nogueira de Araújo Vaz da. Comentários sobre algumas das fraudes recorrentes nas
} relações do trabalho. In Revista do Tribunal Regional do Trabalho da $2^{a}$ Região, n. 03, 2009, p.71. 
figura remontam ao direito romano, sobretudo a partir do período clássico ${ }^{302}$, embora ausente uma teoria geral sobre o tema ${ }^{303}$. Na realidade, a concepção romana tradicional da fraude pressupunha a existência de uma contraposição entre a letra da lei (verba legis) e o espírito da lei (sententia legis), que corresponde à distinção entre interpretação gramatical e lógica. $\mathrm{Na}$ visão dos jurisconsultos romanos, portanto, o agir em fraude à lei é caracterizado pela violação ao espírito da lei, sendo que a tarefa do intérprete é alcançar a sententia legis, que prevalece sobre sua letra em caso de eventual conflito. Mas em qualquer caso, aos atos fraudulentos se aplicava a mesma norma que disciplinava a violação direta, uma vez que a fraude era considerada uma forma velada de violação à $1 \mathrm{ei}^{304}$.

Cada questão se reduzia a um problema de interpretação da lei e os jurisconsultos romanos pareciam claramente que se referiam à fraude à lei não como um instituto, mas como uma característica que fazia parte do modo de ser do sistema. Ou seja, um modo que não se limitava à letra, mas que levava em conta o espírito da lei ${ }^{305}$.

A definição da fraude como um procedimento oblíquo ou indireto custou muito trabalho à doutrina ${ }^{306}$ cujo problema de fundo era individuar uma interpretação que permitisse à fraude alcançar uma autonomia e originalidade no âmbito do ordenamento ${ }^{307}$. Afirma-se que os esforços para a concretização de uma fórmula geral sobre fraude à lei se concentraram nos séculos XIX e XX e ocorreram no âmbito do Direito Civil, destacandose as doutrinas italiana e germânica ${ }^{308}$.

De uma maneira geral, pode-se afirmar que sugiram duas teorias para o estudo da fraude à lei: a teoria objetiva e subjetiva.

A teoria objetiva privilegia o objeto material, ou seja, o resultado perseguido pelas partes no negócio, que deve se apresentar em perfeita coincidência com aquele proibido pela norma imperativa. A especificidade desta situação se dá,

\footnotetext{
${ }^{302} \mathrm{O}$ estudo do direito romano é dividido em períodos, de acordo com a sua evolução interna: período arcaico (da fundação de Roma, só século VIII a.C até o século II a.C), o período clássico (até o século III d.C) e o período pós clássico (até o século VI d. C) (Marky, Thomas. Op. cit., p. 5-6)

303 VICENTE, Joana Nunes. A fuga à relação de trabalho (típica) em torno da simulação e da fraude à lei. Coimbra editora, 2008, p. 33.

304 BARBATO, Maria Rosaria. Op. cit., p. 19-21.

${ }^{305}$ MORELLO, Umberto. Frode alla legge. Milano: Dott. A . Giuffrè Editore, 1969, p. 15.

${ }^{306}$ Ibidem, p. 20-21.

${ }^{307}$ BARBATO, Maria Rosaria. Op. cit., p. 27.

${ }^{308}$ VICENTE, Joana Nunes. Op. cit., p. 33.
} 
exclusivamente, pela circunstância de que a violação da lei é perpetrada de forma oculta. A crítica que se faz a este posicionamento é a de que, independentemente da forma como se alcança o resultado vetado, se está sempre diante de uma violação da lei. Há uma aproximação com os atos contra legem, reduzindo a problemática ora analisada à exata interpretação da lei. Ou seja, trata-se da mesma norma proibitiva que, de forma ponderada ou extensivamente interpretada, sanciona a invalidade de um negócio jurídico sem a necessidade de qualquer outra norma ${ }^{309}$.

Por outro lado, a teoria subjetiva destaca o elemento psíquico do negócio. Há uma mudança na forma de compreender a fraude de modo que o aspecto material do resultado perde importância, bastando que seja um resultado análogo ou parecido àquele proibido. $\mathrm{O}$ discurso se desenvolve em torno da vontade de burlar a proibição legal. Há um intento de fazer com que esta vontade se mostre conforme ao direito através de um aparente respeito à norma violada. As críticas tecidas à teoria subjetiva residem no fato de que ao se admitir que o objetivo das partes seja apenas parecido ou análogo àquele vetado, nenhuma sanção poderia ser aplicada ao caso concreto a não ser se aceite uma interpretação analógica de norma proibitiva, o que, geralmente, é rechaçado ${ }^{310}$. Além disso, a dificuldade desta teoria consiste na demonstração da intenção, o que a torna impraticável na maioria dos $\operatorname{casos}^{311}$.

Diante da insuficiência das duas teorias, estudos mais aprofundados começaram a ser desenvolvidos visando superar os estreitos limites em que a questão era posta. Umberto Morello parte da pesquisa de alguns elementos de natureza objetiva emergentes da situação econômica e de interesses envolvidos no caso concreto para traçar um processo de racionalização da técnica da fraude à lei. Sua obra se fundamenta no exame de casos práticos e nas regras de decisão, obtendo uma construção unitária, mais condizente à realidade ${ }^{312}$. Segundo referido autor, o problema da fraude à lei surge nas situações em que, por razões de oportunidade ou por razões técnicas, uma interpretação ampla da norma ou uma reconstrução ampla do esquema negocial não se revela possível. Além disso, pode envolver quaisquer tipo de normas (e não somente as normas

\footnotetext{
309 PUGLIESE, Antonio. Riflessioni sul negozio in forde alla legge. In Rivista del Diritto Commerciale e del Diritto Generale delle obligazioni. Padova, v. 88, n. 3-4, mar/apr 1990, anno LXXXVIII, p. 161-162.

310 Ibidem, p. 162-163.

311 HERRERO NIETO. Bernardino. Op. cit., p. 302.

312 PUGLIESE, Antonio. Op. cit., p. 163-165.
} 
imperativas), desde que tidas como desfavoráveis pelos particulares a e cujo âmbito de aplicação pretendem se furtar ${ }^{313}$.

Antonio Pugliese coloca que a substancial mudança na forma de conceber a fraude à lei é atribuída a Pugliatti, que rompe com a uniformidade do debate doutrinário. Referido autor, enquanto afirma a necessidade de identidade do resultado perseguido com aquele vetado, coloca, no plano autônomo da estrutura, a distinção entre o negócio em fraude e o negócio contra a lei. A construção monolítica do negócio fraudatório cede espaço para uma particular hipótese de conexão negocial. Esta teoria é retomada pela doutrina mais recente que define sinteticamente a fraude como uma combinação de atos que em si mesmos são lícitos, mas que em seu conjunto revelam uma função ilícita. Para este posicionamento mais recente, se mostra mais condizente à realidade referir-se a um procedimento fraudulento no lugar da tradicional expressão negócio in fraudem legis ${ }^{314}$.

Giuseppe Criscenti coloca que a fraude à lei se distingue das hipóteses de direta contrariedade se entendida como um fenômeno relacionado a uma pluralidade de atos. Isto não significa que um ato singular não possa conter uma finalidade elusiva ou não possa visar subtrair as partes de uma norma desfavorável, mas, nestes casos, ou o contrato é simulado ou a operação praticada pode ser corretamente interpretada ou qualificada. Quase sempre, a realização de um intento fraudulento é confiada a um complexo de operações interligadas do que a um ato negocial ${ }^{315}$.

Bernardino Herrero Nieto coloca que a configuração da fraude à lei não pode ser reduzida a um só termo, qual seja, a intenção ou o resultado alcançado. A grande questão é a forma como se concretiza esta intenção. Em matéria de fraude, esta forma consiste na arte desleal de depreciar as leis com a aparência de submeter-se a elas. É, em suma, um conjunto de meios oblíquos empregados com o fim de conseguir o resultado que a lei queria proibir, conformando sua conduta de tal modo que sua reprovação não se faça diretamente ${ }^{316}$.

O estudo sobre as diversas teorias doutrinárias desenvolvidas a respeito da fraude à lei não será aprofundado a fim de se evitar o desvio dos objetivos do presente trabalho. No entanto, estas breves considerações se mostram relevantes para a análise de

313 VICENTE, Joana Nunes. Op. cit., p. 52-55.

314 Op. cit., p. 165.

315 I contratti in forde alla legge. Seconda Edizione. Milano: Giufrrè editore, 2008, p. 42.

316 HERRERO NIETO, Bernardino. Op. cit., p. 303. 
alguns dispositivos legais.

O Código Civil italiano de 1942, em seu art. 1344, ao se referir ao contrato em fraude à lei dispõe que se reputa também ilícita a causa quando o contrato constitui o meio para iludir a aplicação de uma norma imperativa ${ }^{317}$.

Joana Nunes Vicente coloca que a abordagem da fraude à lei, sob a perspectiva da causa do negócio jurídico, se faz no âmbito do ordenamento jurídico italiano, em que o legislador autonomizou a causa como um dos elementos do negócio jurídico dotado de interesse prático e relevância jurídica. A questão da fraude, consequentemente, é estudada sob coordenadas específicas ${ }^{318}$.

Não obstante a referência do dispositivo ao âmbito contratual, deve-se notar que a noção de fraude à lei foi desenvolvida tendo em vista também outros setores do direito, razão pela qual é considerada uma categoria geral ${ }^{319}$. Trata-se, portanto, de uma norma geral que impõe ao intérprete a difícil tarefa de definir seu conteúdo e limite diante da referência à "causa" do contrato, conceito sobre o qual não há um entendimento unânime na doutrina italiana ${ }^{320}$.

Embora o art. 1344, do Código Civil italiano não fixe uma sanção específica aos atos em fraude à lei, a doutrina majoritária entende que deve ser reconhecida a nulidade pela ilicitude da causa. Isto porque o artigo em estudo considera ilícita a causa do contrato realizado para burlar a aplicação da lei imperativa e o art. 1418, §2 $2^{\circ}$, do mesmo

\footnotetext{
${ }^{317}$ Art. 1344: Contratto in frode alla legge: Si reputa altresì illecita la causa quando il contratto costituisce il mezzo per eludere l'applicazione di una norma imperativa. Disponível em http://www.jus.unitn.it/cardozo/obiter dictum/codciv/Lib4.htm, acesso 28.03.2013. Tradução livre.

Referido dispositivo encontra-se no Livro Quarto, relativo às obrigações, na Seção II ("Da causa do contrato), do Capítulo II ("Dos requisitos do contrato"), do Título II ("Dos Contratos em Geral").

318 Op. cit., p. 35.

319 GESTRI, Marco. Abuso del dirittto e frode alla legge nell'ordinamento comunitario. Milano: Giuffrè, Fott. A . Giufrrè Editore, 2003, p. 51

320 BARBATO, Maria Rosaria. Op. cit., p. 39.
} 
Código $^{321}$ impõe a nulidade à ilicitude da causa ${ }^{322}$.

Relacionado ao Direito Internacional Privado, o Código Civil de Portugal (Decreto Lei 47.344, de 25 de novembro de 1966) traz, em seu artigo 21, referente à fraude à lei, a seguinte disposição: "Na aplicação das normas de conflitos são irrelevantes as situações de fato ou de direito criadas com o intuito fraudulento de evitar a aplicabilidade da lei que, noutras circunstâncias, seria competente". Assim, na aplicação das normas em conflito, não se devem considerar as situações de fato ou de direito criadas com a intenção fraudulenta de evitar a aplicação da lei competente. A doutrina portuguesa vê, nesta disposição, a aplicação da teoria geral da fraude à lei que assume características particulares no direito internacional privado ${ }^{323}$.

Apesar da referência à fraude à lei no Direito Internacional Privado, não há no Código Civil português outra disposição a respeito. Joana Nunes Vicente coloca que a generalidade da doutrina portuguesa se orienta convictamente em direção à não autonomização da figura da fraude à lei como categoria jurídica com uma estrutura e disciplina próprias. A falta de espaço para uma teoria autônoma sobre a fraude à lei decorre da constatação de que o problema se circunscreve em uma interpretação da norma iludida e na fixação de seu âmbito de aplicação. A violação da lei existe quer quando se contraria sua letra diretamente, quer quando se viola seu espírito. Consequentemente, se mostra desnecessária uma sanção jurídica específica para os negócios concretizados em fraude à $1 \mathrm{ei}^{324}$.

No Direito espanhol, o $\S 4^{\circ}$, do art. $6^{\circ}$, localizado no Capítulo III (“Eficacia general de las normas jurídicas”), do Título Preliminar, do Código Civil dispõe:

${ }^{321}$ Art. 1418 Cause di nullità del contratto:

Il contratto è nullo quando è contrario a norme imperative, salvo che la legge disponga diversamente.

Producono nullità del contratto la mancanza di uno dei requisiti indicati dall'art. 1325, l'illiceità della causa (1343), l'illiceità dei motivi nel caso indicato dall'art. 1345 e la mancanza nell'oggetto dei requisiti stabiliti dall'art. 1346.

Il contratto è altresì nullo negli altri casi stabiliti dalla legge (190, 226, 458, 778 e seguente, 780 e seguente, 788, 794, 1261, 1344 e seguente, 1350, 1471, 1472, 1895, 1904, 1972).

(Disponível em http://www.jus.unitn.it/cardozo/obiter dictum/codciv/Lib4.htm, acesso 04.04.2013).

322 BARBATO, Maria Rosaria. Op. cit., p. 40

323 GESTRI, Marco. Op. cit., p. 31.

324 Op. cit., p. 41-46. Segundo a autora, este mesmo posicionamento da doutrina portuguesa é acompanhado pela doutrina germânica. 
"os atos realizados ao amparo do texto de uma norma que persigam um resultado proibido pelo ordenamento jurídico, ou contrário a ele, se considerarão executados em fraude à lei e não impedirão a devida aplicação da norma que se pretendeu iludir" ${ }^{\prime 325}$.

Observa-se, inicialmente, que no Código Civil espanhol, a técnica da fraude é tratada como um instituto de aplicação geral, em razão da referência genérica ao termos "atos" no início da disposição. Ou seja, o instituto não se circunscreve ao âmbito contratual. Por outro lado, da leitura do texto legal não parece que se exija que o ato fraudulento persiga um objetivo vetado por uma norma específica, podendo contrariar os princípios e as finalidades gerais do ordenamento jurídico. Controvertida é a relevância do elemento intencional para a integração da fraude. No campo doutrinário, se em época recente parecia prevalente a tese objetiva, não faltam autores a defender posicionamento diverso. A sanção, nos termos do artigo analisado, consiste na submissão do ato fraudulento ao império da lei que se tentou burlar ${ }^{326}$.

Ainda no Direito espanhol e especificamente voltado ao direito internacional privado, o art. $12, \S 4^{\circ}$, do Capítulo IV ("Normas de Derecho Internacional Privado"), dispõe que se considerará fraude à lei a utilização de uma norma de conflito com o fim de eludir uma lei imperativa espanhola ${ }^{327}$. Este dispositivo é considerado como uma particular aplicação ao campo do direito internacional privado da categoria geral da fraude à lei. Referido artigo se omite quanto à sanção a ser aplicada, que se resolve com a incidência da previsão do art. $6^{\circ}, \S 4^{\circ}$. Considerando que o art. $12, \S 4^{\circ}$ se refere ao "fim de eludir uma lei”, prevalece, neste campo específico, a noção subjetivista da fraude ${ }^{328}$.

No ordenamento jurídico brasileiro, o Código Civil de 1916 não possuía dispositivo genérico que disciplinasse a fraude à lei. Seguindo a influência do Direito francês, somente a fraude contra credores recebia regramento ${ }^{329}$. O Código Civil de 2002, em seu art. 166, inc. VI, considera nulo o negócio jurídico quando tiver por objeto fraudar

\footnotetext{
${ }^{325}$ Tradução da autora. Texto original: Los actos realizados al amparo del texto de una norma que persigan un resultado prohibido por el ordenamiento jurídico, o contrario a él, se considerarán ejecutados en fraude de ley y no impedirán la debida aplicación de la norma que se hubiere tratado de eludir. Disponível em http://civil.udg.es/normacivil/estatal/cc/tprel.htm . Acesso 02.04.2013.

326 GESTRI, Marco. Op. cit., p. 35-36.

327 Tradução da autora. Texto original: Se considerará como fraude de ley la utilización de una norma de conflicto con el fin de eludir una ley imperativa española.. Disponível em http://civil.udg.es/normacivil/estatal/cc/tprel.htm . Acesso 02.04.2013

328 GESTRI, Marco. Op. cit., p. 37-38.

${ }^{229}$ PEREIRA, Regis Fichtner. Fraude à lei. Rio de Janeiro: Renovar, 1994, p. 102. LIMA, Alvino. Op. cit., p. 03.
} 
lei imperativa.

No entanto, o que se observa é que não há uma teoria geral da fraude que abranja todos os aspectos ou modalidades dos atos fraudulentos ${ }^{330}$.

A doutrina enumera duas formas de fraude: fraude à lei e a fraude contra terceiros. Na fraude à lei, verifica-se a frustração da lei imperativa ou proibitiva, sem que seus autores tenham por fim imediato ou mediato atingir direitos de terceiros, o que pode, excepcionalmente, ocorrer. Já na fraude contra o direito de terceiros, além da frustração da lei, a ação do autor do ato fraudulento se dirige sempre intencionalmente ou com consciência da lesão do direito, contra o titular do mesmo direito lesado. Esta última modalidade de fraude é subdividida em fraude contra direitos de terceiros ou contra a transferência de direitos e a fraude pauliana ${ }^{331}$.

A fraude que atinge direitos de terceiros não decorre da insolvabilidade do devedor, mas envolve a prática de atos fraudulentos que extinguem os efeitos jurídicos dos atos anteriores impedindo que o primeiro titular de um direito possa fazer prevalecer os efeitos da convenção anterior ${ }^{332}$.

Para Alvino Lima, em todo ato em fraude aos credores, em sentido amplo, ou em fraude à lei, em sentido estrito, dois elementos essenciais e comuns se destacam: a) a prática de um ato jurídico absolutamente perfeito e legal, considerado em si mesmo; b) a frustração ou violação indireta, encoberta, intencional ou consciente de uma norma imperativa. No entanto, na fraude pauliana e na fraude contra as transferências de direitos, mais dois elementos se apresentam: o dano ocasionado ao credor ou ao titular de um direito sendo que, no caso da fraude pauliana, o dano decorre da insolvabilidade do devedor; e a necessária participação de terceiros na frustração da norma jurídica ${ }^{333}$.

\subsection{Distinções entre fraude e demais vícios do negócio jurídico.}

A fraude, como referido acima, pode ser definida como engano, porém, pondera-se que nem todo engano pode caracterizar uma fraude, já que existem figuras afins

\footnotetext{
330 LIMA, Alvino. Op. cit., p. 19.

331 Ibidem, p. 04-12.

332 Ibidem, p. 21.

333 Op. cit., p. 20-25.
} 
como o dolo e a simulação. Na fraude, o negócio é efetivo e real. Viola-se o espírito da lei, pois se utiliza uma norma para alcançar um resultado proibido pela outra. Márcio Túlio Viana traz o seguinte exemplo: "a CLT permite que o empregador remova o empregado de uma filial para outra, na mesma localidade. Sabendo disso, A desloca B para junto de seu inimigo C, para levá-lo a se demitir ${ }^{, 334}$.

Por dolo entende-se o artifício ou expediente astucioso empregado para induzir ou manter alguém erro, viciando a vontade do destinatário. Surge concomitantemente ao negócio. A doutrina destaca os seguintes requisitos necessários à sua configuração: a) intenção de induzir o declarante a praticar o ato jurídico; b) a utilização de recursos fraudulentos graves; c) os artifícios utilizados são a causa determinante da declaração de vontade; d) que a astúcia proceda de outro contratante ou seja por este conhecida como procedente de terceiros. Portanto, o dolo deve ser essencial,ou seja, a razão da vontade do declarante, e deve conter a intenção de prejudicar. O dolo principal ou essencial caracteriza vício de consentimento tornando o ato jurídico anulável. O dolo acidental só obriga ao pagamento de perdas e danos, já que, neste caso, o dolo não é a razão essencial para a realização do negócio jurídico ${ }^{335}$.

Como exemplo, cita-se o caso em que um empregador pensa em contratar determinado empregado e, para isso, acaba forjando dados irreais sobre as finanças de empresa ${ }^{336}$.

Simular é fingir, mascarar, camuflar, esconder a realidade. Caracteriza-se pelo intencional desacordo entre a vontade interna e a declarada, na medida em que se cria, aparentemente, um ato jurídico que oculta o realmente desejado. Há, portanto, um conluio entre os contratantes para proporcionar aparência exterior do negócio jurídico. Trata-se de um vício social ${ }^{337}$, em que as partes em geral pretendem criar na mente de terceiros falsa visão do pretendido. Apresenta, como elementos caraterísticos: a) em regra, é declaração bilateral de vontade; b) é sempre concertada com a outra parte ou com as pessoas a quem

\footnotetext{
334 VIANA, Márcio Túlio. Fraude à lei em tempos de crise. In Revista do Tribunal Regional do Trabalho da $9^{a}$ Região, Curitiba, v 21, n. 2, jul/dez 1996, p. 62.

${ }^{335}$ VENOSA, SILVIO DE SALVO. Direito Civil: parte gera., $3^{\text {a }}$. ed., São Paulo: Atlas, 2003, p. 441-445.

336 VIANA, Márcio Tulio. Fraude à lei em tempos de crise. In Revista do Tribunal Regional do Trabalho da $9^{a}$ Região, Curitiba, v 21, n. 2, jul/dez 1996, p. 63.

337 O Código Civil de 2002 prevê a nulidade do negócio jurídico simulado em seu artigo 167, subsistindo o ato dissimulado se válido na substância e na forma. Referido dispositivo está inserido não no Capítulo referente aos defeitos do negócio jurídico (Capítulo IV, Título I, Livro III), mas no que concerne à invalidade de tais negócios (Capítulo V, Título I, Livro III).
} 
ela se destina; c) não corresponde à intenção das partes; d) é realizada com o objetivo de iludir terceiros. A doutrina chama de simulação absoluta a situação em que a declaração de vontade exprime aparentemente um ato jurídico, não sendo intenção das partes efetuar ato algum. Por outro lado, é relativa a simulação quando há, efetivamente, a intenção de realizar um ato jurídico, mas este é de natureza diversa daquele que se declara, ou não é efetuado entre as próprias partes, aparecendo o testa de ferro, o prestanome, ou não contém elementos verdadeiros, ou melhor, seus dados são inexatos ${ }^{338}$.

A simulação muitas vezes é reconhecida nas situações em que um contrato de trabalho é utilizado como negócio aparente visando ocultar outro (ou mesmo nenhum outro) a fim de se obter benefício junto à Previdência Social ou prestações sociais por desemprego ${ }^{339}$.

O artigo 110, do Código Civil dispõe que "a manifestação de vontade subsiste ainda que o seu autor haja feito a reserva mental de não querer o que manifestou, salvo se dela o destinatário tinha conhecimento". A reserva mental ou reticência ocorre quando um dos declarantes oculta a sua real intenção não desejando o efeito jurídico que declara querer. Com a intenção de enganar o declaratário, emite-se uma declaração que diverge da vontade real. Essa mentira só será considerada relevante se acarretar efeitos jurídicos e, neste caso, o negócio não é invalidado pela reserva mental salvo se de conhecimento da outra parte. Isto porque a estabilidade das relações sociais não podem ficar expostas ao subjetivismo do declarante. O que caracteriza a reserva mental é a convicção do declarante de que o declaratário desconhece a mentira. No entanto, caso este tenha ciência da divergência, a situação muito se assemelha à simulação, tanto que parte da doutrina equipara os dois institutos ${ }^{340}$.

Importante tecer algumas considerações específicas sobre a fraude contra credores. Vista como vício social, a fraude contra credores, prevista nos artigos 158 a 165, do Código Civil, ocorre nas situações em que o devedor, insolvente ou na iminência de o ser, pratica atos de diminuição de seu patrimônio reduzindo, deste modo, a garantia que este representa para o resgate de suas dívidas. Trata-se, portanto, da diminuição maliciosa

338 VENOSA, SILVIO DE SALVO. Op cit., pp. 465-473. MONTEIRO, Washington de Barros. Curso de direito civil, parte geral. $35^{\text {a }}$ ed. São Paulo: Saraiva, 1997, p. 213-217.

339 VICENTE, Joana Nunes. Op. cit., p. 68-69.

340 VENOSA, Silvio de Salvo. Op. cit., p. 477-480. 
do lado ativo do patrimônio com a finalidade de macular os direitos creditórios ${ }^{341}$.

A legislação indica os atos através dos quais a fraude se concretiza: a) atos de transmissão gratuita e bens ou remissão de dívida; b) atos a título oneroso; c) pagamento antecipado de dívidas vincendas; d) constituição de direito de preferência a um ou alguns dos credores quirografários.

A revogação deste ato fraudulento, através da ação pauliana, depende da demonstração do eventus damni, do consilium fraudis e da anterioridade do crédito. Para a caracterização do consilium fraudis não se exige, do devedor, um propósito direto de prejudicar credores, ou seja, uma vontade deliberada de desfalcar seu patrimônio e tornarse insolvente (animus nocendi). Basta que o devedor tenha consciência de que o ato praticado levará à sua insolvabilidade ou a agravará, se esta for preexistente. Trabalha-se, portanto, com o dolo civil, que é o simples conhecimento do efeito lesivo do ato (scientia damni) e não a verdadeira e própria intenção de prejudicar os credores. Assim, cabe àquele que se vale da ação pauliana demonstrar que o devedor conhecia, no momento em que o ato foi praticado, a sua insolvência ou que o ato a criava ${ }^{342}$.

A legislação dispensa tratamento diferenciado nos atos a título gratuito e nos atos onerosos. Em relação aos primeiros (atos a título gratuito), a fraude está in re ipsa pelo próprio fato de o devedor ser reduzido à insolvência, não sendo investigado qualquer elemento subjetivo. Ou seja, não se exige a demonstração de que o devedor ou terceiro beneficiário da gratuidade tivesse ou devesse ter conhecimento do desfalque causado ao patrimônio. Já nos contratos onerosos, pelo fato de estes acarretarem direitos e deveres a ambas as partes, deve ser demonstrada a fraude bilateral, ou seja, a coparticipação do adquirente do ato viciado, o seu conhecimento da insolvência (scientia fraudis). Exige-se, assim, do participes fraudis o real ou presumível conhecimento acerca da insolvência do devedor e do resultado que o ato ou contrato pode provocar aos credores deste. Não se cogita da intenção de causar prejuízo. Isto porque, se o terceiro estiver de boa fé, a sua situação irá se assemelhar à do credor lesado sendo preferível a proteção do primeiro pois, nas palavras de Yussef Said Cahali, in pari causa melio est condicio possidentis (in pari causa possessor potior haberi debet) ${ }^{343}$.

${ }^{341}$ RODRIGUES, SILVIO. Direito Civil. Parte Geral. V.1. $27^{\mathrm{a}}$ ed. Saraiva, 1997 p. 228. PEREIRA, Caio Mario da Silva. Instituições do Direito Civil. Vol. 1. $2^{\mathrm{a}}$ ed. Rio de Janeiro: Forense, 1991, p. 372.

${ }^{342}$ CAHALI, Yussef Said. Op. cit., p. 214-221.

${ }^{343}$ Op. cit., p. 224-231. 


\subsection{Fraude no Direito do Trabalho.}

As fraudes são comuns no campo trabalhista, uma vez que neste ramo do Direito a lei constrange o empregador. Por outro lado, o empregado é constrangido por suas necessidades. Além disso, as mudanças no modo de produção promovidas pela globalização fomentam a multiplicação destes mecanismos $\operatorname{ardilosos}^{344}$.

O princípio da boa fé anteriormente analisado ganha relevância neste estudo. A relação trabalhista está entre as convenções em que a lei exige a mais completa boa fé para a sua formação, pois são nestes contratos, mais que em qualquer outro, que o homem é a medida de todas as coisas. Por ser a prestação de trabalho algo ligado, de maneira duradoura, à personalidade daquele que a realiza, se exige, tanto da parte que executa uma obra ou presta um serviço quanto da parte que os aceita, uma vontade não só consciente da juridicidade ou dos efeitos jurídicos do ato, mas também uma vontade essencial e primordialmente determinada pelo princípio da boa fé ${ }^{345}$.

Encontra-se, na doutrina, referência ao princípio da conduta laboral honesta, que consiste em uma condição importante e indispensável para que a relação jurídica laboral possa, plenamente, realizar, por um lado, seus objetivos econômicos patrimoniais e, de outro lado, seus deveres éticos ${ }^{346}$.

Neste sentido, anota-se que a Ley de Contrato de Trabajo da Argentina (Ley n ${ }^{\circ} 20.744$ - texto ordenado pelo Decreto390/76) dispõe, em seu artigo 63, que as partes estão obrigadas a trabalhar de boa fé, ajustando sua conduta ao que é próprio de um bom empregador e de um bom trabalhador, tanto ao celebrar, executar ou extinguir o contrato ou a relação de trabalho ${ }^{347}$.

Em outras palavras, trata-se de um princípio que deve ser considerado

\footnotetext{
344 VIANA, Márcio Tulio. Fraude à lei em tempos de crise. In Revista do Tribunal Regional do Trabalho da $9^{a}$ Região, Curitiba, v 21, n. 2, jul/dez 1996, p. 64.

345 HERRERO NIETO. Bernardino. Op. cit., p. 238-239.

346 Ibidem, p. 240-241.

347 Tradução da autora. Texto original: Art. 63. -Principio de la buena fe.

Las partes están obligadas a obrar de buena fe, ajustando su conducta a lo que es propio de un buen empleador y de un buen trabajador, tanto al celebrar, ejecutar o extinguir el contrato o la relación de trabajo. Disponível em http://infoleg.mecon.gov.ar/infolegInternet/anexos/25000-29999/25552/texact.htm , acesso 08.04.2013.
} 
para a aplicação de todos os direitos e obrigações que as partes adquirem em razão do contrato de trabalho ${ }^{348}$.

O Direito do Trabalho volta-se ao trabalhador como sujeito de direitos e como pessoa humana, colocando-se como instrumento de promoção dos direitos humanos de segunda geração ligados às relações de trabalho. Seu surgimento também está relacionado a uma necessidade política, ideológica e normativa visando a própria subsistência do sistema capitalista, que pode ser colocada em risco em face de uma exploração desenfreada do trabalho alheio. Se por um lado o Direito do Trabalho atua como um instrumento garantidor de justiça social e de direitos fundamentais, por outro, mostra-se como um limitador imposto pelo próprio sistema capitalista para a exploração da força de trabalho. Neste contexto, a fraude nas relações de trabalho é um instrumento de mercantilização do labor, consistente no emprego de métodos que conferem uma roupagem fictícia a uma relação de emprego, visando obstar, no todo ou em parte, a incidência da legislação trabalhista e a satisfação dos direitos sociais ${ }^{349}$.

A fraude laboral, do ponto de vista subjetivo, consiste na lesão causada à outra parte contratante e, do ponto de vista objetivo, considerando a dinâmica do ato, é movida pela ideia de lucro indevido ou proveito injusto, elementos que a caracterizam ${ }^{350}$. Pode abranger diversos aspectos materiais, quer em ralação ao empregado, quer em relação ao empregador e pode ocorrer no início, durante ou mesmo após a execução do contrato de trabalho ${ }^{351}$.

Inúmeros são os atos praticados por alguns empregadores com o objetivo de afastar a aplicação dos preceitos de ordem pública consagrados pelas leis de proteção ao trabalho. Arnaldo Süssekind coloca que a fraude nas relações de trabalho pode decorrer: a) de ato unilateral do empregador, ao se valer, maliciosamente, de um direito, com o escopo de impedir ou desvirtuar a aplicação de preceito jurídico de proteção ao seu empregado; b) por ato bilateral em virtude do qual o empregador e empregado simulam a existência de falsa relação jurídica entre ambos, a fim de ser ocultada a natureza do ato realmente ajustado. No caso da simulação, o próprio empregado concorda em disfarçar,

348 PLÁ RODRIGUES, Américo. Princípios de direito do trabalho. Tradução de Wagner D. Giglio. $3^{\mathrm{a}}$ ed., atual. São Paulo: Ltr, 2000, p. 428.

349 SANTOS, Ronaldo Lima dos. Op. cit., p. 89-91.

350 HERRERO NIETO, Bernardino. Op. cit., p. 282.

351 HUSEK, Carlos Roberto. A vontade contratual/vicios do consentimento/fraude. In Revista do Tribunal Regional do Trabalho da $2^{a}$ Região, n. 03, 2009, p. 81. 
maliciosamente, a verdadeira relação existente, seja por ignorância, seja por vício de consentimento decorrente da coação ${ }^{352}$.

Ao discorrer sobre a prestação de trabalho em condições de fraude ou simulação, Oscar Hernández Alvarez esclarece que as situações em que o empregador, a fim de burlar a legislação trabalhista, impõe ao trabalhador dependente a formalização de um contrato de natureza civil ou comercial, devem ser qualificadas como atos em fraude à lei. Embora alguns autores abordem este problema como simulação, não se pode dizer que existe uma vontade das partes para a realização de um ato simulado, ocultando a relação de trabalho, que corresponderia à verdadeira, mas confidencial, vontade das partes. $\mathrm{Na}$ verdade, trata-se de uma imposição de vontade de uma das partes, o empregador, que se vale de sua posição de superioridade em face da hipossuficiência econômica do trabalhador. A simulação, em matéria de trabalho, se relacionaria a outros aspectos em que as partes, de comum acordo, fazem determinadas declarações que não correspondem à realidade e que ocultam o ato simulado. Por exemplo, as partes declaram um salário diverso visando facilitar a obtenção de um crédito por parte do trabalhador ${ }^{353}$..

Carlos Pose cita os ensinamentos de Rubinstein para quem a fraude laboral se caracteriza quando alguma das partes da relação de trabalho, com ardil ou maquinação, encobre a verdadeira natureza jurídica do negócio, ou seja, encobre um contrato de trabalho. A fraude também se configura quando há a interposição de pessoas alheias à relação de trabalho para evitar a aplicação o cumprimento das obrigações contratuais e legais. De uma maneira geral, o fraudador é um sujeito que age dolosamente, isto é, emprega algum artifício, atua com astúcia com a intenção de burlar a lei trabalhista 354 .

Porém, esclarece referido autor que, para as leis trabalhistas a intencionalidade do agente é irrelevante para a caracterização da fraude ou da simulação, já que o ato será fraudulento simplesmente por se violar a ordem pública ${ }^{355}$.

Mesmo nos casos de simulação em que o empregado concorda em

\footnotetext{
${ }^{352}$ SÜSSEKIND, Arnaldo [et al.]. Op. cit., p. 226-227.

${ }^{353}$ HERNÁNDEZ ALVAREZ, Oscar. La prestación de trabajo em condiciones de fraude o simulación. [S.I]: [S.n], 1989. Texto obtido na biblioteca do Tribunal Regional do Trabalho da $2^{\mathrm{a}}$ Região.

${ }^{354}$ POSE, Carlos. Fraude y simulación em el derecho laboral. $1^{\text {a }}$ ed.. Buenos Aires: David Grinberg Libros Jurídicos, 2007, p. 15.

${ }^{355}$ POSE, Carlos. Op cit., p. 16.
} 
disfarçar a verdadeira relação existente, a sua participação não obsta o questionamento em juízo:

\begin{abstract}
"Em Direito do Trabalho, "governa-se o forte para se proteger o fraco". Dai por que, quase sempre, quem pratica a ilicitude é o empregador. Mas mesmo também quando o empregado dela participa, nada o impede de arguí-la. É o que se dá na simulação.

Assim, se o vendedor A celebra com B um contrato que o descreve como autônomo, pode provar o oposto em juizo. A simulação é inocente pra um e culposa para outro. Parte-se em duas a regra do direito civil”,356.
\end{abstract}

Considerando a hipossuficiência jurídica do empregado, a ocorrência da fraude no Direito do Trabalho prescinde da comprovação do consilium fraudis. Referido elemento subjetivo, exigido pelo Direito Civil para a demonstração da fraude contra credores, é afastado pelo Direito do Trabalho em que a fraude é objetiva. Neste sentido, destaca-se o disposto no artigo $9^{\circ}$, da CLT que dispõe: "serão nulos de pleno direito os atos praticados com o objetivo de desvirtuar, impedir ou fraudar a aplicação dos preceitos contidos na presente Consolidação"357.

A mesma previsão é encontrada no artigo 14, da Ley de Contrato de Trabajo da Argentina (Ley n ${ }^{\circ} 20.744$ - texto ordenado pelo Decreto390/76) que dispõe sobre a nulidade por fraude laboral:

"Artículo 14 - Será nulo todo contrato por el cual las partes hayan procedido con simulación o fraude a la ley laboral, sea aparentando normas contractuales no laborales, interposición de personas o de cualquier otro medio. En tal caso, la relación quedará regida por esta ley" ${ }^{358}$

\footnotetext{
356 VIANA, Márcio Tulio. Fraude à lei em tempos de crise. In Revista do Tribunal Regional do Trabalho da $9^{a}$ Região, Curitiba, v 21, n. 2, jul/dez 1996, p. 63

357 SANTOS, Ronaldo Lima dos. Op. cit., p. 91.

${ }_{358}$ Disponível em http://es.wikisource.org/wiki/Ley_de_Contrato_de_Trabajo_(Argentina)/TITULO_I_DISPOSICIONES GENERALES. Acesso 30.01.2013.
} 
A fraude objetiva no Direito do Trabalho é corolário do Princípio Contrato Realidade, eis que, presentes os requisitos da relação de emprego, esta é reconhecida independentemente da presença ou não do consilium fraudis entre as partes, do animus fraudandi do empregador ou da ciência ou consentimento do empregado em relação à contratação irregular ${ }^{359}$.

O contrato de trabalho é denominado contrato realidade, já que não existe em razão do acordo de vontade das partes, mas pela realidade da prestação do serviço. É esta que determina a proteção do Direito do Trabalho. Em sendo assim, a análise da situação de fato ganha relevo em relação à ficção jurídica, às aparências, ao nomen iuris dado pelas partes. Não se mostra necessário perquirir o grau de intencionalidade ou de responsabilidade de cada uma das partes, bastando verificar o que ocorre no campo dos fatos que, uma vez demonstrados, não podem ser afastados ou neutralizados por documentos ${ }^{360}$.

Referido princípio mostra-se como poderoso instrumento para a pesquisa e encontro da verdade real em uma situação de litígio trabalhista ${ }^{361}$. É mais que uma presunção: trata-se de um critério básico que estipula seja dada preferência aos fatos do que aos papéis ${ }^{362}$. Nas palavras de Arnaldo Süssekind, “a realidade objetiva evidenciada pelos fatos define a verdadeira relação jurídica estipulada pelos contratantes, ainda que sob capa simulada, não correspondente à realidade ${ }^{363 ", .}$

Portanto, para a aferição da fraude basta a presença material dos requisitos da relação de emprego, independentemente da roupagem jurídica conferida à prestação de serviços. É irrelevante para a configuração da relação de emprego a natureza do ato de ingresso do trabalhador na prestação de serviços, pois a identificação depende do modus operandi da prestação de serviço e não dos aspectos formais que a revestem. Até porque deve-se considerar que a fase de contratação é o momento de maior vulnerabilidade

\footnotetext{
359 SANTOS, Ronaldo Lima dos. Op. cit., p. 92

360 PLA RODRIGUES, Américo. Op. cit., p. 340-357.

361 DELGADO, Mauricio Godinho. Curso de direito do trabalho. 5a Ed., São Paulo: Ltr, 2006, p. $208-209$.

362 PLA RODRIGUES, Américo. Op. cit., p. 357.

363 SÜSSEKIND, Arnaldo [et al.]. Op. cit., p. 145
} 
do empregado e de sua autonomia de vontade ${ }^{364}$.

O estudo da fraude mostra-se relevante uma vez que tais práticas possuem transcendência social, econômica e política. A contratação de empregados por meios jurídicos fraudulentos não acarreta apenas a sonegação dos direitos trabalhistas, mas traz consequências à ordem jurídica social, na medida em que reduz a capacidade financeira do sistema de Seguridade Social, diminui os recolhimentos ao Fundo de Garantia do Tempo de Serviço, impossibilitando a utilização destes recursos em obras de habitação e infra estrutura, precariza as relações de trabalho, com prejuízo ao meio ambiente do trabalho, à integridade física e à saúde dos trabalhadores, acentua as desigualdades sociais e os problemas delas decorrentes, provoca aumento do número de demandas judiciais. Ressaltam-se as violações aos princípios e fundamentos da ordem econômica, uma vez que tais práticas fraudulentas prejudicam não só os trabalhadores explorados, mas, também, as demais empresas que observam a legislação trabalhista. A redução do valor do trabalho mostra-se como prática de concorrência desleal ${ }^{365}$.

Por outro lado, as práticas fraudulentas adotadas pelos empregadores visando uma redução de custos através da supressão de direitos trabalhistas prejudicam o próprio sistema capitalista, uma vez que trabalhadores desprovidos de boas condições sociais enfraquecem o mercado consumidor. Faz-se necessária uma conscientização dos benefícios que o Direito do Trabalho proporciona não apenas ao contratados, mas aos contratantes e a toda a sociedade ${ }^{366}$.

A fraude à relação de emprego apresenta uma configuração ampla e diversificada, sofisticando-se paralelamente à complexidade das próprias relações de trabalho e das novas formas de produção e expansão mercantil. Exemplificativamente, cita-se a utilização de formas de parceria, arrendamento, prestação de serviços autônomos, cooperado, contrato de sociedade, estagiário, representação comercial autônoma, entre outras $^{367}$.

\footnotetext{
${ }^{364}$ SANTOS, Ronaldo Lima dos. Op. cit., p. 92. STANDER, Celia Regina Camachi. Fraude por meio de cooperatativa e de constituição de pessoa jurídica por trabalhadores. In Revista da Escola da Magistratura do Tribunal Regional do Trabalho da $2^{a}$ Região, São Paulo, ano I, n. 1, setembro de 2006, p. 106. Disponível em http://www.trtsp.jus.br/html/tribunal/magistratura/pdfs/revistal.pdf. Acesso 25.04.2012.

${ }^{365}$ SANTOS, Ronaldo Lima dos. Op. cit., p. 101.

${ }^{366}$ VITORINO, Adriana. "CLT flex" - a nova modalidade de fraude. In Revista Ltr, ano 76, $\mathrm{n}^{\circ}$ 04, abril 2012, p. 465-468

${ }^{367}$ SANTOS, Ronaldo Lima dos. Op. cit., p. 92
} 
O presente trabalho se limitará a analisar uma destas formas, consistente na exigência de constituição de pessoa jurídica pelo trabalhador como requisito para o desenvolvimento da relação de emprego, fenômeno conhecido pelo neologismo "pejotização".

\subsection{Da fraude mediante contratação do trabalhador por meio de constituição de pessoa jurídica.}

Nesta parte do presente estudo, passa-se a analisar a questão da constituição de pessoa jurídica como um mecanismo para encobrir a relação empregatícia, ponderando, entretanto, que, embora exista uma tendência à práticas fraudulentas, esta não pode ser presumida, eis que também existem condutas lícitas de prestação de serviço autônomo ${ }^{368}$, conforme acima examinado.

A partir dos anos 90, inicia-se, no Brasil, um processo de reorganização do mercado de trabalho que se caracteriza pela ampliação de formas de contratação inseguras e desprovidas de proteção da legislação trabalhista. Com a superação do padrão de emprego fordista, assiste-se à emergência de múltiplas formas de contratação, muitas das quais representam uma burla ao sistema legal. Além do recurso à terceirização, aparecem as cooperativas de trabalho, o PJ e o trabalho estágio, formas que, muitas vezes, simulam a relação de emprego. Tais práticas são tidas como expressão da "nova informalidade" e o critério para definir tais contratações como informais é a relação de emprego disfarçada (encoberta ou simulada). Nestas situações, estão presentes as características do trabalho assalariado, mas a contratação da prestação do serviço é feita sem contemplar dos direitos trabalhistas e previdenciários ${ }^{369}$.

368 Celia Regina Camachi Stander em seu artigo já mencionado faz esta ponderação no sentido de ser necessário separar o "joio do trigo", identificando-se o que constitui a fraude por meio de Cooperativa de Trabalho e constituição de Pessoa Jurídica, a fim de separar isto das condutas lícitas possíveis em termos de cooperativismo e prestação de serviços autônoma de fato (Op. cit., p. 105). A contratação de trabalhadores por meio de pessoas jurídica pode ser utilizada quando não presentes os requisitos da relação empregatícia (CARELLI, Rodrigo de Lacerda. Formas atípicas de trabalho. $2^{\mathrm{a}}$ ed. São Paulo: Ltr, 2010, p. 143)

369 KREIN, Jose Darin, PRONI, Marcelo Weishaupt. Economia informal: aspectos conceituais e teóricos. Série Trabalho Decente no Brasil. Documento de trabalho n.4, Escritório da OIT no Brasil. - Brasilia: OIT, 2010, 23 p. 230, disponível $\quad$ em http://www.oit.org.br/sites/default/files/topic/employment/pub/economia informal_241.pdf , acesso 28.04.2012. Os autores sugerem que esta "nova informalidade" advém do processo de reorganização econômica e de redefinição do papel da regulação do trabalho, com implicações significativas na 
Portanto, a constituição de pessoa jurídica, quando encobre uma relação de emprego, pode ser considerada expressão desta nova informalidade ${ }^{370}$, uma vez que esta se refere à conjuntura moderna de alteração das relações de trabalho em detrimento à contratação formal empregatícia. Esta nova face da informalidade envolve profissionais de elevada qualificação, ao contrário dos antigos informais caracterizados pela baixa renda, pouca qualificação e pequena produtividade ${ }^{371}$.

Marcus de Oliveira Kaufmann chama de "desresponsabilização do capital" o processo em que as empresas periféricas, não tendo condições de manter elevadas cifras de produção em face da competitividade exacerbada, contratam na informalidade, muitas vezes exigindo que o trabalhador se transforme em uma empresa unipessoal, fomentando o trabalho autônomo ${ }^{372}$.

Joana Nunes Vicente coloca que a escolha e o tratamento formal da relação como trabalho autônomo, quando mascaram uma relação de trabalho subordinado constituem uma "evasão fraudulenta" à disciplina do contrato de trabalho. Opera-se uma "deslaboralização" do vínculo laboral apenas no aspecto formal (e não substacial) visando a desresponsabilização do empregador ${ }^{373}$.

A expressão "pejotização" corresponde a um neologismo originado de "PJ", sigla para o termo "pessoa jurídica"374. Através dela, o empregador exige do trabalhador a constituição de uma pessoa jurídica (empresa individual) para sua admissão ou permanência no emprego, formalizando um contrato de natureza civil ou comercial, não obstante a prestação de serviços revelar-se como tipica relação empregatícia ${ }^{375}$. Esta

estruturação do mercado de trabalho e das políticas de proteção social. Trata-se de um fenômeno resultante tanto das restrições impostas pelo baixo crescimento econômico ao longo de extensos períodos, com geração de número de postos de trabalho insuficientes, quanto de uma redefinição de formas de contratação por parte das empresas. A "velha informalidade" inclui pessoas inseridas em atividades de sobrevivência, de baixa produtividade e desprotegidas do ponto de vista social e dos direitos fundamentais do trabalho.

370 KREIN, Jose Darin, PRONI, Marcelo Weishaupt. Op. cit, p. 28. Ao lado da "fraude da pejotização", referidos autores colocam como expressão da "nova informalidade" as falsas cooperativas, o trabalho informal em domicílio, relação de emprego triangular, falsos voluntários do terceiro setor, trabalho estágio que se caracteriza pela substituição de um profissional, autônomo proletarizado, contratação por prazo ou tempo determinado, práticas que encobrem uma relação de emprego.

371 CHAPPER, Alexei Almeida. Op. cit, p. 201-202.

372 Op. cit., p. 7.

373 Op. cit., p. 15.

374 STANDER, Celia Regina Camachi. Op. cit., p. 105.

375 SANTOS, Ronaldo Lima dos. Op. cit., p. 98. Neste mesmo sentido, MOREIRA, Adriano Jannuzzi. Pejotização e parassubordinação: o Direito do Trabalho frente a esta nova realidade e os passivos trabalhistas, previdenciários pela caracterização da relação de emprego. In Revista Síntese Trabalhista e 
exigência envolve, frequentemente, empregados mais qualificados e que percebem salários maiores, sob o argumento de que, com a redução dos impostos e encargos, poderá ser pago um salário maior. Relatam-se, inclusive, casos em que o empregado compra uma nota fiscal de uma terceira empresa para apresentar ao empregador, mediante o recebimento da remuneração ${ }^{376}$.

Portanto, o empregado é compelido a constituir uma empresa de fachada, não raro formada por única pessoa física ${ }^{377}$, seja para dar início à prestação de serviços, seja para continuar a realizar as mesmas funções que desempenhava na exempregadora (não se pode desconsiderar o fato de que em certas situações o próprio trabalhador manifesta sua preferência por esta forma de contratação visando pagar menos impostos) ${ }^{378}$.

\begin{abstract}
“A pejotização consiste em prática empresarial na qual o empregador busca os serviços de um trabalhador que possua firma estabelecida ou então exige que ele constitua pessoa jurídica, a fim de descaracterizar a relação de emprego para eximir-se das obrigações trabalhistas, previdenciárias e tributárias ${ }^{\prime 379}$.
\end{abstract}

A prática em estudo alcança os trabalhos intelectuais ${ }^{380}$ e, dentro deste Previdenciária, $\mathrm{n}^{\mathrm{0}}$ 291, ano XXIV, setembro de 2013, p. 06. Disponível em http://www.iob.com.br/bibliotecadigitalderevistas/bdr.dll?

$\mathrm{f}=$ templates\&fn=main.htm\&2.0. Acesso 18.09.2013.

376 Reportagem Pj é artificio para sonegação de direitos. In Revista Anamatra, ano XVII, n. $55,2^{\circ}$ semestre de 2008, p. 13-15. Disponível em http://ww1.anamatra.org.br/sites/1200/1223/00000743.pdf , acesso 05.05.2012.

377 Por se tratar de empresas sem empregados, apenas de fachada, a pejotização também é comumente chamada da empresa do "eu sozinho" (OLIVEIRA, Laura Machado de. Pejotização e Precarização das Relações de emprego. In Revista Sintese Trabalhista e Previdenciária, $\mathrm{n}^{\circ}$ 291, ano XXIV, setembro de 2013, p. 32. Disponível em http://www.iob.com.br/bibliotecadigitalderevistas/bdr.dll? $\mathrm{f}=$ templates\&fn=main.htm\&2.0. Acesso 18.09.2013).

378 SILVA, Wilma Nogueira de Araújo Vaz da. Comentários sobre algumas das fraudes recorrentes nas relações do trabalho. In Revista do Tribunal Regional do Trabalho da $2^{a}$ Região, n. 03, 2009, p.76.

379 ALVARENGA, Rúbia Zanotelli de. A pejotização como fraude à legislação trabalhista. In Revista Síntese Trabalhista e Previdenciária, $\mathrm{n}^{\circ}$ 291, ano XXIV, setembro de 2013, p. 1. Disponível em http://www.iob.com.br/bibliotecadigitalderevistas/bdr.dll? $\mathrm{f}=$-templates\&fn=main.htm\&2.0. $\quad$ Acesso 18.09.2013.

${ }^{380}$ CHAPPER, Alexei Almeida. Op. cit., p. 204. FILHO, Georgenor de Sousa Franco. O trabalho intelectual na era da informação: pejotização, blogs de consultas e contratos de imagem. In Revista de Direito do Trabalho, vol. 128, outubro 2007, p. 361. BELMONTE, Alexandre Agra. Pejotização, intermediação de venda de seguros, participação em blogs de consultas e opiniões e contratos de figuração avulsa- 
gênero, diversas categorias profissionais. Assim, pode ser identificada em vários setores econômicos e ramos de atividades, notadamente nas áreas hospitalares, informática ${ }^{381}$, indústria de entretenimento (cinemas, teatros, eventos) e veículos de comunicação ${ }^{382}$. Citase, ainda, a criação de pessoa jurídica por professores que ministram aulas em curso preparatórios para concurso público e exame da Ordem dos Advogados do Brasil (OAB) ${ }^{383}$.

A criação de uma pessoa jurídica é um meio de afastar um dos requisitos caracterizadores da relação de emprego, qual seja, a vinculação da figura do empregado a uma pessoa física ou natural (art. $3^{\circ}$, caput, da CLT) $)^{384}$.

Trata-se de uma imposição dos empresários destinada a reduzir o custo do trabalho pois, considerando uma escala decrescente, é maior no vínculo empregatício, seguido pelo autônomo, pelo cooperativado e, por fim, pela contratação de serviços prestados por empresa, ou seja, uma pessoa jurídica prestadora de serviços ${ }^{385}$.

Estamos diante, portanto, de uma forma de precarização das relações de trabalho, que traz consequências negativas tanto para aqueles que estão diretamente envolvidos como para o funcionamento do sistema de proteção social. Os trabalhadores contratados nessas condições contarão com uma proteção social reduzida (ainda que se filiem à Seguridade Social como contribuintes individuais, não terão direito à percepção do auxílio acidente, seguro desemprego; não haverá recolhimentos ao FGTS) além de não terem acesso aos direitos trabalhistas básicos (como pagamento de férias, décimo terceiro, horas extras). Por outro lado, temos a fragilização das fontes de financiamento das políticas sociais, especialmente, da seguridade social, ou seja, a não contribuição para a seguridade social e a menor arrecadação de impostos trazem prejuízos para as contas públicas,

algumas reflexões. IN Revista da Academia Nacional de Direito do Trabalho - o direito e o processo do trabalho em transformação e outros estudos, ano XV, n.15, 2007, p. 36.

381 Em reportagem do jornal Folha de São Paulo intitulada PJ é mais comum em remunerações altas, informa-se que nas áreas de engenharia, publicidade e tecnologia da informação tais práticas são frequentes (Jornal Folha de São Paulo, domingo, 08.04.2012, Caderno Emprego, p. 3)

382 SANTOS, Ronaldo Lima dos. Op. cit., p. 98.

383 PEREIRA, Leone. Op. cit., p. 120.

384 PEREIRA, Leone. Op. cit., p. 62; BARBATO, Maria Rosaria. Op. cit., p. 156; CHAPPER, Alexei Almeida. Op cit., p. 206; ALVES, Ivete Maria de Oliveira, TAVARES, Willian Deivid. O fenômeno da pejotização como consequência da precariedade das relações de trabalho. In Revista Síntese Trabalhista e Previdenciária, $\mathrm{n}^{\circ}$ 291, ano XXIV, setembro de 2013, p. 45. Disponível em http://www.iob.com.br/bibliotecadigitalderevistas/bdr.dll? $\mathrm{f}=$ templates\& $\mathrm{fn}=$ main.htm\&2.0. $\quad$ Acesso 18.09.2013.

385 RODRIGUES, Rodrigo Cândido. A pejotização da pessoa física, através da figura do microempresário individual: competência para julgamento. In Revista Trabalhista Direito e Processo, ano 10, n. 39, 2011, p. 188. 
dificultando a possibilidade de ampliação do sistema universal de proteção social ${ }^{386}$. Cabe notar, ainda, que o não recolhimento do FGTS prejudica a execução de projetos de habitação, saneamento básico e infra estrutura urbana, conforme disposto no artigo $9^{\circ}, \S 2^{\circ}$, da Lei 8036/90.

A vulnerabilidade se evidencia, também, no momento de rescisão contratual. O trabalhador contratado como pessoa jurídica, ao término da contratação, não recebe verbas rescisórias (como aviso prévio, férias vencidas, FGTS, multa por despedida arbitrária) e ainda arca com as despesas de encerramento da empresa ${ }^{387}$.

Outro efeito da fraude praticada contra o contrato de emprego está relacionado ao campo do direito coletivo do trabalho. Ao não ser reconhecido como empregado, o trabalhador perde sua identidade coletiva, pois passa a não mais se sentir integrante da categoria profissional. Isto gera, consequentemente, dificuldades para o sindicato articular a reivindicação de direitos. Soma-se, a isto, o desrespeito às normas de saúde e de segurança no trabalho ${ }^{388}$.

Do exposto, verifica-se não só uma mitigação dos valores trabalhistas, mas também dos princípios mais amplos consagrados pela Constituição Federal como o da dignidade da pessoa humana ${ }^{389}$, da justiça social e da valorização do trabalho.

O sucesso na competitividade entre as empresas não pode ser alcançado às custas da proteção do trabalhador, com o rebaixamento das condições de trabalho. $\mathrm{O}$

386 KREIN, Jose Darin, PRONI, Marcelo Weishaupt. Op. cit., p. 25-26. Segundo estes autores, o regime de PJ apresenta vantagens na transação de custos, de transformação da remuneração fixa em variável e, principalmente, de redução de todos os encargos sociais, trabalhistas e tributários. Os custos da empresa limitam-se ao pagamento e à gestão de um contrato comercial. Por esse expediente, as empresas economizam em torno de $60 \%$, considerando as contribuições sociais e os direitos trabalhistas (incluindo salário indireto e deferido). Os custos das diversas contribuições previdenciárias de um PJ, fora do sistema do Super-Simples, cai de 27,5\% (assalariado com carteira assinada) para $12 \%$ a 15\%. Ao mesmo tempo, o empresário tem espaço para reduzir a sua própria carga de impostos com lucro presumido, Pis/Cofins cumulativo e isenção de IR na distribuição de lucros, o que reduz custos e comprometimento da arrecadação tributária, especialmente das fontes de financiamento da seguridade social.

387 CARVALHO, Maria Amélia Lira de. Pejotização e descaracterização do contrato de emprego: o caso dos médicos em Salvador - Bahia. Dissertação apresentada ao Mestrado em Políticas Sociais e Cidadania da Universidade Católica de Salvador - USCAL, como requisito parcial para a obtenção do grau de Mestre, orientadora Profa. Dra. Ângela Maria Carvalho Borges, Salvador, 2010, p. 86-87. Disponível em http://tede.ucsal.br/tde arquivos/4/TDE-2010-10-22T124554Z-161/Publico/MARIA\%20AMELIA \%20LIRA\%20DE\%20CARVALHO.pdf . Acesso 13.06.2013.

388 STANDER, Celia Regina Camachi. Op. cit., p. 107.

389 OLIVEIRA, Laura Machado de. Op. cit., p. 26. 
trabalhador é um ser humano, portador de uma dignidade essencial que deve ser respeitada em qualquer circunstância. O homem não pode se tratado como um objeto e, por isso, em matéria de quantidade, de condições e de remuneração de trabalho existem limites intransponíveis que necessariamente devem ser respeitados ${ }^{390}$.

Tem-se, portanto, que a contratação de um trabalhador com as características de empregado, sem o devido reconhecimento jurídico do vínculo não pode ser vista como uma mera irregularidade formal. Consiste, ao invés, em uma grave ilegalidade por acarretar danos de natureza pessoal e, também, social uma vez que o Direito do Trabalho está ligado à sobrevivência do próprio modelo de sociedade ${ }^{391}$.

Referida conduta pode ser enquadrada criminalmente, já que o artigo 203, do Código Penal dispõe que "frustrar, mediante fraude ou violência, direito assegurado por legislação do trabalho" enseja uma "pena de detenção de um a dois anos e multa, além da pena correspondente à violência”. A completa tutela dos direitos trabalhistas não se restringe à aplicação do Direito Trabalhista, mas também envolve a aplicação de outros ramos do Direito, como o Penal. É importante ter a consciência de que, diante de uma fraude às leis trabalhistas, somente a condenação da empresa ao pagamento das verbas devidas pode não se mostrar suficiente para transformar a realidade social. Mas, ao contrário, a aplicação do Direito como um todo pode permitir o efetivo respeito aos direitos dos trabalhadores. O tipo penal ora estudado consuma-se quando o titular do direito assegurado pela legislação trabalhista não puder gozá-lo ou exercê-lo (crime material), em razão de fraude ou violência. Se a conduta reprimida afetar apenas interesses privados, envolvendo um ou alguns prejudicados determinados, caberá à Justiça Estadual a competência para julgar o crime. Por outro lado, caso a conduta provoque lesão a direitos de trabalhadores coletivamente considerados ou à organização geral do trabalho, o julgamento deverá ser realizado pela Justiça Federal ${ }^{392}$.

390 PLÁ RODRIGUES, Américo. Op. cit., p. 73-74.

391 MAIOR, Jorge Luiz Souto. A Supersubordinação. In RENAULT, Luiz Otávio Linhares [et al]. Parassubordinação: em homenagem ao Professor Márcio Túlio Viana. São Paulo: Ltr, 2011, p. 73

392 COSTA, Breno Ortiz Tavares, MOLARO, Rodrigo de Moraes. A aplicabilidade do art. 203 do Código Penal na seara trabalhista. In Revista do Tribunal Regional do Trabalho da $3^{a}$ Região, Belo Horizonte, v. 53, n. 83, jan/jun 2011, p. 27-28 e 31-32. Referidos autores apontam a existência de grandes empresas que adotam a violação das normas trabalhistas como expediente de redução dos custos da produção, fiando-se no fato de que nem todos os trabalhadores irão acionar a Justiça do Trabalho para pleitear seus direitos. "O cálculo é simples: de cada 100 trabalhadores dispensados, 50 ajuizarão reclamação 
No curso do processo trabalhista, o reconhecimento do vínculo empregatício é efetivado com base nos princípios norteadores do Direito do Trabalho, quais sejam, princípio da imperatividade das normas trabalhistas (uma vez presentes os requisitos do vínculo de empregado não cabe ao trabalhador excluir a aplicação das normas trabalhistas); princípio da irrenunciabilidade dos direitos trabalhistas (ao empregado é vedado privar-se das vantagens e proteções que lhe asseguram a ordem jurídica); princípio da primazia da realidade ${ }^{393}$.

Este último encontra sua fundamentação na boa fé, na dignidade da atividade humana e na desigualdade das partes. Ao se privilegiar a realidade dos fatos, valoriza-se o princípio da boa fé que inspira toda a ordem jurídica e se mostra ligado à ideia da justiça, já que a realidade reflete necessariamente a verdade. Por outro lado, as normas trabalhistas regulam a atividade humana e esta deve prevalecer sobre o elemento especulativo, uma vez que envolve a dignidade da pessoa humana. Embora o Direito do Trabalho possua mecanismos que visam diminuir as desigualdades econômica e cultural entre as partes contratantes, a possibilidade de abusos no plano individual ainda subsiste uma vez que o trabalhador, em razão de sua hipossuficiência, não tem condições de se impor perante o empregador ${ }^{394}$.

Ao se deparar com situação de fraude, a jurisprudência reconhece a relação empregatícia, conforme se depreende dos exemplos abaixo.

No processo $0000715-30.2012 .5 .07 .0025$, julgado pela $1^{\text {a }}$ Turma do Tribunal Regional do Trabalho da $7^{\mathrm{a}}$ Região (Relator: Emmanuel Teófilo Furtado), foi reconhecida a "manifesta investida fraudulenta da empresa cujo objetivo consistiu em baldar os direitos juslaborais da trabalhadora, com uso de uma capa de disfarce, a propaldada "pejotização", para encobrir a existência de vínculo de emprego". Com esta atitude empresarial, reconheceu-se a violação a dispositivos legais e constitucionais, tais como: art. $1^{\circ}$, inciso IV, da Constituição Federal, art. $9^{\circ}$, da CLT, arts. 421 e $1288, \S 1^{\circ}$, do

trabalhista; destes, 25 farão acordos pela metade do valor e para pagamento de forma parcelada. E nestes últimos 25 casos a empresa será condenada a pagar somente aquilo a que já estava obrigada no passado". Desta forma, concluem que a aplicação isolada das normas trabalhistas pode ensejar a fraude ou a inadimplência.

393 ALMEIDA, Bruno Carneiro da Cunha. O fenômeno da pejotização à luz dos princípios trabalhistas no contexto da flexibilização. In Revista da ESMAT 13, ano 4, n. 4, outubro de 2011, p. 66-68.

${ }^{394}$ PLA RODRIGUES, Américo. Op. cit., p. 359-362. 
CC. Além disso, a reclamada foi condenada ao pagamento de danos morais diante do desrespeito aos direitos da personalidade da trabalhadora hipossuficiente e à sua dignidade 395 .

A $4^{\mathrm{a}}$ Turma, do Tribunal Regional do Trabalho da $2^{\mathrm{a}}$ Região, no julgamento do processo 01162003620095020312 (Relator: Ricardo Artur Costa e Trigueiros, Revisor: Ivani Contini Bramante) reconheceu a fraude concretizada sob a roupagem de pessoa jurídica em relação a serviços prestados de forma pessoal e subordinada. No caso, necessitava a reclamada de um empregado típico, ou seja subordinado, que prestasse serviços de forma não eventual, pessoal e observando determinados horários. $\mathrm{O}$ trabalhador era subordinado ao diretor e ao sócio da empresa, na qual deveria comparecer todos os dias e registrar seus horários de entrada e saída no relógio de ponto. A prestação de serviços por meio de pessoa jurídica ou a emissão de notas fiscais não são suficientes para afastar a relação de emprego. Considerando que o pacto de trabalho é um contrato realidade, configurando-se a partir do desdobramento da realidade fática, restou reconhecido o vínculo de emprego ${ }^{396}$.

A ampliação da competência da Justiça do Trabalho para processar e julgar ações oriundas das relações de trabalho (art. 114, I, CF, com redação dada pela Emenda Constitucional 45/2004) permite que, na mesma ação trabalhista seja requerido o reconhecimento da nulidade de um contrato civil fraudulento com o pagamento das verbas trabalhistas e, sucessivamente, em caso de reconhecimento de validade deste contrato civil, sejam pagas as verbas típicas dele decorrentes ${ }^{397}$.

A pejotização é objeto de combate por parte das Superintendências Regionais do Trabalho. Ocorre que a atuação dos órgãos de fiscalização é pautada no pressuposto de existência de fraude, de uma forma generalizada. Embora, com efeito, exista uma tendência de utilização desta prática como meio de encobrir uma relação de emprego, conforme acima demonstrado, em diversas outras situações, esta forma de contratação atende aos interesses da empresa e do trabalhador. Nestes casos, o contrato firmado por meio de pessoa jurídica deve ser interpretado considerando as alterações das

${ }^{395}$ Disponível em http://www3.trt7.jus.br/consultajuris/documento.aspx?fv jidx=272118. Acesso 16.09.2013

${ }^{396}$ Disponível em http://www.trt2.jus.br/pesquisa-jurisprudencia-por-palavra-acordaos . Acesso 16.09.2013

${ }^{397}$ NETO, José Affonso Dallegrave. Op. cit., p. 246. 
relações de trabalho ${ }^{398}$. Na realidade, a fraude não pode ser presumida, mas provada, já que a empresa pode adotar a política que entender adequada considerando a livre iniciativa e a liberdade de exercício de qualquer atividade econômica (art. 170, da Constituição Federal $)^{399}$.

Importante colocar que, em razão de esta contratação de trabalhadores sob a forma de prestação de serviços ensejar a propositura de inúmeras ações trabalhistas que culminam com o reconhecimento da relação de emprego, algumas empresas vêm se valendo de outra prática para burlar a aplicação da legislação trabalhista denominada “CLT-flex" ou "CLT - cotas". Neste caso, a fraude consiste em registrar na Carteira de Trabalho apenas uma parte do salário do trabalhador, ao passo em que a outra parte (geralmente a maior) é paga através das chamadas "cotas-utilidades". Estas, por não apresentarem natureza salarial, estão isentas da incidência dos encargos trabalhistas (FGTS, férias, $13^{\circ}$ salário, horas extras etc), previdenciários e tributários. Há, portanto, evidente desvio de finalidade na concessão das utilidades, que não observam o disposto no art. $458, \S 2^{\circ}$, da $\operatorname{CLT}^{400}$.

As fraudes não podem ser vistas como um fenômeno isolado, pois assumem um papel importante e compõem todo um processo de desarticulação e de desmonte do Direito do Trabalho ${ }^{401}$.

Do exposto, é possível perceber que as práticas fraudulentas que visam burlar a legislação trabalhista são impulsionadas pelo desejo de aumento de lucro mediante redução de custos e são favorecidas pela situação de hipossuficiência do trabalhador. $\mathrm{Na}$ realidade, os valores em jogo, que para os empregadores representam custos, para os trabalhadores representam direitos essenciais para a sua sobrevivência e para o seu desenvolvimento como ser humano. Para a coletividade, representam a possibilidade de

398 BULGUERONI, Renata Orsi. Trabalho autônomo dependente: experiências italiana e espanhola e a realidade brasileira., Dissertação apresentada à banca examinadora da Faculdade de Direito da Universidade de São Paulo como exigência parcial para obtenção do título de Mestre em Direito do Trabalho e Seguridade Social. São Paulo, 2011, p. 206.

399 MARTINS, Sergio Pinto. Prestação de serviço por meio de pessoa jurídica e vínculo de emprego. In Suplemento de Legislação, jurisprudência e doutrina. Ano XXVII, no 07, julho 2008, p. 06.

400 VITORINO, Adriana. "CLT flex" - a nova modalidade de fraude. In Revista Ltr, ano 76, n 04, abril 2012, p. 463-467.

401 VIANA, Márcio Tulio. Fraude à lei em tempos de crise. In Revista do Tribunal Regional do Trabalho da $9^{a}$ Região, Curitiba, v 21, n. 2, jul/dez 1996, p. 70. 
integração do trabalhador na sociedade e de formação de um sistema de proteção social.

A fraude no âmbito trabalhista é dotada de grande nocividade na medida em que promove um desequilíbrio nas relações sociais, destrói a dignidade do trabalhador mediante a supressão de direitos que lhe são fundamentais e fomenta comportamentos cada vez mais diversificados que colocam em risco a estabilidade do sistema capitalista. Seu combate é fundamental para se manter a coesão social. Por outro lado, também é necessário saber distinguir a existência de outras relações de trabalho lícitas, que melhor se adequam às necessidades de uma empresa mais dinâmica e flexível, sob pena de gerar insegurança aos trabalhadores envolvidos. 


\section{CONCLUSÃo}

O surgimento e o desenvolvimento da legislação trabalhista ocorreram à luz do trabalho realizado nas grandes indústrias, caracterizado pela produção em massa, pela especialização das atividade, por uma rígida organização hierárquica e por contratos por tempo indeterminado. A crise econômica dos anos 70, o advento de novas tecnologias e a globalização promoveram alterações no sistema produtivo com significativa influência nas relações trabalhistas. Se por um lado houve o aumento do número de desempregados e do trabalho informal, por outro sentiu-se a necessidade de novas formas de contratação. A utilização do trabalho autônomo, da terceirização, de cooperativas, de contratos por prazo determinado ganhou relevância. Além disso, observou-se a expansão do setor terciário, a formação de novas profissões e o surgimento de profissionais cada vez mais qualificados.

As mudanças na realidade fática passaram a exigir das normas trabalhistas maior adaptabilidade. A doutrina passou a abordar a questão da flexibilidade das normas trabalhistas como sendo a adequação dos preceitos que regem as relações laborais às grandes alterações do mundo do trabalho desencadeadas pela globalização, pelas crises econômicas e pelo desenvolvimento tecnológico.

Trata-se de uma adaptação necessária para melhor sintetizar os interesses dos trabalhadores e do capital, o que não significa fuga ao Direito do Trabalho, desregulamentação ou precarização. Não se trata de abandonar todas as conquistas já efetivadas, mas de reanalisar o sistema protetivo considerando as novas formas de prestação de serviço. O grande desafio, atualmente, é alcançar uma redefinição das relações de trabalho, para que este ramo do Direito possa manter sua vocação de proteção aos hipossuficientes, sem que isto obste o desenvolvimento econômico.

Dentro deste contexto de adaptação das normas trabalhistas às novas realidades, passa-se a discutir seu âmbito de incidência. Tradicionalmente, o Direito do Trabalho voltou-se à proteção do empregado, entendido como o trabalhador subordinado, que desenvolve pessoalmente uma atividade, de forma habitual e mediante remuneração. $\mathrm{O}$ entendimento predominante é o de que a subordinação é um fenômeno jurídico na medida em que decorre do contrato estabelecido entre o empregado e o empregador, cabendo a este o direcionamento objetivo da realização da atividade. 
O Direito do Trabalho, portanto, se desenvolveu através separação entre trabalho autônomo e trabalho subordinado, tutelando apenas este último. Embora o trabalho subordinado continue sendo a principal forma de contratação, vem se observando o crescimento do trabalho autônomo em razão do novo modelo empresarial mais enxuto, competitivo e mais dinâmico. Além disso, consideram-se, também, a ausência de oportunidades de trabalho subordinado, as novas preferências empresariais por um trabalho flexível e a própria vontade de trabalhador de galgar maiores ganhos e de gerir sua própria atividade como elementos que fomentam o trabalho autônomo.

As novas maneiras de organização da produção são cada vez mais dependentes do conhecimento individual especializado, altamente qualificado, o que confere ao trabalhador maior liberdade no desenvolvimento de suas atividades. $\mathrm{O}$ trabalho autônomo envolve um universo amplo de atividades e, nos últimos tempos, se detectou uma nova forma de seu desenvolvimento que passou a ser denominada pelo legislador europeu como trabalho parassubordinado (Itália), pessoa assemelhada ao trabalhador subordinado (Alemanha - “employee-like person") ou trabalhador autônomo economicamente dependente (Espanha).

O conceito de trabalho parassubordinado surge na Itália e se relaciona a atividades desenvolvidas de forma colaborativa, continuativa, coordenada (por esta razão foram apelidadas de "co.co.co") e de forma prevalentemente pessoal. Corresponde a uma forma intermediária de prestação de serviços situada entre o trabalho subordinado e autônomo. Diversamente do que ocorre no trabalho subordinado, em que o trabalhador se insere, pessoalmente, na estrutura empresarial, no trabalho parassubordinado a atividade prestada se insere nos fins da empresa, ou seja, os resultados do trabalho desenvolvido atendem aos objetivos do contratante. O trabalhador parassubordinado não se submete aos poderes de comando e disciplinar do contratante, mantendo sua autonomia na gestão da atividade, não obstante receber orientações gerais sobre esta.

$\mathrm{Na}$ Espanha, fala-se em trabalhador autônomo economicamente dependente, já que um dos requisitos para sua caracterização é o fato de o trabalhador autônomo possuir uma dependência econômica de uma única ou principal empresa cliente.

O importante é notar que ambos os ordenamentos procuraram proteger estes trabalhadores juridicamente autônomos, que prestam serviços de uma maneira 
contínua, não eventual, com pessoalidade, sem subordinação e com uma dependência quase exclusiva de um único cliente. $\mathrm{Na}$ realidade, estas figuras são reconhecidas em um contexto de necessidade de redimensionamento das categorias destinatárias da tutela trabalhista em razão das alterações do mercado de trabalho e das organizações empresariais.

No Brasil, a legislação é silente a este respeito. O reconhecimento do trabalho parassubordinado e a extensão a este de alguns direitos trabalhistas e previdenciários seriam medidas que, além de promoverem um redimensionamento do Direito do Trabalho, possibilitariam a realização dos princípios da justiça social, da dignidade da pessoa humana e permitiriam a estes trabalhadores acesso ao trabalho decente. A omissão deste ramo do Direito que, atualmente, se volta apenas à tutela do trabalho subordinado, contribui para o aumento da informalidade e incentiva o uso indevido de certas figuras jurídicas. Ao proteger o trabalho coordenado, o Direito do Trabalho cumpre sua missão de promover inclusão social, de reduzir as desigualdades sociais.

Dentro desta perspectiva de redimensionamento do Direito do Trabalho, considera-se, de uma forma mais ampla, a possibilidade de tutela do trabalho autônomo (e não só o parassubordinado), ainda que de uma forma gradual, como maneira de permitir a todos os trabalhadores o acesso ao trabalho decente e digno.

O trabalho autônomo e parassubordinado, hoje excluídos da proteção trabalhista, podem ser desempenhados por uma pessoa física ou sob a forma de pessoa jurídica. Normalmente, profissionais de extrema especialização e conhecimento, no livre exercício de sua atividade, trabalham em regime de autonomia (ou parassubordinação) ou constituem empresas prestadoras de serviço. A criação de uma pessoa jurídica para o exercício de atividades intelectual é, em princípio, lícita, eis que amparada pelo princípio da livre iniciativa previsto no art. 170, caput, da CF. Geralmente, ocorre por razões tributárias, pelo fato de a atividade começar a prosperar exigindo uma organização melhor dos recursos ou até mesmo pelo fato de melhor atender às exigências do mercado por uma contratação mais flexível.

Diante da insegurança causada por inúmeras desconsiderações da pessoa jurídica promovidas por auditores fiscais visando o recolhimento de imposto de renda e das 
contribuições previdenciárias, como se os prestadores fossem pessoas físicas autônomas ou empregadas, foi editado o art. 129, da Lei 11.196/2005. Procurou-se, portanto, com este artigo, conceder segurança àqueles que constituem sociedade para o exercício de atividade intelectual. Mas uma segurança voltada notadamente ao campo tributário.

Importante notar que o artigo 129, da Lei 11.196/2005 acaba reconhecendo, em nosso ordenamento, ainda que de uma maneira não explícita, a figura do trabalhador economicamente dependente. Na realidade, a prestação de serviços intelectuais quase sempre se afasta da subordinação jurídica, pois tais atividades são fruto do espírito livre do prestador. Estes trabalhadores, em geral, preferem uma forma de contratação regida pela legislação civil, que permite maior liberdade na manifestação da vontade e que reflete as novas exigências decorrentes das alterações na forma de produção.

Embora tenha sido alvo de críticas, a Lei 11.196/2005 não pode ser considerada como promotora de uma fuga ao Direito do Trabalho, na medida em que incide sobre trabalhadores autônomos e parassubordinados, atualmente, excluídos de tutela trabalhista. No entanto, envolve uma realidade que vem exigindo uma releitura deste ramo do Direito.

O Direito do Trabalho poderia abranger tais situações caso houvesse uma regulamentação do trabalho parassubordinado e autônomo, com tutelas mínimas e graduadas. Assim, exemplificativamente no caso do trabalho parassubordinado, a pessoa física que, sem estrutura empresarial própria, estivesse vinculada ao objeto principal ou adjacente de uma empresa ou de um cliente poderia gozar de proteção legal como garantia a direitos fundamentais (quais sejam, livre escolha de profissão, liberdade de iniciativa, não discriminação); descanso semanal e feriados, descanso anual; indenização por perdas e danos em caso de rescisão injusta, entre outros ${ }^{402}$.

Com isso, o Direito do Trabalho ampliaria seu âmbito de incidência fazendo com que a constituição de uma pessoa jurídica ocorresse nos casos em que fosse realmente justificada pelo aumento dos negócios, pela necessidade de contratação de empregados, pela questão tributária mais vantajosa.

${ }^{402}$ ROBORTELLA, Luiz Carlos Amorim. A reconstrução do conceito de subordinação. In MANNRICH, Nelson [et al.]. Atualidades do direito do trabalho: Anais da Academia Nacional de Direito do Trabalho. São Paulo: Ltr, 2012, p. 273-274. A proteção mencionada encontra-se prevista na legislação espanhola para o trabalhador economicamente dependente, mas pode servir de referência para o desenvolvimento dos estudos no Brasil. 
Conclui-se, portanto, que a constituição de pessoa jurídica para o exercício de atividade intelectual, de natureza científica, literária ou artística é perfeitamente lícia, eis que fundamentada no princípio constitucional da livre inciativa que permite a escolha, pelos particulares, dos meios mais adequados para a realização de uma atividade econômica. Não se desconhece, entretanto, que, algumas vezes, este expediente pode ser utilizado para fraudar a aplicação da legislação trabalhista, o que exige a devida comprovação.

A fraude à relação de emprego pode ocorrer de inúmeras formas e uma das práticas que vem se destacando é a chamada "pejotização" (neologismo originado do termo pessoa jurídica). Através dela, o empregador exige que o trabalhador crie uma pessoa jurídica para sua admissão ou permanência no emprego formalizando, assim, um contrato de natureza civil ou comercial, não obstante, a prestação de serviços ocorrer como típica relação empregatícia. Geralmente, envolve trabalhadores intelectuais mais qualificados, que percebem salários maiores.

Trata-se de uma forma grave de precarização das relações de trabalho, na medida em que diminui o grau de proteção social dos trabalhadores. Através deste procedimento, frustram-se direitos fundamentais assegurados pela legislação trabalhista (como férias, pagamento de horas extras, décimo terceiro salário, recolhimento de FGTS etc), o que representa, também, ilícito tipificado penalmente (art. 203, do Código Penal). Não se pode esquecer das consequências à coletividade e ao sistema de seguridade social.

No caso da pejotização, o vínculo de emprego é reconhecido nas decisões jurisprudenciais considerando os princípios da primazia da realidade, da imperatividade das normas trabalhistas e o princípio da irrenunciabilidade dos direitos trabalhistas. A demonstração da fuga à relação de emprego prescinde da comprovação do consilium fraudis.

Embora se reconheça uma tendência de utilização da criação de uma pessoa jurídica para encobrir uma relação empregatícia, a fraude não pode ser presumida. Em diversas situações, esta forma de contratação atende aos ditames legais e está de acordo com os interesses da empresa e do trabalhador.

Importante considerar que ausência de registro do vínculo de emprego não decorre apenas da fraude, mas do não enquadramento da relação ao conceito de 
emprego, ante a ausência da subordinação típica ${ }^{403}$. Nestas situações, a interpretação do caso concreto deve considerar as alterações vivenciadas nas relações de trabalho já relatadas acima que demandam, cada vez mais, formas diferenciadas de prestação de serviço.

${ }^{403}$ MANNRICH, Nelson. Inderrogabilidade da norma trabalhista e indisponibilidade de direitos: algumas reflexões. In Revista da Academia Nacional de Direito do Trabalho - O Direito do Trabalho e a Crise Econômica e outros Estudos, ano XVII, n. 17, Editora Ltr, 2009, p. 82. 


\section{BIBLIOGRAFIA}

ALMEIDA, Bruno Carneiro da Cunha. O fenômeno da pejotização à luz dos princípios trabalhistas no contexto da flexibilização. In Revista da ESMAT 13, ano 4, n. 4, outubro de 2011.

ALVARENGA, Rúbia Zanotelli de. A pejotização como fraude à legislação trabalhista. In Revista Síntese Trabalhista e Previdenciária, n 291, ano XXIV, setembro de 2013, p. 1. Disponível em http://www.iob.com.br/bibliotecadigitalderevistas/bdr.dll?f=templates\&fn=main.htm\&2.0. Acesso 18.09.2013.

ANAN JUNIOR, Pedro. Comentários sobre o veto da Emenda 3, que alterava o art. 6 da Lei $n$ 10.592/2002, e as autuações fiscais das sociedades prestadoras de serviços. In ANAN JUNIOR, Pedro, PEIXOTO, Marcelo Magalhães (coordenadores). Prestação de serviços intelectuais por pessoas jurídicas: aspectos legais, econômicos e tributários. São Paulo: MP Ed, 2008.

ANAN JUNIOR, Pedro, PEIXOTO, Marcelo Magalhães. Apresentação da obra Empresa Individual de Responsabilidade Limitada - EIRELI: aspectos econômicos e legais. São Paulo: MP Ed., 2012.

ANTUNES, Ricardo. Os sentidos do trabalho, ensaio sobre a afirmação e negação do trabalho. 2a ed. São Paulo: Boitempo, 2009.

ALVES, Ivete Maria de Oliveira, TAVARES, Willian Deivid. O fenômeno da pejotização como consequência da precariedade das relações de trabalho. In Revista Síntese Trabalhista e Previdenciária, no 291, ano XXIV, setembro de 2013, p. 45. Disponível em http://www.iob.com.br/bibliotecadigitalderevistas/bdr.dll?f=templates\&fn=main.htm\&2.0.

Acesso 18.09.2013.

AZEVEDO, Erasmo Valladão e FRANÇA, Novaes. Sociedade que tem por objeto a prestação de serviços de natureza intelectual é de natureza simples, qualquer que seja a forma de sua organização. In Revista de Direito Mercantil, industrial, econômico e financeiro, n. 157, janeiro-março/2011, Malheiros Editores.

BARROS, Alice Monteiro de. Curso de Direito do Trabalho. $6^{\text {a }}$ ed. São Paulo: Ltr, 2010. Trabalhadores intelectuais: subordinação jurídica. Redimensiosamento. In Revista de direito do Trabalho, n. 115, ano 30, julho a setembro de 
2004, Editora Revista dos Tribunais.

BARROS, Cassio Mesquita. O futuro do direito do trabalho. In ZAINAGHI, Domingos Sávio, FREDIANI, Yone (coordenadores). Novos rumos do direito do trabalho na América Latina. São Paulo: Ltr, 2003.

BARROS, Juliana Augusta Medeiros de. O Trabalho Parassubordinado e o art. $7^{\circ}$, caput, da Constituição Federal de 1998. In RENAULT, Luiz Otávio [et al]. Parassubordinação: em homenagem ao Professor Márcio Túlio Viana. São Paulo: Ltr, 2011.

BARBATO, Maria Rosaria. La frode alla legge nel diritto del lavoro italiano e brasiliano. Dottorato di ricerca in autonomia individuale e autonomia colletiva, Universitá Degli Studi di Roma "Tor Vergata", 2008/2009. Disponível em http://dspace.uniroma2.it/dspace/bitstream/2108/1063/1/Tesi.pdf. Acesso 25.03.2013.

BATALHA, Elton Duarte. Necessidade de reforma trabalhista: a experiência italiana. In Revista de Direito de Trabalho, ano 34, n. 131, jul.-set./2008.

BELMONTE, Alexandre Agra. Pejotização, intermediação de venda de seguros, participação em blogs de consultas e opiniões e contratos de figuração avulsa-algumas reflexões. IN Revista da Academia Nacional de Direito do Trabalho - o direito e o processo do trabalho em transformação e outros estudos, ano XV, n.15, 2007.

BELTRAN, Ari Possidonio. Direito do Trabalho: crise econômica, flexibilização e desenvolvimento tecnológico. In Empresa e trabalho - estudos em homenagem a Amador Paes de Almeida. Saraiva, 2010.

. Dilemas do trabalho e do emprego na atualidade. São

Paulo: Ltr, 2001.

BICHARA, Luis Gustavo e OLIVEIRA, Wagner S. Barroso de. Anotações práticas sobre $o$ advento da EIRELI. In ANAN JUNIOR, Pedro, PEIXOTO, Marcelo Magalhães (coordenadores). Empresa Individual de Responsabilidade Limitada - EIRELI: aspectos econômicos e legais. São Paulo: MP Ed., 2012.

BOISSONNAT, Jean. 2015 - Horizontes do trabalho e do emprego. Relatório da Comissão presidida por Jean Boissonnat: traduzido por Edilson Alkimim Cunha. São Paulo: Ltr, 1998.

BORBA, José Edwaldo Tavares. Direito Societário. 9a . ed. Rio de Janeiro: Renovar, 2004. BORBA, Joselita Nepomuceno. Subordinação jurídica. Parassubordinação. Contrato de 
atividade: a busca de uma nova dogmática, para a relação de trabalho. In Revista de Direito do Trabalho, n. 116, ano 30, outubro - dezembro 2004.

BULGUERONI, Renata Orsi. Parassubordinção: origem, elementos, espécies e tutela. In Revista de Direito de Trabalho, ano 34, n. 131, jul.-set./2008.

. Trabalho autônomo dependente: experiências italiana $e$

espanhola e a realidade brasileira. Dissertação apresentada à banca examinadora da Faculdade de Direito da Universidade de São Paulo como exigência parcial para a obtenção do título de Mestre em Direito do Trabalho e Seguridade Social. São Paulo, 2011. CAHALI, YUSSEF SAID. Fraude contra credores, fraude à execução, ação revocatória falencial, fraude à execução fiscal, fraude à execução penal. $2^{\mathrm{a}}$. ed. São Paulo: Editora Revista dos Tribunais, 1999.

CARELLI, Rodrigo de Lacerda. Formas atípicas de trabalho. $2^{\mathrm{a}}$ ed. São Paulo: Ltr, 2010.

CARINCI, Franco, TAMAJO, Raffaele de Luca, TOSI, Paolo, TREU, Tiziano. Diritto del lavoro, il rapporto di lavoro subordinato. Sesta edizioni. UTET giuridica.

CARVAlHO, Maria Amélia Lira de. Pejotização e descaracterização do contrato de emprego: o caso dos médicos em Salvador - Bahia. Dissertação apresentada ao Mestrado em Políticas Sociais e Cidadania da Universidade Católica de Salvador - USCAL, como requisito parcial para a obtenção do grau de Mestre, orientadora Profa. Dra. Ângela Maria Carvalho Borges, Salvador, 2010. Disponível em http://tede.ucsal.br/tde arquivos/4/TDE-2010-1022T124554Z-161/Publico/MARIA\%20AMELIA\%20LIRA\%20DE\%20CARVALHO.pdf . Acesso 13.06.2013.

CAVALCANTE, Jouberto de Quadros Pessoa, JORGE NETO, Francisco Ferreira. Aspectos do artigo 129, da Lei 11.196. Da terceirização e do Direito do Trabalho in Revista do TRT da 15 Região, n. 27, jul/dez de 2005. Disponível em http://www.trt15.jus.br/escola_da_magistratura/Rev27Art10.pdf, acesso 26.02.2012.

CAVALCANTE, Marcos de Oliveira. Quais as atividades que podem ser exploradas por uma EIRELI (e quais as diferenças entre EIRELI - prestador de serviços - e empregado). In JUNIOR, Pedro Anan, PEIXOTO, Marcelo Magalhães (coordenadores). Empresa Individual de Responsabilidade Limitada - EIRELI: aspectos econômicos e legais. São Paulo: MP Ed., 2012.

CHAPPER, Alexei Almeida. A questão da pejotização e da informalidade. In Revista da 
Academia Nacional de Direito do Trabalho - O Direito do Trabalho e a crise econômica e outros estudos, ano XVII, n. 17, Editora Ltr, 2009.

COELHO, Fabio Ulhoa. Manual de direito comercial. 14 ${ }^{\mathrm{a}}$ ed. Rev. Atual. de acordo com o novo Código Civil e alterações da LSA e ampl. com estudo de comércio eletrônico. São Paulo: Saraiva, 2003.

Comissão das Comunidades Europeias. Livro verde - modernizar o direito do trabalho para enfrentar os desafios do século XXI. Bruxelas, 22.11.2006. Disponível no site http://eur-lex.europa.eu/LexUriServ/site/pt/com/2006/com2006_0708pt01.pdf, acesso 05.03.2013.

COSTA, Breno Ortiz Tavares, MOLARO, Rodrigo de Moraes. A aplicabilidade do art. 203 do Código Penal na seara trabalhista. In Revista do Tribunal Regional do Trabalho da $3^{a}$ Região, Belo Horizonte, v. 53, n. 83, jan/jun 2011.

CRICENTI, Giuseppe. I contratti in forde alla legge. Seconda Edizione. Milano: Giufrrè editore, 2008.

DELGADO, Gabriela Neves. Direito fundamental ao trabalho digno. São Paulo: Ltr, 2006. DELGADO, Mauricio Godinho. Curso de direito do trabalho. $5^{\mathrm{a}}$.ed.. São Paulo: Ltr, 2006. . Direitos fundamentais na relação de trabalho. In Revista Ltr, vol 70, nº6, junho de 2006.

DORNELLES, Francisco. Novas perspectivas para os empreendedores brasileiros. In ANAN JUNIOR, Pedro, PEIXOTO, Marcelo Magalhães (coordenadores). Empresa Individual de Responsabilidade Limitada - EIRELI: aspectos econômicos e legais. São Paulo: MP Ed., 2012.

FERNANDES, António Monteiro. Direito do Trabalho. 13a edição. Almedina, 2006.

FILHO, Edmar Oliveira Andrade. Análise estrutural e teleológica do enunciado do art. 129 da Lei 11.196/2005. In ANAN JUNIOR, Pedro, PEIXOTO, Marcelo Magalhães (coordenadores). Prestação de serviços intelectuais por pessoas jurídicas: aspectos legais, econômicos e tributários. São Paulo: MP Ed, 2008.

FILHO, Georgenor de Sousa Franco. O trabalho intelectual na era da informação: pejotização, blogs de consultas e contratos de imagem. In Revista de Direito do Trabalho, vol. 128, outubro 2007.

FILHO, Ives Gandra da Silva Martins. Exigências de um novo direito do trabalho. In MARTINS, Ives Gandra e CAMPOS, Diogo Leite de (coordenadores). $O$ direito 
contemporâneo em Portugal e no Brasil. São Paulo: Saraiva, 2004.

FILHO, José Claudio Monteiro de Brito. Trabalho decente: análise jurídica da exploração, trabalho forçado e outras formas de trabalho indigno. São Paulo: Ltr, 2004.

FREDIANI, Yone. A quem o Direito do Trabalho deve proteger e o novo conceito de subordinação. In FILHO, Jorge Cavalcanti Boucinhas, BERARDO, Carlos Francisco (organizadores). Novos dilemas do trabalho, do emprego e do processo do trabalho. São Paulo: Ltr, 2012.

FREITAS, Claudio Victor de Castro. A parassubordinação, contrato de trabalho a projeto e o direito brasileiro - uma análise das novas relações de trabalho sob uma ótica globalizada. In Revista Ltr, volume 73, n. 10, outubro de 2009.

GALANTINO, Luisa. Diritto del lavoro. 14ª ed. Torino: G. Giappichelli editore, 2006.

GARATTONI, Marina. Subordinazione, parassubordinazione e colaborazione coordinata e continuativa. Roma: Ediesse, 2003.

GARCÍA, Rosa María Morato. El reconocimento legal de la figura del trabajador autónomo económicamente dependiente em España. In Revista Complejus - AMATRA 21 - Associação dos Magistrados do Trabalho da 21 a Região, V. 1, N. 1, jan./jun. 2010. Disponível em http://www.amatra21.org.br/Revista\%5CRevista\%20Complejus.pdf, acesso 23.01.2012.

GASPARI, Alessandra. La qualificazione di un rapporto di lavoro controverso - le risposte passate e recenti, della dialettica autonomia/subordinazione alla sua metamorfosi in corso. In Lavoro e Previdenza oggi, ano 30, n. 03, Milano, março 2003.

GESTRI, Marco. Abuso del dirittto e frode alla legge nell'ordinamento comunitario. Milano: Giuffrè, Fott. A. Giufrrè Editore, 2003.

GOMES, Dinaura Godinho Pimentel. Direito do trabalho e dignidade da pessoa humana, no contexto da globalização econômica: problemas e perspectivas. São Paulo: Ltr, 2005.

GONÇALVES, Leandro Krebes. Os direitos constitucionais do trabalhador autônomo. Texto publicado no Caderno 14, da Anamatra IV, disponível no site http://www.amatra4.org.br/cadernos/264-caderno-14?start=2. Acesso 22.07.2013

GOSDAL, Thereza Cristina. Dignidade do trabalhador: um conceito construido sob o paradigma do trabalho decente e da honra. São Paulo: Ltr, 2007.

GOULARD, Rodrigo Fortunato. Trabalhador autônomo e contrato de emprego. Curitiba: 
Juruá, 2012.

HARADA, Kiyoshi. Super Receita. Veto à Emenda 3. Uma tremenda confusão mental. Disponível em http://jus.com.br/artigos/9793/super-receita-veto-a-emenda-3. Acesso 26.12.2013.

HERNÁNDEZ ALVAREZ, Oscar. La prestación de trabajo em condiciones de fraude o simulación. [S.I]:[S.n], 1989. Texto obtido na biblioteca do Tribunal Regional do Trabalho da $2^{\text {a }}$ Região.

HERRERO NIETO, Bernardino. La simulación y el fraude a la ley em el derecho del trabajo. Bosch, Barcelona: Casa Editorial, 1958.

JUNIOR, Humberto Theodoro. Fraude contra credores: a natureza da sentença pauliana. $2^{\mathrm{a}}$ ed. rev. atual. ampl. Belo Horizonte: Del Rey, 2001.

KAUfMANN, Marcus de Oliveira. Por uma nova dogmática do Direito do Trabalho: implosão e perspectivas. In Revista Ltr, vol. 70, $\mathrm{n}^{\circ}$ 02, fevereiro de 2006.

KREIN, Jose Darin, PRONI, Marcelo Weishaupt. Economia informal: aspectos conceituais e teóricos. Série Trabalho Decente no Brasil. Documento de trabalho n.4, Escritório da OIT no Brasil. - Brasilia: OIT, 2010, pp. 23-30, disponível em http://www.oit.org.br/sites/default/files/topic/employment/pub/economia_informal_241.pdf

KEMPEN, Otto Ernst, KRETZSCHMAR, Robert. Os problemas e as dificuldades de organizar sindicalmente os trabalhadores semiautônomos na Alemanha. In RENAULT, Luiz Otávio Linhares [et al]. Parassubordinação: em homenagem ao Professor Marcio Tulio Viana. São Paulo: Ltr, 2011.

LEMOS, Luciane Souza Soares de. Flexissegurança - aspectos gerais. In Revista trabalhista - Direito e processo, São Paulo, a . 9, n. 33, janeiro/março 2010.

LEONE, Gabriella. Le collaborazioni (coordinate e continuative) a progetto. In Rivista Giuridica del lavoro e della Previdenza Sociale, ano 55, n. 1, jan. Março 2004, Roma.

LEVI, Alberto. Distinzioni tra le relazioni di impiego e i contratti de prestazioni di servizi. Contratto atipici nel diritto italiano. In Revista de Direito do Trabalho, ano 33, n. 128, outdez. 2007.

LIMA, Alvino. A fraude no direito civil. São Paulo: Saraiva, 1965.

LIMA, Francisco Meton Marques de. A prestação de serviços sem vínculo de emprego Lei 11.195/2005: o retorno ao princípio da autonomia da vontade. In Revista do Tribunal Regional do Trabalho da 22 Região, Teresina, v. 4, n.1, jan/dez 2007. Disponível em 
http://portal.trt22.jus.br/site/arquivos/downloads/revista 2 54506.pdf\#page=64 , acesso 26.02.2012.

LIMA, Olavo Pinto. O trabalhador parassubordinado e a colaboração coordenada como novo critério diferenciados nas relações de trabalho. In Direitos Fundamentais e seus reflexos no mundo do trabalho, Tribunal Regional do Trabalho, 20a Região, UFES, 2007. MACHADO, Sidnei. A noção da subordinação jurídica: uma perspectiva reconstruída. São Paulo: Ltr, 2009.

MAIOR, Jorge Luiz Souto. A Supersubordinação. In RENAULT, Luiz Otávio Linhares [et al]. Parassubordinação: em homenagem ao Professor Márcio Túlio Viana. São Paulo, Ltr, 2011.

. Curso de direito do trabalho: teoria geral do direito do trabalho. Volume I. Parte I. São Paulo: Ltr, 2011.

- Relação de emprego e direito do trabalho: no contexto da ampliação da competência da Justiça do Trabalho. São Paulo: Ltr, 2007.

MANNRICH, Nelson. Relações de trabalho autônomo e subordinado: proposta para instituir critérios para sua distinção. In BRAMANTE, Ivani Contini, CALVO, Adriana (organizadores). Aspectos polêmicos e atuais do direito do trabalho. São Paulo: Ltr, 2007. . Distinções entre relação de emprego e contratos de prestação de serviços. Contratos atípicos no Direito Brasileiro e no Direito Comparado. In ANAN JUNIOR, Pedro, PEIXOTO, Marcelo Magalhães (coordenadores). Prestação de serviços intelectuais por pessoas jurídicas: aspectos legais, econômicos e tributários. São Paulo: MP Ed, 2008.

- Contratação de serviços intelectuais por meio de pessoa jurídica: mitos e realidades. In Revista do Advogado, ano XXVI, n. 86, julho de 2006. . Inderrogabilidade da norma trabalhista e indisponibilidade de direitos: algumas reflexões. In Revista da Academia Nacional de Direito do Trabalho - O Direito do Trabalho e a Crise Econômica e outros Estudos, , ano XVII, n. 17, Editora Ltr, 2009.

MARCONDES, Sylvio. Questões de direito mercantil. Saraiva, 1977.

MARKY, THOMAS. Curso elementar do direito romano. $8^{\mathrm{a}}$ ed.. São Paulo: Saraiva, 1995. MARTINEZ, Arturo. Flexibilização de normas e os novos rumos do direito do trabalho. In ZAINAGHI, Domingos Sávio; FREDIANI, Yone (coords). Novos rumos de direito do 
trabalho na América Latina. São Paulo: Ltr, 2003.

MARTINEZ, Pedro Romano. Exigências de um novo direito do trabalho. In MARTINS, Ives Gandra da Silva, CAMPOS, Diogo Leite de (coordenadores). $O$ direito contemporâneo em Portugal e no Brasil. São Paulo: Saraiva, 2004.

. Direito do trabalho, $4^{\mathrm{a}}$. ed, Coimbra, Almedina, 2007.

MARTINS, Ives Gandra da Silva. Lei 12.441 de 11.07.2011. In ANAN JUNIOR, Pedro, PEIXOTO, Marcelo Magalhães (coordenadores). Empresa Individual de Responsabilidade Limitada-EIRELI: aspectos econômicos e legais. São Paulo: MP Ed., 2012.

MARTINS, Sergio Pinto. Flexibilização das condições de trabalho. 4a .ed. São Paulo: Atlas, 2009.

Trabalhador autônomo. In Revista Ltr, vol 69, $\mathrm{n}^{\circ}$ 02, fevereiro de

2005.

. Direito do trabalho. $18^{\text {a }}$ ed. São Paulo: Atlas, 2003. . A terceirização e o Direito do Trabalho. $9^{\mathrm{a}}$ ed. Rev. e ampl. São

Paulo: Atlas, 2009.

. Prestação de serviço por meio de pessoa jurídica e vínculo de emprego. In Suplemento de Legislação, jurisprudência e doutrina. Ano XXVII, nº 07, julho 2008.

MENEZES, Cláudio Armando C. de. Os novos contornos das relações de trabalho e de emprego - Direito do Trabalho e a nova competência trabalhista estabelecido pela Emenda 45/04. In Revista Ltr, vol.69, nº 05, maio de 2005.

MERÇON, Paulo Gustavo de Amarante. Direito do Trabalho Novo. In Revista Ltr, vol. 75, $\mathrm{n}^{\mathrm{o}} 01$, janeiro de 2011.

. Além dos portões da fábrica - o Direito do

Trabalho em reconstrução. In Revista Ltr, vol. 71, n 10, outubro de 2007.

MONTEIRO, Manoel Ignácio Torres. A prestação de serviços artísticos, científicos e literários através da sociedade empresária. In ANAN JUNIOR, Pedro, PEIXOTO, Marcelo Magalhães (coordenadores). Prestação de serviços intelectuais por pessoas jurídicas: aspectos legais, econômicos e tributários. São Paulo: MP Ed, 2008.

MONTEIRO, Manoel Ignácio Torres; SOUZA, Glaucia Macedo de. Empresa Individual de Responsabilidade Limitada - aspectos gerais. In ANAN JUNIOR, Pedro, PEIXOTO, 
Marcelo Magalhães (coordenadores). Empresa Individual de Responsabilidade LimitadaEIRELI: aspectos econômicos e legais. São Paulo: MP Ed., 2012.

MONTEIRO, Washington de Barros. Curso de direito civil: direito das obrigações. Volume 5: $2^{\mathrm{a}}$ parte. $34^{\mathrm{a}}$. ed., rev. atual. por Carlos Alberto Dabus Maluf e Regina Beatriz Tavares da Silva. São Paulo: Saraiva, 2003.

. Curso de direito civil, parte geral. $35^{\mathrm{a}}$ ed. São

Paulo: Saraiva, 1997.

MORAIS, Alexandre de. Direito Constitucional. 15ª ed. São Paulo: Atlas, 2004.

MOREIRA, Adriano Jannuzzi. Pejotização e parassubordinação: o Direito do Trabalho frente a esta nova realidade e os passivos trabalhistas, previdenciários pela caracterização da relação de emprego. In Revista Síntese Trabalhista e Previdenciária, $\mathrm{n}^{\mathrm{o}}$ 291, ano XXIV, setembro de 2013, p. 06. Disponível em http://www.iob.com.br/bibliotecadigitalderevistas/bdr.dll?f=templates\&fn=main.htm\&2.0. Acesso 18.09.2013.

MORELLO, Umberto. Frode alla legge. Milano: Dott. A . Giuffrè Editore, 1969.

NAHAS, Tereza C.. Considerações a respeito da relação de trabalho - a questão do trabalho semidependente. In Revista Ltr, vol. 71, nº 09, setembro de 2007.

NASCIMENTO, Amauri Mascaro. Curso de direito do trabalho: história e teoria geral do direito do trabalho: relações individuais e coletivas do trabalho. $24^{\mathrm{a}}$ ed. rev. atual. e ampl. São Paulo: Saraiva, 2009. . Iniciação ao direito do trabalho. $26^{\mathrm{a}}$ ed. São Paulo:

Ltr, 2000.

NETO, Alfredo de Assis Gonçalves. A empresa individual de responsabilidade limitada. In Revista dos Tribunais, ano 101, vol 915, janeiro 2012.

NETO, José Affonso Dallegrave. A nova competência trabalhista para julgar ações oriundas da relação de trabalho. In Revista do TST, vol. 71, maio/agosto 2005. Disponível em http://www.tst.jus.br/web/biblioteca/2005-vol.-71 . Acesso 09.08.2013.

OLIVEIRA, Laura Machado de. Pejotização e Precarização das Relações de emprego. In Revista Síntese Trabalhista e Previdenciária, no 291, ano XXIV, setembro de 2013, p. 32. Disponível em http://www.iob.com.br/bibliotecadigitalderevistas/bdr.dll?f=templates\&fn=main.htm\&2.0. Acesso 18.09.2013 
OLIVEIRA, Murilo C. S. A ressignificação da dependência econômica. In Revista do TST, Brasília, Vol. 78, jan/mar 2012. Disponível em http://www.tst.jus.br/web/biblioteca/revista-do-tst . Acesso 15.08.2013. . Subordinação jurídica: um conceito desbotado. Texto extraído da Revista dos Tribunais on line, Thomson Reuters. Disponível em http://revistadostribunais.com.br/maf/app/delivery/document. Acesso 16.09.2013.

PALOMEQUE LÓPEZ, Manuel Carlos. Trabajo subordinado y trabajo autónomo em el ordinamiento laboral español. In Revista Gaceta Laboral, Maracaibo, Venezuela, vol 10., $\mathrm{n}^{\mathrm{o}} 01$, ene./abr. 2004.

PAROSKI, Mauro Vasni, FERREIRA, Cícero Pedro. Subordinação na relação de emprego e a necessidade de sua releitura nas sociedades contemporâneas. In Revista Ltr, vol. 76, $\mathrm{n}^{\circ}$ 05, maio 2012.

PASQUALIN, Roberto. A contratação de pessoa física como jurídica. In Revista de Direito Trabalhista, ano 12, $\mathrm{n}^{\circ}$ 02, fevereiro de 2006.

PEDRAZZOLI, Marcello. Il modo delle collaborazioni coordinate e continuative fra genuinità e frode. In Il diritto del lavoro. Roma: Fondazione Diritto del Lavoro, maggioagosto 2004, anno LXXVIII.

PEDREIRA, Pinho. Um novo critério de aplicação do direito do trabalho: a parassubordinação. In Revista de Direito do Trabalho, ano 27, n. 103, julho-setembro de 2001.

. Um novo modelo social: a flexissegurança. In Revista Ltr, vol 69, $\mathrm{n}^{\mathrm{o}}$

06, junho de 2005, p. 645.

PEREIRA, Leone. Pejotização: o trabalhador como pessoa jurídica. São Paulo: Saraiva, 2013.

PEREIRA, Regis Fichtner. Fraude à lei. Rio de Janeiro: Renovar, 1994.

PERES, Celia Mara. A contratação de pessoa jurídica e caracterização de vínculo empregatício. In JOÃO, Paulo Sergio, TEIXEIRA, Pedro Paulo. Temas em direito do trabalho: direito material individual. Vol. I, São Paulo: Ltr, 2008.

PEREZ, Julio Linuesa. EIRELI poderá diminuir informais em todo o Brasil. In Jornal Trabalhista Consulex, ano XXIX, n 1410, 23 janeiro de 2012.

PERULLI, Adalberto. Lavoro Autonomo e dipendenza economica, oggi. In Rivista 
Giuridica del lavoro e della Previdenza Sociale, anno LIV, 2003, n. 2, aprile/giugno 2003. PESSOA, Flavia Moreira Guimarães. Relações de trabalho na sociedade contemporânea. São Paulo: Ltr, 2009.

PLÁ RODRIGUES, Américo. Principios de direito do trabalho. Tradução de Wagner D. Giglio. $3^{\text {a }}$ ed., atual. São Paulo: Ltr, 2000.

PORTO, Lorena Vasconcelos. A subordinação no contrato de trabalho: uma releitura necessária. São Paulo: Ltr, 2009.

POSE, Carlos. Fraude y simulación em el derecho laboral. $1^{\mathrm{a}}$ ed., Buenos Aires: David Grinberg Libros Jurídicos, 2007.

PROSCURCIN, Pedro. O trabalho na reestruturação produtiva - análise jurídica dos impactos no posto de trabalho. São Paulo: Ltr, 2001.

. Do contrato de trabalho ao contrato de atividade: nova forma de regulação das atividades no mercado de trabalho. São Paulo: Ltr, 2003

PUGLIESE, Antonio. Riflessioni sul negozio in forde alla legge. In Rivista del Diritto Commerciale e del Diritto Generale delle obligazioni, Padova, v. 88, n. 3-4, mar/apr 1990, anno LXXXVIII.

QUEVEDO, Luiz Fernando Plens de. Trabalho como valor e a perspectiva de promoção do trabalho decente sob a ótica da OIT. Dissertação apresentada à Faculdade de Direito da Universidade de São Paulo, Departamento de Direito do Trabalho, como requisito para a obtenção do Título de Mestre. Orientador: Professor Nelson Mannrich. São Paulo, março de 2008.

RAMALHO, Maria do Rosário Palma. Ainda a crise do direito laboral: a erosão da relação de trabalho típica e o futuro do direito do trabalho. In Estudos de Direito do Trabalho. Volume I. Coimbra: Almedina, 2003. - Modernizar o Direito do Trabalho para o século XXI. Notas breves sobre o Livro Verde da Comissão Europeia, de 22 de novembro de 2006, e sobre os desafios da flexisegurança. In NAHAS, Thereza Christina (coordenadora). Princípios de direito e processo do trabalho: questões atuais. Rio de Janeiro, Campus: Elsevier, 2009.

Da autonomia dogmática do Direito do Trabalho.

Coimbra: Almedina, 2001. 
Recomendação 198, da OIT, sobre a relação de trabalho, de 15 de junho de 2006. Disponível em http://www.ilo.org/ilolex/cgi-lex/convds.pl?R198\#Link , acesso 19.02.2012.

REDINHA, Maria Regina Gomes. A relação laboral fragmentada - estudo sobre o trabalho temporário. Boletim da Faculdade de Direito da Universidade de Coimbra. Coimbra editora, 1995.

REPORTAGEM: Um país de empreendedores extraída da Revista Exame, edição 1012, ano $46, \mathrm{n}^{\circ} 05,21.03 .2012$.

REPORTAGEM Pj é artificio para sonegação e direitos. In Revista Anamatra, ano XVII, n. $55, \quad 2^{\circ}$ semestre de 2008, pp. 13-15. Disponível em http://ww1.anamatra.org.br/sites/1200/1223/00000743.pdf , acesso 05.05.2012.

REPORTAGEM PJ é mais comum em remunerações altas. Jornal Folha de São Paulo, domingo, 08.04.2012, Caderno Emprego, p. 3.

REPORTAGEM: Com 16 milhões de empresas, Brasil tem um novo negócio a cada 05 minutos. Disponível em http://economia.ig.com.br/empresas/2013-10-17/com-16-milhoes-de-empresasbrasil-tem-um-novo-negocio-a-cada-5-minutos.html . Acesso 30.10.2013.

REZENDE FILHO, Tabajara Medeiros de. Do protecionismo do empregado à proteção do trabalhador: desafios da flexicurity. Tese de Doutorado em Direito do Trabalho apresentada na Faculdade de Direito da Universidade de São Paulo. Orientador: Prof. Nelson Mannrich. São Paulo, 2013.

RIBEIRO, Ricardo Lodi. A natureza interpretativa do art. 129 da Lei 11.196/2005 e o combate à elisão abusiva na prestação de serviços de natureza científica, artística e cultural. In ANAN JR, Pedro, PEIXOTO, Marcelo Magalhães (coordenadores). Prestação de serviços intelectuais por pessoas jurídicas: aspectos legais, econômicos e tributários. São Paulo: MP Ed, 2008.

ROBORTELLA, Luis Carlos Amorim. A reconstrução do conceito de subordinação. In MANNRICH, Nelson [et al.]. Atualidades do direito do trabalho: Anais da Academia Nacional de Direito do Trabalho. São Paulo: Ltr, 2012.

ROBORTELlA, Luis Carlos Amorim, PERES, Antonio Galvão. Novas tendências do mercado de trabalho: Crise do trabalho subordinado, crescimento do trabalho autônomo $e$ de pessoas jurídicas. In ANAN JR., Pedro e PEIXOTO, Marcelo Magalhães, coordenadores. Prestação de serviços intelectuais por pessoas jurídicas: aspectos legais, 
econômicos e tributários. São Paulo: MP Ed, 2008.

RODRIGUES, Rodrigo Cândido. A pejotização da pessoa física, através da figura do microempresário individual: competência para julgamento. In Revista Trabalhista Direito e Processo, ano 10, n. 39, 2011.

ROMITA, Arion Sayão. A crise do critério da subordinação jurídica - necessidade de proteção a trabalhadores autônomos e parassubordinados. In Revista de Direito do Trabalho, ano 31, n. 117, janeiro-março de 2005, coordenador Nelson Mannrich. . Flexigurança: a reforma do mercado de trabalho. São Paulo:

Ltr, 2008.

SALOMO, Jorge Lages. A nova realidade da prestação de serviço. In Questões controvertidas no novo Código Civil, São Paulo, Editora Método, 2003.

SANTORO-PASSARELLI, Giuseppe. Globalizzazione e lavoro subordinato. In Roma e America. Diritto Romano Comune, Rivista di Diritto dell'Integrazione e Unificazione del Diritto in Europa e in America Latina, Roma, Itália, n. 15, 2003.

. Diritto dei Lavori. Seconda edizione. Torino: G. Giappichelli,

2004.

SANTOS, Ronaldo Lima dos. Fraudes nas relações de trabalho: morfologia e transcendência. In Revista do Tribunal Regional do Trabalho da $2^{a}$ Região, n. 03, 2009.

SARLET, Ingo Wolfgang. As dimensões da dignidade: construindo uma compreensão jurídico-constitucional necessária e possível. In SARLET, Ingo Wolfgang, ALEIXO, Pedro Scherer de Melo, ZANINI, Rita Dostal (organizadores). Dimensões da dignidade: ensaios de Filosofia do Direito e Direito constitucional. Porto Alegre: Livraria do Advogado Editora, 2005.

SCHWARZ, Rodrigo Garcia. A política europeia de emprego e a ideia de "flexissegurança": um novo paradigma para a "modernização" do direito do trabalho. In Revista do Tribunal Regional do Trabalho da $3^{a}$ Região, Belo Horizonte, v. 48, n. 78, jul/dez. 2008.

SCOGNAMIGLIO, Renato. Diritto del lavoro. Napoli: Casa Editrice Dott. Eugenio Jovene, 2000.

SILVA, De Plácido e. Vocabulário Jurídico. 15ª edição. Rio de Janeiro, 1998.

SILVA, José Afonso da. Curso de Direitos Constitucional Positivo. $16^{\text {a }}$ edição. São Paulo: 
Malheiros Editores, 1999.

SILVA, Homero Batista Mateus da. Curso de direito do trabalho aplicado. Vol 1: Parte Geral. Rio de Janeiro: Elsevier, 2009.

SILVA, Otavio Pinto e. Subordinação, autonomia e parassubordinação nas relações de trabalho. São Paulo: LTr, 2004.

. A função do Direito do Trabalho no mundo atual. In CORREIA,

Marcus Orione Gonçalves (organizador). Curso de Direito do Trabalho - Teoria Geral do Direito do Trabalho. Volume I. Ltr, 2007-2008.

. As relações de trabalho e a nova competência da Justiça do Trabalho. In Revista do TST, Brasília, vol. 71, n², maio/agosto 2005.

- A construção da concepção tricotômica: autonomia, subordinação e parassubordinação. In FILHO, Jorge Cavalcanti Boucinhas e BERARDO, Carlos Francisco (organizadores). Novos dilemas do trabalho, do emprego e do processo do trabalho. São Paulo: Ltr, 2012.

SILVA, Walküre Lopes Ribeiro da. Crise de representatividade e participação dos sindicatos em políticas ativas de emprego. Tese apresentada para concurso de Professor Titular de Direito do Trabalho da Faculdade de Direito da Universidade de São Paulo. São Paulo, 2001.

SILVA, Wilma Nogueira de Araújo Vaz da. Comentários sobre algumas das fraudes recorrentes nas relações do trabalho. In Revista do Tribunal Regional do Trabalho da $2^{a}$ Região, n. 03, 2009.

SOUSA, Taysa Queiroz Mota de. Flexissegurança e sua influência no Brasil. In Revista da ESMAT 13, ano 4, n 4, outubro de 2011.

STANDER, Celia Regina Camachi. Fraude por meio de coopertativa e de constituição de pessoa jurídica por trabalhadores. In Revista da Escola da Magistratura do Tribunal Regional do Trabalho da $2^{a}$ Região, São Paulo, ano I, n. 1, setembro de 2006, pp. 106. Disponível em $\quad$ http://www.trtsp.jus.br/html/tribunal/magistratura/pdfs/revista1.pdf. Acesso 25.04.2012.

SUPIOT, Alain. Transformaciones del trabajo y porvenir del derecho laboral en Europa. In Revista Internacional del trabalho, vol. 118, n 1, Ginebra, 1999.

SÜSSEKIND, Arnaldo [et al.]. Instituições de Direito do Trabalho. Volume I. 22a.ed.. 
atual. São Paulo: Ltr, 2005.

SUSSEKIND, Arnaldo. Da relação de trabalho. In Revista Ltr, vol. 74, n. 03, março de 2010.

SZTAJN, Rachel. Notas sobre o conceito de empresário e empresa no Código Civil Brasileiro. Texto extraído da Revista dos Tribunais on line, Thomson Reuters.

TEPEDINO, Gustavo. Sociedade prestadora de serviços intelectuais: qualificação das atividades privadas no âmbito do direito tributário. In ANAN JUNIOR, Pedro, PEIXOTO, Marcelo Magalhães (coordenadores). Prestação de serviços intelectuais por pessoas jurídicas: aspectos legais, econômicos e tributários. São Paulo: MP Ed, 2008.

URIARTE, Oscar Ermida, ALVAREZ, Oscar Hernández. Apuntes sobre los cuestionamientos al concepto de subordinación. In Revista de Direito do Trabalho, n. 103, ano 27, julho-setembro de 2001, Editora Revista dos Tribunais.

VENOSA, Silvio de Salvo. Direito Civil: parte geral. 3a . ed. São Paulo: Atlas, 2003.

VIANA, Márcio Túlio. Relações de trabalho e competência: esboço de alguns critérios. In Revista Ltr, volume 69, n. 06, junho de 2005.

- Trabalhadores Parassubordinados: Deslizando para fora do

Direito. In RENAULT, Luiz Otávio [et al]. Parassubordinação: em homenagem ao Professor Márcio Túlio Viana. São Paulo, Ltr, 2011.

Fraude à lei em tempos de crise. In Revista do Tribunal Regional do Trabalho da $9^{a}$ Região, Curitiba, v 21, n. 2, jul/dez 1996.

VICENTE, Joana Nunes. A fuga à relação de trabalho (típica) em torno da simulação e da fraude à lei. Coimbra editora, 2008.

VILHENA, Paulo Emilio Ribeiro de. Relação de emprego: estrutura legal e supostos. $3^{\mathrm{a}}$ ed. São Paulo: Ltr, 2005.

VITORINO, Adriana. “CLT flex” - a nova modalidade de fraude. In Revista Ltr, ano 76, $\mathrm{n}^{\circ}$ 04, abril 2012.

WEISS, Manfred. The evolution of the concept of subordination: the german experience. Aracaju: Evocati Revista n. 21 Disponível em: < http://www.evocati.com.br/evocati/artigos.wsp?tmp_codartigo=150 >. Acesso em: 28/02/2012. 